Review

\title{
Carotenoids and Markers of Oxidative Stress in Human Observational Studies and Intervention Trials: Implications for Chronic Diseases
}

\author{
Torsten Bohn $(\mathbb{D}$ \\ Department of Population Health, Luxembourg Institute of Health, L-1445 Strassen, Luxembourg; \\ torsten.bohn@gmx.ch
}

Received: 30 May 2019; Accepted: 14 June 2019; Published: 17 June 2019

\begin{abstract}
Carotenoids include C30, C40 and C50 terpenoid-based molecules, many of which constitute coloured pigments. However, $>1100$ of these are known to occur in nature and only about a dozen are known to play a role in our daily diet. Carotenoids have received much attention due to their proposed health benefits, including reducing the incidence of chronic diseases, such as cardiovascular disease and diabetes. Many of these diseases are characterized by chronic inflammation co-occurring with oxidative stress, characterized by, for example, enhanced plasma F2-isoprostane concentrations, malondialdehyde, and 8-hydroxyguanosine. Though carotenoids can act as direct antioxidants, quenching, for example, singlet oxygen and peroxide radicals, an important biological function appears to rest also in the activation of the body's own antioxidant defence system, related to superoxide-dismutase, catalase, and glutathione-peroxidase expression, likely due to the interaction with transcription factors, such as nuclear-factor erythroid 2-related factor 2 (Nrf-2). Though mostly based on small-scale and observational studies which do not allow for drawing conclusions regarding causality, several supplementation trials with isolated carotenoids or food items suggest positive health effects. However, negative effects have also been reported, especially regarding beta-carotene for smokers. This review is aimed at summarizing the results from human observational studies/intervention trials targeting carotenoids in relation to chronic diseases characterized by oxidative stress and markers thereof.
\end{abstract}

Keywords: carotenes; xanthophylls; beta-carotene; lycopene; cardio-metabolic diseases; tissue concentrations; metabolites; nuclear factors; transcription factors; cytokines; biomarkers; humans

\section{Introduction}

Carotenoids are terpenoid-based compounds produced by most plants and a variety of bacteria and fungi. Though C-40-based tetraterpenoid compounds constitute the majority of carotenoids, also a number of C-30-based carotenoids [1-3] and C-50-structured carotenoids [4-7] have been reported in several bacteria and archaea. Of the presently known 1100 carotenoids [2], only about a dozen play a significant role in the human diet. These include a couple of carotenes (lacking oxygen in the molecule) such as beta-carotene and several xanthophylls (containing oxygen within the molecule, Table 1), such as lutein.

Carotenoids are among the most frequently consumed liposoluble secondary plant compounds or phytochemicals, with an intake of several $\mathrm{mg} / \mathrm{d}$ [8]. Though compared to polyphenols, their intake is about 100 times lower; typical concentrations of around $0.9-2.5 \mu \mathrm{M}$ for total plasma carotenoids [8] range higher than those of native polyphenols [9], as they are less heavily metabolized. Carotenoids are mostly recognized for their vitamin A activity, as some can be cleaved in vivo via beta-carotene oxygenase 1 (BCO1) into vitamin A active compounds. In addition, carotenoids have shown to act, 
at least in vitro, as antioxidants, with a high potential to quench liposoluble radicals, as well as singlet oxygen [10], though their importance to act as direct antioxidant quenchers in vivo has, to some extent, been questioned [11,12]. An alternative pathway rests in the ability of carotenoids, and more likely their metabolites, to interact with nuclear receptors RAR/RXR (retinoic acid receptor/retinoid X receptor) or RAR/PPARs (RAR/peroxisome proliferator-activated receptors) to enhance immune-related functions [13] and to reduce adipocyte differentiation [14], respectively. In addition, it has been proposed that, especially, the more polar, i.e., cytosolic soluble and electrophilic metabolites, are able to interact with NF-kB (nuclear factor kappa B) and Nrf-2 (nuclear factor erythroid 2-related factor 2). This would inhibit translocation of NF-kB to the nucleus and lower inflammatory gene expression, resulting in decreased levels of certain cytokines such as tumour necrosis factor alpha (TNF- $\alpha$ ) ([15-17]; or fostering the translocation of Nrf-2 to the nucleus, stimulating the expression of antioxidant active enzymes such as catalase (CAT) and superoxide dismutase (SOD) [13,16-18], perhaps contributing to the lowering of markers of lipid peroxidation/oxidative stress such as malondialdehyde (MDA) and F2-isoprostane concentrations.

It is, thus, assumed that measuring such markers offers a suitable and early possibility to assess the risk of developing certain, especially chronic, cardiometabolic diseases. However, the validity of these markers is still controversially discussed and findings from observational studies or intervention trials focussing on the relation of carotenoids to diseases and disease markers have included a number of diverse - and mostly surrogate endpoints-encompassing different groups of subjects and study designs, with results often being difficult to compare across studies. Nevertheless, several observational human studies have related higher dietary intake or plasma concentrations of carotenoids with a decreased risk of developing several chronic diseases. For example, elderly subjects with higher circulating concentrations of plasma carotene ( $0.4 \mu \mathrm{M}$ higher than lower group) had an approximately 30\% lower all-cause mortality risk than subjects with low amounts [19]. Similarly, in a recent meta-analysis of circulating carotenoids, subjects with higher amounts of carotenoids were more protected (by approximately 40\%) from developing metabolic syndrome than subjects with lower plasma/serum levels [20]. These and similar findings have resulted in proposing a carotenoid health index [21], suggesting that subjects are at high risk $<1 \mu \mathrm{M}$ circulating total carotenoids, and that concentrations $>2.5 \mu \mathrm{M}$ for low risk should be targeted. This is already above concentrations in most subjects following a Westernized diet, for instance above the 95th percentile of the US population (circa $2.1 \mu \mathrm{M}$, [22]). Similarly, a recent paper by the EU-COST action EUROCAROTEN concludes that most subjects consume around a total of $11.8 \pm 4.2 \mathrm{mg}$ carotenoids per day, resulting in $1.73 \pm 0.38 \mu \mathrm{M}$ circulating total carotenoids, which may still be sub-optimal [8].

However, contrary to most observational studies, negative effects following carotenoid supplementation in conjunction with high levels of circulating carotenoids in intervention trials have also been highlighted. These appear to be limited to subjects with defect lung function such as smokers [23,24] and asbestos-exposed subjects [25], following the intake of high doses of beta-carotene, resulting in plasma beta-carotene concentrations of about 10 times their baseline concentration [26], which may be outside the normal physiological range. Though such negative effects, possibly involving the upregulation of cytochrome-P450 and the formation of pro-cancerous intermediate compounds [27] should not be overlooked, as such supplementations do not reflect normal dietary behaviour from a varied and mixed diet.

This review aimed to critically assess the strength of evidence between carotenoid intake and changes in oxidative stress and in part inflammation-related markers in human observational studies as well as intervention trials and associated diseases in healthy and diseased subjects, trying to highlight the diversity of findings, differences found between studies investigating supplemental carotenoids and carotenoids in food items, and mechanistic aspects related to the various markers employed. Though the focus of this review rests on oxidative stress, as inflammation and oxidative stress are intertwined, one aggravating the other [28], some selected inflammatory aspects will also be discussed briefly. 
Table 1. Common carotenoids in our diet, their intake, and plasma concentrations ${ }^{\varsigma}$.

\begin{tabular}{|c|c|c|c|c|c|}
\hline Name & Chemical Formula & Found in & $\begin{array}{l}\text { Typical Conc. in Food } \\
(\mu \mathrm{g} / \mathbf{1 0 0} \mathrm{g})\end{array}$ & Dietary Intake $^{£}(\mathrm{mg} / \mathrm{d})$ & Conc. in Plasma/Serum ${ }^{£}(\mu \mathrm{M})$ \\
\hline Beta-carotene & $\mathrm{C}_{40} \mathrm{H}_{56}$ & $\begin{array}{c}\text { carrots } \\
\text { leafy vegetables (spinach) } \\
\text { sweet potatoes } \\
\text { pumpkin } \\
\text { broccoli }\end{array}$ & $\begin{array}{c}8285 \pm 1082[29] \\
5626 \pm 766[29] \\
5219[29] \\
3100[29] \\
361 \pm 7[29]\end{array}$ & $4.1 \pm 1.7$ & $0.50 \pm 0.14$ \\
\hline Alpha-carotene & $\mathrm{C}_{40} \mathrm{H}_{56}$ & $\begin{array}{c}\text { carrots } \\
\text { leafy vegetables (spinach) } \\
\text { sweet potatoes } \\
\text { pumpkin } \\
\text { broccoli }\end{array}$ & $\begin{array}{c}3477 \pm 531[29] \\
4016[29] \\
25 \pm 3[29]\end{array}$ & $0.7 \pm 0.5$ & $0.10 \pm 0.04$ \\
\hline Zeta-carotene & $\mathrm{C}_{40} \mathrm{H}_{60}$ & $\begin{array}{c}\text { corn } \\
\text { yellow tomatoes }\end{array}$ & No data & No data & $0.12-0.14[30]$ \\
\hline Lutein & $\mathrm{C}_{40} \mathrm{H}_{56} \mathrm{O}_{2}$ & $\begin{array}{c}\text { leafy vegetables (spinach) } \\
\text { eggs } \\
\text { broccoli }\end{array}$ & $\begin{array}{c}12,198 \pm 1930 *[29] \\
835 *[29]^{\$} \\
1403 \pm 40 *[29]\end{array}$ & $2.2 \pm 0.8^{*}$ & $0.33 \pm 0.10 *$ \\
\hline Zeaxanthin & $\mathrm{C}_{40} \mathrm{H}_{56} \mathrm{O}_{2}$ & $\begin{array}{c}\text { corn } \\
\text { eggs } \\
\text { leafy vegetables (spinach) }\end{array}$ & $\begin{array}{c}1355 *[29] \\
51 \pm 6[31] \\
445 \pm 21[31]\end{array}$ & see lutein & see lutein \\
\hline Beta-cryptoxanthin & $\mathrm{C}_{40} \mathrm{H}_{56} \mathrm{O}$ & $\begin{array}{l}\text { citrus fruits (oranges) } \\
\text { loquat } \\
\text { papaya }\end{array}$ & $\begin{array}{c}1275 \pm 73[31] \\
\text { Ca. } 25-510[32] \\
589 \pm 160[29]\end{array}$ & $0.3 \pm 0.4$ & $0.23 \pm 0.09$ \\
\hline Violaxanthin & $\mathrm{C}_{40} \mathrm{H}_{56} \mathrm{O}_{4}$ & $\begin{array}{l}\text { leafy vegetables (spinach) } \\
\text { bell peppers }\end{array}$ & $\begin{array}{c}2765 \pm 242[31] \\
457 \pm 9[31] \\
\end{array}$ & $1.2[31]$ & not detectable \\
\hline Neoxanthin & $\mathrm{C}_{40} \mathrm{H}_{56} \mathrm{O}_{4}$ & $\begin{array}{l}\text { leafy vegetables (spinach) } \\
\text { bell peppers }\end{array}$ & $\begin{array}{l}445 \pm 21[31] \\
361 \pm 19[31]\end{array}$ & $0.5[31]$ & not detectable \\
\hline Astaxanthin & $\mathrm{C}_{40} \mathrm{H}_{52} \mathrm{O}_{4}$ & $\begin{array}{c}\text { Salmon } \\
\text { green algae (Haematococcus pluvialis) }\end{array}$ & $\begin{array}{c}2.6-3.8 \%{ }^{\$}[33] \\
3 \%{ }^{\$}[33]\end{array}$ & No general data & $\begin{array}{c}\text { Normally not detectable, but } 0.2 \\
\text { after suppl. with } 6 \text { mg every } \\
\text { other } \mathrm{d} \text { for } 10 \mathrm{~d}[34]\end{array}$ \\
\hline Fucoxanthin & $\mathrm{C}_{42} \mathrm{H}_{58} \mathrm{O}_{6}$ & brown algae & 200-2000 [35] & No general data & not detectable \\
\hline Cantaxanthin & $\mathrm{C}_{40} \mathrm{H}_{52} \mathrm{O}_{2}$ & $\begin{array}{c}\text { crabs } \\
\text { salmon } \\
\text { Strassburger sausages }\end{array}$ & $\begin{array}{c}\text { No data } \\
120[36] \\
1500[37]\end{array}$ & $6.1 \mu \mathrm{g} / \mathrm{kg}[38](\sim 0.4 \mathrm{mg} / \mathrm{d})$ & no data \\
\hline
\end{tabular}


Table 1. Cont.

\begin{tabular}{|c|c|c|c|c|c|}
\hline Name & Chemical Formula & Found in & $\begin{array}{l}\text { Typical Conc. in Food } \\
(\mu \mathrm{g} / \mathbf{1 0 0} \mathrm{g})\end{array}$ & Dietary Intake ${ }^{£}(\mathrm{mg} / \mathrm{d})$ & Conc. in Plasma/Serum ${ }^{£}(\mu \mathrm{M})$ \\
\hline Lycopene & $\mathrm{C}_{50} \mathrm{H}_{56}$ & $\begin{array}{c}\text { tomatoes } \\
\text { tomato products (ketchup) } \\
\text { watermelon } \\
\text { pink grapefruit }\end{array}$ & $\begin{array}{c}2573 \pm 54[29] \\
12062 \pm 445[29] \\
4532 \pm 386[29] \\
1419 \pm 525[29]\end{array}$ & $4.6 \pm 2.4$ & $0.59 \pm 0.27$ \\
\hline Phytoene & $\mathrm{C}_{40} \mathrm{H}_{64}$ & $\begin{array}{c}\text { tomatoes } \\
\text { tomato products (ketchup) } \\
\text { watermelon } \\
\text { pink grapefruit }\end{array}$ & $\begin{array}{c}1388 \pm 156[31] \\
3494 \pm 279[31] \\
1172 \pm 77[31] \\
617 \pm 60[31]\end{array}$ & $2.0[31]$ & $0.10-0.11[30]$ \\
\hline Phytofluene & $\mathrm{C}_{40} \mathrm{H}_{62}$ & $\begin{array}{c}\text { tomatoes, } \\
\text { tomato products (ketchup) } \\
\text { watermelon } \\
\text { pink grapefruit }\end{array}$ & $\begin{array}{c}401 \pm 54[31] \\
1034 \pm 97[31] \\
443 \pm 26[31] \\
208 \pm 34[31]\end{array}$ & $0.7[31]$ & $0.27-0.30[30]$ \\
\hline
\end{tabular}

means \pm SD. 


\section{Markers of Oxidative Stress Relevant for Carotenoids}

\subsection{Introduction}

Due to their elongated structure and the delocalized $\pi$-electron system, combined with the high hydrophobicity of carotenoids (log-p-values about 8-11, [39]), carotenoids may act as antioxidants, quenching especially lipid peroxides, plus further consuming oxygen in this process, following the reactions proposed earlier [40], resulting in a resonance stabilized molecule:

$$
\begin{gathered}
\mathrm{R} \bullet+\mathrm{Car} \rightarrow \mathrm{R}-\mathrm{Car} \bullet \\
\mathrm{RCar} \bullet+\mathrm{O}_{2} \rightarrow \mathrm{RCarO}_{2} \bullet
\end{gathered}
$$

In this regard, carotenoids have originally been appraised due to their reaction with free lipid radicals in the cell membrane, protecting the membrane from further oxidative damage [41]. The theory behind the influence of carotenoids on markers of oxidative stress and associated markers is that carotenoids, which are situated especially within the lipid bilayer of cell membranes (Figure 1), with the xanthophylls' polar head on the outside and the apolar end in the inner part of the membrane, and the carotenes rather in the inside of the membrane, inhibit the oxidation of lipids, reducing lipid peroxidation, and thus reducing the formation of MDA, F2-isprostane and other markers of lipid peroxidation, such as acrolein and 4-hydroxynonenal (4-HNE). Their quenching of singlet oxygen may also reduce the formation of lipid peroxides [42]. Carotenoids likely form a resonance stabilized carbon-centred radical [40], and can react via both electron transfer and hydrogen abstraction [43]. Direct reaction with the hydroxyl-radical $(\mathrm{OH} \cdot)$ is less likely, as this radical is likely rather found in the aqueous layer, with a concentration in a lipid phase such as oleic acid being 1000 times lower than in the aqueous phase [44], though its presence has been reported, at least in vitro [45].

In addition, carotenoids appear to have different properties when it comes to quenching of lipid peroxidation, depending on the mechanism of lipid peroxide formation. In a study on isolated erythrocytes, tBHP (tert-butyl-hydroperoxide)-induced lipid peroxidation was most efficiently prevented by lycopene, though when peroxyl radicals were generated by AAPH (2,2'-Azobis(-amidinopropane) dihydrochloride) lutein was more efficient, while lycopene had no effect [46]. When testing GSH (reduced glutathione) depletion by peroxyl radicals, carotenoids were completely ineffective, likely again due to the low interaction with the aqueous phase. However, in this study, carotenoids were added in suspended PBS buffer, which is different from the physiologic situation, where carotenoids are present within the cell membrane or transported in lipoproteins.

\subsection{Markers Related to Lipid Peroxidation and Free Radicals}

Due to their potential value for early diagnostics, markers of lipid oxidation have been frequently investigated in human studies [47]. The most often studied marker is MDA, a product originating from the peroxidation of polyunsaturated fatty acids, both from omega- 6 fatty acids such as arachidonic acid and omega-3 fatty acids such as linolenic acid [48], involving cyclo-oxygenase 2 (COX-2) as a first step [49]. It is also toxicologically relevant, as MDA can form adducts with nucleosides [48]. Similar markers include 4-HNE and acrolein [50]. 4-Hydroxynonenal is a very reactive aldehyde, reacting with thiols and amino-groups, being considered as a "second toxic messenger of free radicals" [48], thus plausibly being mechanistically linked to oxidative stress status. On the other hand, samples must be stored at least at $-80{ }^{\circ} \mathrm{C}$, and then for only a few months, as losses of $20 \%$ during 22 months following plasma storage were found [51]. Measurements of MDA can be conducted both in urine and in plasma; however, this marker has been criticized to not always show a clear relation to oxidative stress, and may be influenced by dietary formed MDA [52]. It is also not very stable during storage; when stored at $-20^{\circ} \mathrm{C}$, samples should be analysed within 3 weeks, while 10 fold higher values were found after 1 year of storage, due to the continued oxidation and formation ex vivo [53]. 


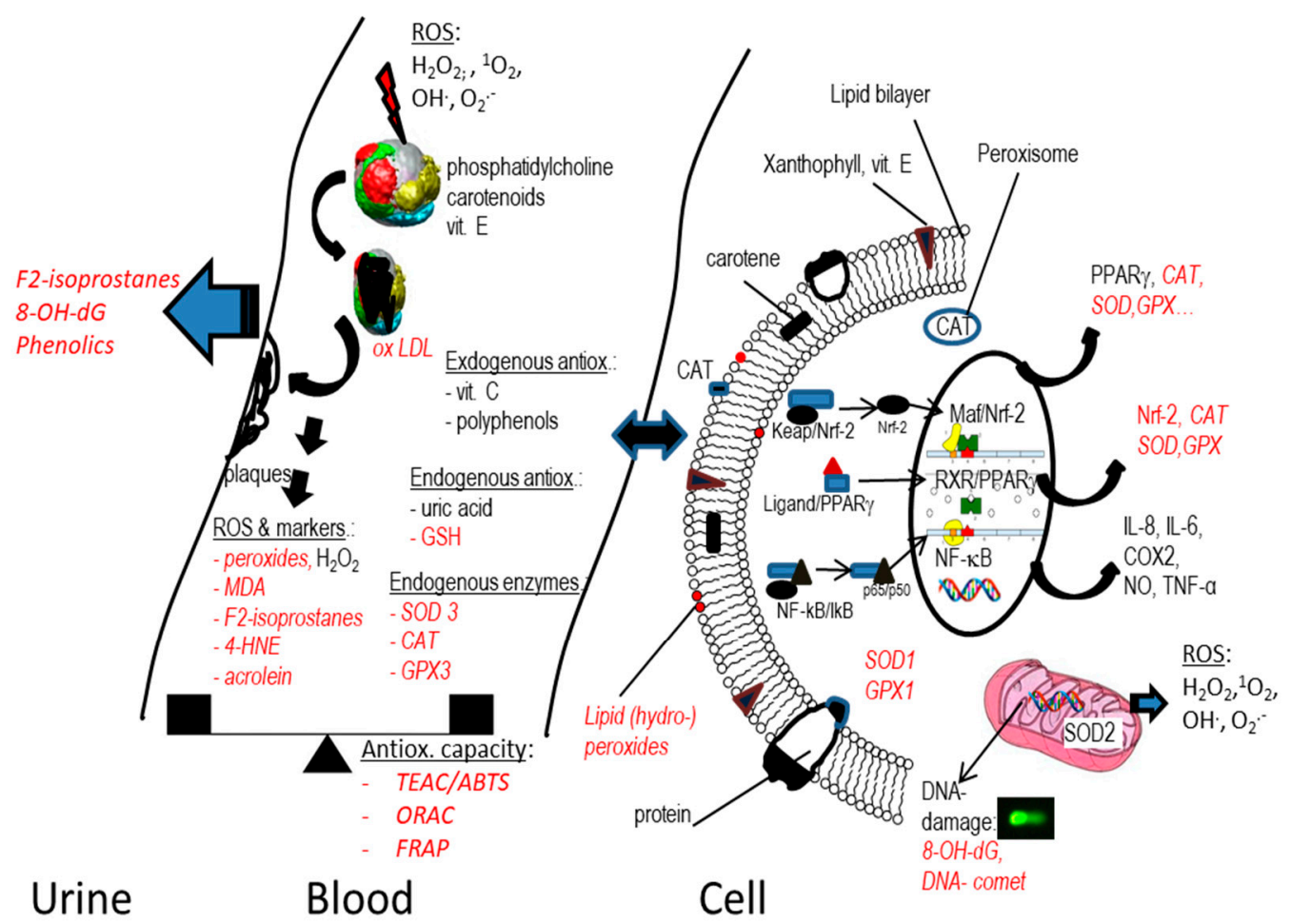

Figure 1. Overview of oxidative stress and employed markers related to carotenoid observational studies and intervention trials. Italic and red-printed items constitute frequently measured markers of oxidative stress and antioxidant capacity. For abbreviations, see the footnotes in Table 2.

A product also related to the oxidation of arachidonic acid, similar to MDA, though the result of a non-enzymatic peroxidation of prostaglandins originating from arachidonic acid, is 8-isoprostaglandin F2 $\alpha$ (8-isoPGF2 $\alpha$ ), which has been found to be closely related to MDA concentrations in plasma [54]. However, it is present at much lower concentrations. Its free form is produced after cleavage of the ester and then circulates in the plasma. However, other isoprostanes have also been measured as markers of oxidative stress, containing a total of 64 isomers [55] and are denoted here for simplicity as F2-isoprostanes. 8-isoPGF2 $\alpha$ is comparatively stable in vivo, and can also be assessed via the urine, a less complex matrix. It has been advocated as a biomarker of oxidative stress in chronic diseases such as diabetes type 2 [56]. However, as for MDA, it is prone to further oxidation upon storage, especially at prolonged times and temperatures and repeated thawing and freezing. For example, though a 6 month stability at $-80^{\circ} \mathrm{C}$ has been reported, concentrations increased 1.4 fold after three cycles of thawing and freezing [57], and higher temperatures may result in multiple increases [57].

In addition to the reaction with free radicals, carotenoids may also directly quench singlet oxygen $\left({ }^{1} \mathrm{O}_{2}\right)$ [42]. This reaction would first result in a triplet state of carotenoids, following the dissipation of excess energy in the form of rotational and vibrational activity, and thus heat:

$$
\begin{gathered}
{ }^{1} \mathrm{O}_{2}+\mathrm{CAR} \rightarrow{ }^{3} \mathrm{O}_{2}+{ }^{3} \mathrm{CAR} \\
{ }^{3} \mathrm{CAR} \rightarrow \mathrm{CAR}+\text { heat }
\end{gathered}
$$

This reaction may take place during an "oxidative burst" of immune cells such as macrophages, neutrophils or monocytes, in which large amounts of ROS are produced, e.g., during phagocytosis [58,59]. Singlet oxygen may react preferably with double-bonded molecules such as nucleic acids and poly-unsaturated fatty acids (PUFAs), by energy transfer or chemical reactions [60]. However, singlet oxygen may also react with other antioxidants such as vitamin $\mathrm{E}$, and a protective role of carotenoids on singlet oxygen-induced vitamin $\mathrm{E}$ losses has been shown [61]. This reaction may especially take place in oxygen-rich environments such as the mitochondria [62]. A common marker 
of nucleic acid degradation has, therefore, been frequently employed as a marker of such reactions, namely 8-hydroxy-2'-deoxy-guanosine (8-OH-dG). This marker originates following the reaction of a hydroxyl-radical $(\mathrm{OH} \cdot)$ with the guanine nucleobase of mitochondrial or nuclear DNA [63]. This radical is formed, for example, from ${ }^{1} \mathrm{O}_{2}$ reacting to the superoxide radical, then hydrogen peroxide, then the hydroxyl radical, and thus, $8-\mathrm{OH}-\mathrm{dG}$ is especially a marker for the latter [64]. Compared to MDA and isoprostanes, it is relatively stable once separated from nucleotide-containing material and can be measured both in plasma and in urine. For instance, $8-\mathrm{OH}-\mathrm{dG}$ in urine was stable for 6 years stored at $-20{ }^{\circ} \mathrm{C}[65]$.

In addition to these small chemical molecules, various oxidative stress assessments have focussed on lipoproteins, being themselves prone to oxidation. A very frequently employed marker is the stability of low-density lipoprotein (LDL) particles isolated from blood plasma, and monitoring its stability following exposure to a pro-oxidant such as copper. This may constitute a meaningful marker for carotenoids, as LDL particles contain carotenoids, and the majority of carotenes (76\%) appears to be bound to LDL [66], as opposed to xanthophylls, which were about equally distributed between high density lipoprotein (HDL) and LDL [67]. Of note, oxidized LDL particles in vivo are precursors for endothelial damage and the formation of atherosclerotic plaques [68], and thus, atherosclerosis [69]. The lipid peroxides formed within lipoproteins can be measured by employing antibodies, such as against oxidized phosphatidylcholines, oxidized phospholipids, or oxidized lysine residues of the apoprotein APO-B-100 [70].

Finally, though more analytically challenging, lipid peroxides can also be measured directly. In general, their limited stability and high reactivity impedes measuring such compounds, and sophisticated methods including GC and LC, coupled to MS, are required [71]. EFSA nevertheless accepts direct measurements of lipid peroxides as a valid marker of oxidative stress [72] and recommends the measurement of phosphatidylcholine hydroperoxides in blood or tissues by chemoluminescence-based LC [73].

\subsection{Markers Related to Antioxidant Capacity/Status}

Additional markers have focussed on the related antioxidant status/capacity status, rather than oxidative stress. These include markers assessing the total quenching capacity of a plasma aliquot, following, for example, exposure to a radical forming agent. These may focus either on singlet oxygen quenching, metal chelators (as metals which can be reduced, such as iron, act as agents enhancing oxidation), electron donators and hydrogen donors [74]. Though a large number of such tests exists [75], only a few are commonly used. In this respect, oxygen radical absorbance capacity (ORAC, [76]), ferric reducing antioxidant power assay (FRAP, [77]), and Trolox equivalent antioxidant capacity (TEAC/ABTS, [78]), together with the DPPH (1,1-diphenyl-2-picrylhydrazyl) assay [79] have most frequently been employed (Table 2). However, these assays typically rely on aqueous or alcoholic extracts of the plasma and may fail to fully take into account lipophilic antioxidants, including carotenoids. A few attempts have also been incorporating lipophilic extracts, such as those based on hexane extracts followed by ORAC in acetone-based media [80] or ABTS in ethanolic media [81]. Due to their dependency on exogenous radical producers, their physiological relevance has been questioned $[74,82]$.

Other markers are related to more indirect cellular mechanisms of oxidative stress, in close relation to inflammation, involving cellular signalling cascades and transcription factors (TFs). The two most commonly examined TFs in this respect include Nrf-2 and NF- $\mathrm{KB}$, related to antioxidant enzymes and inflammatory agents, respectively. The activation of these two TFs is outside the scope of this review; thus, the reader is referred to comprehensive reading elsewhere $[18,83,84]$.

Activation of Nrf-2 by, for example, electrophilic compounds, will activate the body's' own antioxidant defence mechanisms, especially including enzymes such as CAT, GPx (glutathione peroxidase), and SOD (Table 2). Though most of these enzymes are rather active intracellularly, extracellular isoforms exist (e.g., GPx3, SOD3, membrane bound catalase), and in general, good 
correlations between intracellular levels and blood plasma have been reported [85]. However, typically, catalase is present in the peroxisomes, while GPx can be found in the cytoplasm, especially of erythrocytes (GPx1) and extracellular (as GPx3), and SOD in the cytoplasm (SOD1), mitochondria (SOD2) and extracellular space (SOD3). While SOD is more specifically targeting the reaction of the superoxide anion radical $\left(\mathrm{O}_{2}{ }^{-}\right)$to form hydrogen peroxide $\left(\mathrm{H}_{2} \mathrm{O}_{2}\right)$, CAT and GPx react with the latter to form water [86]. However, all three enzymes are involved in the removal of the very reactive superoxide anion, especially originating from cellular respiration in the mitochondria, but also from other mechanisms such as xanthine oxidase (involved in the production of uric acid), which then could trigger protein and lipid oxidation, among others [87].

\subsection{Markers Related to Nuclear Factors and Inflammation}

Nuclear receptors are ligand-activated, TF-sensing, hormone-like lipophilic molecules which can cross the plasma membrane into the cell, regulating gene expression, and thus regulating many cellular processes related to cellular growth and metabolism, immune system, etc., and can be classified according to their ligands [88]. Thus, they act as TFs, though they may also regulate functions within the cytoplasm.

Regarding carotenoids and their metabolites, RAR/RXR [89] and PPAR/RXR dimers [90] have been associated with carotenoid and vitamin A status. While RAR/RXR targets many genes related to cell growth, differentiation, survival, the immune system and apoptosis [91], PPAR/RXR has been associated with cellular differentiation, lipid metabolism and insulin sensitivity [92]. Thus, apo-carotenoids, mostly those related to vitamin A active compounds [89] but not only [93], have been associated with these nuclear factors. As the metabolism of adipocytes may especially be a main driver of the metabolic syndrome associated with oxidative stress [94], such endpoints may be interesting and rather novel markers of (apo-)carotenoid bioactivity.

Contrarily to Nrf-2, interaction of NF- $\kappa B$ with electrophilic compounds would prevent its activation and translocation into the nucleus, reducing the expression of pro-inflammatory agents such as a variety of cytokines such as chemokines (chemotactic cytokines), including TNF- $\alpha$, IL-1, IL-8, and IF- $\gamma$. While cytokines are generally signalling molecules, the chemokines are small cytokines especially attracting leucocytes to the site of infection/inflammation $[95,96]$. As some carotenoids, especially the carotenes, are not very electrophilic, it has been argued that rather their apolar metabolites, i.e., apo-carotenoids, such as retinoic acid, are the more bioactive agents in this respect [16,17]. As xanthophylls may show higher electrophilicity, these may also be hypothesized as being more bioactive regarding the interaction with these TFs. 
Table 2. Selected markers of oxidative stress as well as commonly employed markers of inflammation in human studies assessing mid- to long-term effects of carotenoids.

\begin{tabular}{|c|c|c|c|c|c|}
\hline Marker & Matrix & Marker of & Disadvantage & Advantages & Ref. \\
\hline \multicolumn{6}{|c|}{ Lipid Peroxidation Related } \\
\hline Lipid peroxides $(\mathrm{LOOH})$ & Plasma & $\begin{array}{l}\text { Oxidative stress, measured, e.g., } \\
\text { as phosphatidylcholine } \\
\text { hydroperoxides by } \\
\text { chemiluminescence-based LC, } \\
\text { other fluorescence probes, or } \\
\text { linoleates by GC-MS }\end{array}$ & $\begin{array}{l}\text { Presumably unstable in matrix, to } \\
\text { be measured in fresh samples, } \\
\text { though not much data at present, } \\
\text { analytically challenging }\end{array}$ & Accepted by EFSA [72] & [97] \\
\hline Malon-dialdehyde (MDA) & Urine, plasma * & $\begin{array}{c}\text { Enzymatic (COX-2) and } \\
\text { non-enzymatic lipid peroxidation } \\
\text { of PUFAs }\end{array}$ & $\begin{array}{l}\text { Limited stability during storage, a } \\
\text { few weeks at }-20^{\circ} \mathrm{C}\end{array}$ & $\begin{array}{l}\text { Relatively high concentration, } \\
0.1-3 \mu \mathrm{M}\end{array}$ & [48] \\
\hline F2-isoprostanes & Urine, plasma & $\begin{array}{l}\text { Non-enzymatic lipid } \\
\text { peroxidation of PUFAs }\end{array}$ & $\begin{array}{l}\text { Limited storage stability, esp. } \\
\text { thaw/freeze cycles, } 6 \text { months at }-80 \\
{ }^{\circ} \mathrm{C} \text { [57], further formation ex vivo, } \\
\text { low concentration }\end{array}$ & $\begin{array}{l}\text { Accepted marker for oxidative } \\
\text { stress, accepted by EFSA }\end{array}$ & [56] \\
\hline 4-hydroxy-nonenal (4-HNE) & Urine, plasma & $\begin{array}{c}\text { Enzymatic (COX-2) and } \\
\text { non-enzymatic lipid peroxidation } \\
\text { of omega-6 fatty acids }\end{array}$ & $\begin{array}{l}\text { Limited storage stability }(20 \% \text { losses } \\
\text { at }-80^{\circ} \mathrm{C} \text { over } 22 \text { months [51], low } \\
\text { conc. }(70-110 \mathrm{nM}) \text {, reactive in vivo }\end{array}$ & $\begin{array}{l}\text { Reactive compound plausibly } \\
\text { related to further oxidative } \\
\text { stress in vivo }\end{array}$ & [98] \\
\hline Acrolein & Urine, plasma & Lipid peroxidation & $\begin{array}{l}\text { Limited stability, most reactive of } \\
\text { the lipid peroxide markers }\end{array}$ & $\begin{array}{l}\text { Toxic and relevant product of } \\
\text { lipid peroxidation }\end{array}$ & [99] \\
\hline Protein carbonyls & Plasma & Oxidation of proteins & Several measurement techniques & $\begin{array}{l}\text { Related to several diseases, } \\
\text { relatively stable products, } \\
\text { several months at }-80^{\circ} \mathrm{C}[100]\end{array}$ & {$[101,102]$} \\
\hline $\begin{array}{l}\text { 8-hydroxy-deoxyguanosine } \\
\text { (8-OH-dG) }\end{array}$ & Urine, plasma & $\begin{array}{l}\text { Oxidation of DNA (reactive } \mathrm{N} \\
\text { and } \mathrm{O} \text { species), especially }{ }^{1} \mathrm{O}_{2} \\
\text { also marker of cancerogenic risk }\end{array}$ & $\begin{array}{c}\text { Enzymatic kits with cross-reactivity } \\
\text { to various DNA/RNA breakdown } \\
\text { products }\end{array}$ & $\begin{array}{l}\text { Quite stable ex vivo, } 6 \text { y at }-20 \\
{ }^{\circ} \mathrm{C} \text { for urine [65], same for } \\
\text { plasma ( } 2 \text { y) for }-80^{\circ} \mathrm{C}[103]\end{array}$ & [63] \\
\hline Oxidized LDL (ox-LDL) & plasma & $\begin{array}{l}\text { Marker of oxidative stress, } \\
\text { atherosclerosis }\end{array}$ & $\begin{array}{l}\text { Various methods, e.g., AB against } \\
\text { oxidized phosphatidylcholine, } \\
\text { different units, low ng/mg range, } \\
\text { stability may be limited to some } \\
\text { months at }-80^{\circ} \mathrm{C} \text {, but lack of data }\end{array}$ & $\begin{array}{c}\text { Accepted marker for } \\
\text { atherosclerosis, accepted } \\
\text { by EFSA }\end{array}$ & [69] \\
\hline $\begin{array}{l}\text { Copper-induced oxidation of } \\
\text { LDL particles }\end{array}$ & Plasma & $\begin{array}{l}\text { Lipid peroxides present in LDL } \\
\text { particles versus present } \\
\text { antioxidant (e.g., vitamin E), } \\
\text { marker of atherosclerosis risk }\end{array}$ & $\begin{array}{l}\text { Ox. kinetics and formation of } \\
\text { conjugated dienes depend on } \mathrm{Cu} \\
\text { conc. employed, questionable } \\
\text { physiol. relevance }\end{array}$ & $\begin{array}{l}\text { Possible relevant marker of } \\
\text { carotenoid presence in } \\
\text { lipoproteins }\end{array}$ & {$[104,105]$} \\
\hline
\end{tabular}


Table 2. Cont

\begin{tabular}{|c|c|c|c|c|c|}
\hline Marker & Matrix & Marker of & Disadvantage & Advantages & Ref. \\
\hline \multicolumn{6}{|c|}{ Antioxidant Capacity } \\
\hline $\begin{array}{l}\text { Ferric-reducing antioxidant } \\
\text { power assay (FRAP) }\end{array}$ & Plasma & $\begin{array}{l}\text { Antioxidant capacity, based on } \\
\text { electron transfer }\end{array}$ & Limited to aqueous systems & Ease of use & [77] \\
\hline $\begin{array}{l}\text { Oxygen radical absorbance } \\
\text { capacity (ORAC) }\end{array}$ & Plasma & $\begin{array}{c}\text { Antioxidant capacity, hydrogen } \\
\text { transfer }\end{array}$ & $\begin{array}{l}\text { Limited to peroxyl radicals, } \\
\text { temperature dependence }\end{array}$ & $\begin{array}{l}\text { Integral over time is measured, } \\
\text { less susceptible to altered } \\
\text { kinetics }\end{array}$ & [76] \\
\hline ABTS & Plasma & $\begin{array}{l}\text { Antioxidant capacity, based on } \\
\text { hydrogen and electron transfer }\end{array}$ & $\begin{array}{l}\text { Several antioxidants may not react } \\
\text { with ABTS }\end{array}$ & Ease of use, stability of ABTS & [78] \\
\hline DPPH & Plasma & $\begin{array}{l}\text { Antioxidant capacity, based on } \\
\text { hydrogen and electron transfer }\end{array}$ & $\begin{array}{l}\text { Several antioxidants may not react } \\
\text { with DPPH }\end{array}$ & Ease of use, stability of DPPH & {$[79,106]$} \\
\hline \multicolumn{6}{|c|}{ Antioxidant Enzymes and Endogenous Antioxidant } \\
\hline Superoxide dismutase (SOD) & Plasma, tissues & $\begin{array}{c}\text { Responsible for removal of } \mathrm{OH}^{-} \text {. } \\
\text { via } \mathrm{H}_{2} \mathrm{O}_{2} \text { dismutation, defence } \\
\text { against ROS, low conc. associated } \\
\text { with disbalanced ROS }\end{array}$ & $\begin{array}{l}\text { Not always clear dose-response } \\
\text { relationship }\end{array}$ & $\begin{array}{l}\text { Low levels linked to several } \\
\text { chronic diseases }\end{array}$ & {$[86,107]$} \\
\hline Glutathione peroxidase (GPx) & Plasma, tissues & $\begin{array}{l}\text { Removal of peroxides especially } \\
\text { in cytosol }\end{array}$ & Also related to ageing & $\begin{array}{c}\text { Reduced conc. related to } \\
\text { various diseases and increased } \\
\text { ROS }\end{array}$ & {$[108,109]$} \\
\hline Reduced glutathione (GSH) & Tissues, plasma & $\begin{array}{c}\text { Most abundant cytosolic } \\
\text { non-protein thiol, ROS scavenger }\end{array}$ & $\begin{array}{l}\text { Limited predictability alone, } \mathrm{pH} \\
\text { dependence }\end{array}$ & $\begin{array}{l}\text { Relatively high concentrations } \\
\text { (mM) }\end{array}$ & [108] \\
\hline Catalase (CAT) & Tissues, blood cells & $\begin{array}{c}\mathrm{H}_{2} \mathrm{O}_{2} \text { disproportionation, marker } \\
\text { of } \mathrm{ROS} \text {, removal of peroxinitrate } \\
\text { and NO, low conc. associated } \\
\text { with disbalanced ROS }\end{array}$ & $\begin{array}{l}\text { Limited susceptibility to dietary } \\
\text { interventions }\end{array}$ & $\begin{array}{l}\text { Low levels linked to several } \\
\text { chronic diseases }\end{array}$ & [110-112] \\
\hline \multicolumn{6}{|c|}{ Inflammation: Pro-Inflammatory Cytokines including Chemokines and Acute Phase Proteins } \\
\hline TNF- $\alpha$ & Plasma & $\begin{array}{l}\text { Activation of immune cells, } \\
\text { related to fever, apoptosis }\end{array}$ & $\begin{array}{l}\text { Unclear cut-offs for health } \\
\text { determinant }\end{array}$ & $\begin{array}{l}\text { Stable for at least } 3 \mathrm{y}\left(-80^{\circ} \mathrm{C}\right) \\
\text { [113], established marker of } \\
\text { chronic disease }\end{array}$ & [114] \\
\hline IF- $\gamma$ & Plasma & $\begin{array}{l}\text { Produced by killer cells, part of } \\
\text { innate immune response, } \\
\text { macrophage activation }\end{array}$ & $\begin{array}{c}\text { Rather related to immune system } \\
\text { activation }\end{array}$ & $\begin{array}{l}\text { Related to autoimmune } \\
\text { diseases, stable for } 2 \mathrm{y} \text { at } \\
-80^{\circ} \mathrm{C}[113]\end{array}$ & [115] \\
\hline IL-1 & Plasma & $\begin{array}{l}\text { Related to fever, bone marrow } \\
\text { cell differentiation }\end{array}$ & $\begin{array}{l}\text { Many molecular aspects of } \\
\text { activation not understood }\end{array}$ & $\begin{array}{l}\text { Stable for at least } 2 \mathrm{y} \\
\quad\left(-80^{\circ} \mathrm{C}\right)[113]\end{array}$ & [116] \\
\hline
\end{tabular}


Table 2. Cont.

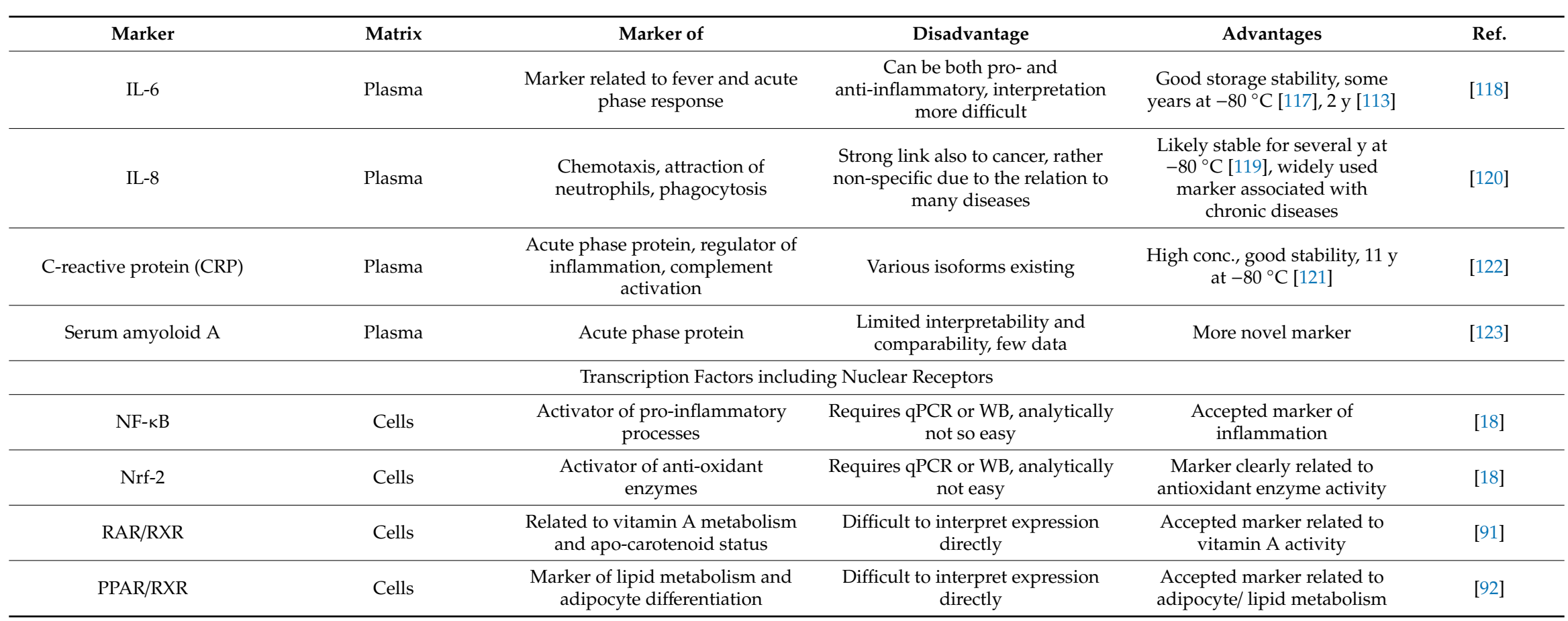

* or serum; AB: antibody; ABTS: 2,2'-Azino-bis(3-ethylbenzothiazoline-6-sulfonic acid) diammonium salt; conc.: concentration; COX-2: cyclooxygenase; DPPH: 2,2-Diphenyl-1-picrylhydrazyl; EFSA: European Food Safety Authority; GC: Gas-chromatography; IF: interferon; IL: interleukin; LDL-C: low density lipoprotein; LC: liquid chromatography; NF-kB: nuclear factor kappa B; NO: nitric oxide; Nrf-2: nuclear factor erythroid 2-related factor 2; ox.: oxidatition/oxidative; PPAR: peroxisome proliferator-activated receptor; PUFAs: polyunsaturated fatty acids; RAR: retinoic acid receptor; ROS: reactive oxygen species; RXR: retinoid X receptor; TNF- $\alpha$ : tumour necrosis factor alpha. WB: Western blot. 
For this purpose, a number of downstream targets of these TFs have been assessed in human trials (Table 2). In general, the downstream cytokines are responsible for stirring the response of the host to infection and trauma and to regulate immune responses, including inflammation. Thus, a certain reaction is desired by the human host, but a prolonged activation may aggravate chronic diseases, adding to chronic inflammation, tissue damage, fever and increased risk of cancer. Contrarily, other cytokines such as IL-4, IL-10, IL-13 and transforming growth factor beta (TGF- $\beta$ ) are rather anti-inflammatory [124]. IL-1, TNF- $\alpha$ and interferon gamma (IFN- $\gamma$ ) are secreted by B-cell lymphocytes to stimulate macrophage recruitment [124], while IL-8, secreted by several cells including macrophages, especially enhances leukocyte infiltration [125]. IL-6 may have both pro- and anti-inflammatory properties [126] and is also secreted by B-cells, enhancing, for example, T-cell activity and has various effects such as enhancing synthesis of acute phase proteins such as $\mathrm{C}$-reactive protein (CRP) and serum amyloid A, among others. Stability of storage at $-80^{\circ} \mathrm{C}$ is somewhat limited and analysis should be carried out in general within 2 years [113].

\subsection{Conclusions}

At the very least, it should be emphasized that no single assay is likely to truly reflect reactive oxygen species status and antioxidant activity due to the various biological aspects, compartments, and type of samples/extracts involved. Complimentary tests such as employing living cells and detecting bioactive compounds by, for example, chromatographic methods have, thus, been much encouraged [74]. The EFSA has claimed that, regarding such antioxidant tests, only F2-isoprostanes or also direct measurement of lipid peroxides and a marker of LDL stability such as oxLDL are acceptably established, and thus, preferred markers. Though the EFSA also acknowledges other tests, such as 8-OH-dG and protein carbonyls as auxiliary markers [72], by themselves, many of these markers, including MDA and ex-vivo stability measurements of LDL, are not acknowledged as being reliable on their own. Likewise, antioxidant tests, including ORAC, FRAP, TEAC, have, according to the EFSA, not clearly been shown to be of physiological relevance.

\section{Results from Human Observational Studies}

Observational studies, no matter whether cross-sectional, case-control, or longitudinal, cannot establish causality. However, they can contribute to the body of evidence, especially in large-scale studies when confounding factors have been taken into account. Regarding carotenoids, dietary intake both with and without dietary supplements have been conducted and the relation of carotenoid intake/plasma concentrations and markers of diseases related to oxidative stress, and more specifically, related to their antioxidant activity and radical quenching ability, have been conducted (Table 3). In general, mostly negative associations between circulating carotenoids in plasma and markers of oxidative stress have been reported, especially in studies with non-healthy subjects, often having higher markers of oxidative stress than healthy subjects, where the narrower distribution impedes the findings of significant correlations to markers of oxidative stress. However, it cannot be excluded that underreporting of null or negative results distort this picture, as positive findings are likely to result in more attention.

\subsection{Studies with Non-Healthy Subjects}

As several cardiometabolic complications are known to be affiliated with oxidative stress, several studies have focussed on this disease. In a study with subjects at risk for atherosclerosis versus controls, a higher concentration of both MDA and 8,12-isoprostane F2a-VI were related to decreased concentrations of individual carotenoids, despite fruit and vegetable intake being comparable [127], highlighting that perhaps such subjects indeed require higher dietary intake to maintain comparable plasma concentrations. However, often dietary intake of fruits and vegetables is not accounted for, and thus it is unclear whether a higher turnover of antioxidants is truly the cause for the observed negative associations between elevated markers of oxidative stress and reduced circulating carotenoids. 
In a small-scale study with type 1 diabetic subjects versus healthy controls, the diabetic group had much higher lipid peroxides (lipid normalized) and MDA compared to healthy controls, while the plasma beta-carotene concentration was much lower $(<50 \%)$. Both GSH and GPx were also lower, while SOD was higher [128], though no direct correlations were established. This study emphasized the relation of hyperglycaemia causing oxidative stress and increased requirements of antioxidants. In another small-scale study with subjects being partially insulin resistant, inverse associations of hydroperoxides with several carotenoids were found in otherwise healthy subjects, including alpha-carotene, beta-cryptoxanthin, zeaxanthin, but not beta-carotene, lutein and lycopene [129]. In many metabolic conditions, obesity is an independent risk-factor and may increase oxidative stress. In a study with morbidly obese subjects, undergoing vertical banded gastroplasty [130], it was shown that plasma MDA decreased by around 50\% post-surgery, though carotenoid-levels did not change; however, alpha-tocopherol significantly increased. As dietary intake was not determined, it is difficult to judge these results, but it was thus shown that ameliorating obesity tends to improve antioxidant and ROS status, also suggesting that they are intertwined.

In more severe cardiometabolic complications such as with myocardial infarction, a cross-sectional study with such subjects in cardiogenic shock, patients versus healthy controls showed higher MDA, conjugated dienes and reduced activities/concentrations of erythrocyte antioxidant enzymes, including SOD, CAT, GPx, erythrocyte and plasma GSH, as well as beta-carotene. However, direct correlation analyses were not carried out [131]. In a study with patients with congestive heart failure, F2-isoprostanes were higher in class III than in class II NYHA (Ney York Heart Association scale) patients, and inverse correlations between F2-isoprostanes and plasma levels of lutein, lycopene, zeaxanthin and alpha- and beta-carotene were found, which were also correlated with SOD [132]. Finally, in a study with over 100 subjects with various stages of acute coronary syndromes, the severity of symptoms was associated with increased MDA and protein carbonyls, as well as decreased total plasma carotenoids, which were significantly correlated with both markers of ROS [133]. Similar as for markers related to oxidative stress, a study with 68 acute ischemic stroke patients found lower plasma lycopene and alpha- and beta-carotene concentrations compared to normal controls, and these were significantly inversely correlated to CRP [134] (Table 3).

Several studies have focussed on cancer as another common disease where oxidative stress and inflammation do play a role. In a study with approximately 70 subjects at high risk for developing liver cancer, urinary F2-isoprostanes and plasma beta-carotene levels were measured and found to be inversely correlated [135]. Both carotenoids and reduced glutathione (GSH) were stated to be the best predictors or lipid peroxidation. Similarly, reduced urinary 15 -isoprostane $\mathrm{F}_{2 \mathrm{t}}$ concentrations, but higher circulating total carotenoids, were associated in a case-control study with lower risk of lung cancer [136]. However, no direct correlations were reported in this study. In a small-scale case-control study with lung cancer cell subjects, 8- G concentration was higher while beta-carotene concentration in plasma was lower compared to healthy controls. In patients, there was a trend for an inverse correlation between the two parameters $(R=-0.342)$, while for the relation with MDA no such trend was visible [137]. However, in another small-scale study with non-small cell lung cancer $(n=50)$, plasma GPx, SOD and CAT were significantly reduced in patients, but beta-carotene was significantly increased compared to healthy controls in the later stage of the disease $(n=16)$ [138]. The reasons were unclear, though suggesting that in these subjects, the high concentrations of beta-carotene, in conjunction with vitamin $C$ and alpha-tocopherol (with non-significant differences to controls), failed to keep oxidative stress in check, and that other factors were clearly involved in oxidative stress homeostasis. Contrarily, no significant correlation between CRP and plasma carotenoids was found in 78 subjects with prostate cancer [139]. However, MDA was significantly inversely related to lutein and lycopene, though not alpha- and beta-carotene, and circulating carotenoids were lower compared to healthy controls, suggesting that lycopene was a marker of disease progression in these subjects, though not of systemic inflammation. 
In haemodialysis subjects, decreased levels of plasma lycopene were associated rather strongly $(R=-0.5)$ with high MDA plasma concentrations, perhaps as in such patients, lycopene plays a more important role as an antioxidant, or due to the dietary restrictions, though this was not further investigated [140]. In a study with painters exposed to solvents known to produce oxidative stress and a control group, MDA was inversely related to both lycopene and beta-carotene ( $R$ both around -0.3, Table 3, [141]), and this was also associated with lower GSH and higher SOD and CAT, though no correlations were given for the latter.

Similar as for markers of ROS such as MDA and F2-isoprostanes, studies-especially with non-healthy subjects-have highlighted that low carotenoid status is often related to low oxidative stress defence. In a small-scale study with 40 sickle cell patients, it was shown that compared to controls, subjects had lower circulating beta-carotene concentrations, together with lower SOD and GPx ([142], Table 3), by about one-third. Indeed, sickle cell patients may be more prone to ROS, as the erythrocyte membrane in sickle cells is known to produce more hydroxyl radicals from hydrogen peroxide than in healthy cells, caused by an iron-catalysed Haber-Weiss reaction [143]. Thus, such subjects could be an interesting group to study when investigating relations between oxidative stress and dietary antioxidants. Unfortunately, in this study, intake of carotenoids was not monitored.

In another small-scale study [144], increased inflammation was found in 43 subjects with active Crohn's disease (CD), as indicated by high levels of plasma TNF- $\alpha$ and CRP (Table 3), compared with healthy controls. Also, MDA was significantly increased, while GPx in active patients was significantly upregulated, possibly a consequence of the higher MDA. Beta-carotene or total carotenoids, though determined somewhat imprecisely by spectrophotometry, were reduced in active patients versus controls, down approximately by one-third, though this may have been a direct consequence of the reduced dietary intake, as subjects with active $C D$ have to follow a regimen low in fruits and vegetables. It is, thus, rather likely that the decreased ratio of antioxidants to increased ROS is a consequence of the acute inflammation, and not of reduced antioxidant intake from the diet. Also, rather likely the cause of inflammation, children with otitis media and tonsillitis showed significantly lower concentrations of plasma carotenoids and higher MDA compared to healthy ones [145].

\subsection{Studies with Rather Healthy Subjects}

It may occur that no or even positive correlations between circulating carotenoids and markers or ROS in specific cases may be encountered in healthy subjects, where less severe oxidative stress is to be expected and kept better in check by the body's own antioxidant defence mechanisms, including antioxidant enzymes and other antioxidants circulating compounds such as GSH and uric acid [146]. For example, in a small-scale study comparing healthy vegetarians versus healthy omnivores, though carotenoid intake was higher in vegetarians, several antioxidant markers in plasma (i.e., FRAP, SOD, GPx, GST, GSH) did not differ significantly between both groups. Furthermore, in multilinear regression analysis, no significant association between carotenoid plasma levels and antioxidant markers was found [147], suggesting that in such subjects, homeostasis of oxidative stress was well balanced.

Likewise, in a more large-scale, cross-sectional study by Kim et al. [148] with about 1200 Korean participants (partly healthy, partly self-reported to be under oxidative stress), diet quality was assessed by the food score (RFS), and plasma carotenoids as well as MDA in blood and urine were determined. Interestingly, though urinary MDA and zeaxanthin were negatively associated, all other plasma carotenoids were positively associated with erythrocyte MDA, with no significant correlation in plasma. The reason for this is not entirely clear, but as erythrocytes are very vulnerable to oxidative stress, a high concentration of carotenoids may be a prerequisite to balance such a high concentration of MDA in erythrocytes, and that high MDA is attempted to be matched by circulating antioxidants. Also, no association between MDA and plasma beta-carotene was found in a small case-control study of pregnant smoking women (20 subjects, 20 controls), possibly due to the high variability of concentrations [149], and such very small-scale studies may not be too insightful. 
Some investigations focussed on elderly populations to study the relation between oxidative stress and antioxidants. In a study with about 200 Thai elderly subjects, a rather strong correlation between MDA and lycopene was found ( $r=-0.88,[150])$, which is interesting, as in Western cultures, lycopene may rather be associated with ketchup, pasta and fast food consumption [151]. However, this may not be the case for this population, where perhaps grapefruits and tomatoes and other non-fast-food sources are assumed to be the major source of lycopene. Of note, the median plasma concentration of lycopene with $0.2-0.25 \mu \mathrm{M}$, was rather low compared to Western cultures [8].

Further studies have focussed on lycopene. In a longitudinal study in the US by Rink et al. [152], healthy premenopausal women showing higher beta-carotene, beta-cryptoxanthin and lutein due to the higher dietary intakes also had lower plasma F2-isoprostane concentrations, while the intake of lycopene was even slightly positively associated with F2-isoprostanes, in line with less healthy eating patterns being associated with lycopene. This is supported by another larger cross-sectional study on $>1500$ subjects aged 50 or older, from different European countries, where lycopene positively correlated with MDA [153]. The authors speculated that this was related to Western lifestyle habits, and indeed it was discussed that lycopene, which is mostly found in tomato products, could be increased by a diet rich in convenience foods such as ketchup, pizza and pasta sauce [151]. Interestingly, in the same study, alpha-tocopherol was negatively associated with MDA, which is rather more expected. In another study investigating dietary intake between two cities in Italy and the UK, healthy subjects in Italy had higher circulating beta-carotene concentrations ( 4.74 versus $2.85 \mu \mathrm{M}$ ), and also significantly lower conjugated dienes and lipid peroxides compared to subjects in the UK [154], though many dietary and non-dietary confounders could have contributed to this finding.

Indeed, life-style factors other than diet have been related to oxidative stress. In another cross-sectional study in healthy women where oxidative stress was increased by taking oral contraceptives as determined by increased plasma copper concentrations, lipid peroxides were significantly increased in this group compared to women not using them, and this was associated with a 39\% lower concentration of plasma beta-carotene. However, no effect on oxLDL related to atherosclerosis could be seen [155], which may require more time to be altered.

Interestingly, even depression symptoms were related to ROS, as already emphasized earlier [156]. For example, in a cross-sectional study with 75 women, depression was associated with increased serum lipid peroxide levels, which in turn were correlated significantly with lower individual carotenoid concentrations [157]. Similarly, in a study with almost 1400 healthy elderly (59-71 y), lower carotenoid plasma concentrations were associated with lower cognitive performance, though not with MDA, GPx and SOD. Thus, other parameters such as vessel function may have played a role [158].

\subsection{Studies with Hard Endpoints}

Perhaps the strongest evidence is the relation not only to markers of oxidative stress but to rather hard endpoints, i.e., morbidity and mortality related to diseases characterized by oxidative stress and also low-grade chronic inflammation, such as diabetes [159], the metabolic syndrome [94] or certain types of cancer [160]. Since these diseases are often discussed in relation to the antioxidant activity of the diet, including carotenoids, they will be discussed in brief in this chapter.

Hamer and Chida [161] conducted an interesting meta-analysis, based on nine prospective cohort studies, investigating antioxidant intake per group and T2D risk, including close to 170,000 subjects followed for over 13 years. It was found that higher carotenoid plasma levels/intake (the latter self-reported) were associated with a reduced risk of T2D (by 24\%). Lycopene, though only based on two studies, had no significant effect, and neither had vitamin $\mathrm{C}$ and flavonoids, though higher levels of vitamin $\mathrm{E}$ had. 
In another cross-sectional meta-analysis focusing on the metabolic syndrome, an inverse association between total plasma carotenoids and metabolic syndrome was found. Subjects with highest total circulating carotenoids had a $24 \%$ reduced risk for developing metabolic syndrome. Interestingly, also individual carotenoids were included, and significant associations were found for beta-carotene, lycopene, alpha-carotene and beta-cryptoxanthin [20]. Especially anti-atherosclerotic properties were emphasized as potential explanations.

The NHANES III study, including $>13,000$ subjects, also found that plasma carotenoid concentrations correlated with all-cause mortality, though effects differed according to carotenoid type [162]. Indeed, for lycopene, the middle two quartiles showed lowest all-cause mortality, though the strongest predictor of high all-cause mortality were subjects with lowest serum lycopene, followed by total carotenoid concentration, again likely as lycopene may serve as a marker for a non-healthy, Western-type diet. Furthermore, though all-cause mortality was reduced until achieving plasma concentrations of approximately $1000 \mathrm{nM}$; higher concentrations were not associated with stronger effects.

In another study with 1200 elderly Europeans by Buijsse et al. [19], plasma beta-carotene was significantly associated with a decreased risk of all-cause mortality (by about $20 \%$ for an increment of $0.39 \mu \mathrm{M})$. In a likewise included meta-analysis with over 4000 subjects, higher carotene status was associated with a decreased mortality by about $28 \%$ in the elderly, while vitamin E did not show a significant effect. Anti-inflammatory effects such as on CRP were speculated to be related to these observations. An updated meta-analysis of prospective cohort studies, investigating both the relation of circulating beta-carotene and dietary intake, with approximately 25,000 and 150,000 participants, respectively, came to the same conclusion, with all-cause mortality being reduced by $17 \%$ and $31 \%$, respectively [163]. A recent study based on the ATBC study also showed that subjects $(n=29,000$, followed for $31 \mathrm{y}$ ) with higher circulating concentrations of beta-carotene had an approximately $19 \%$ lower all-cause mortality [164]. However, in these observational studies, no further associations with markers of oxidative stress or inflammation were investigated or reported. Thus, though as with other observational studies, many confounding factors exist which are not easy to account for, these meta-analyses and large-scale prospective studies add largely to the body of evidence supporting the relationship between the intake of carotenoids via fruits and vegetables and their circulating levels, at least as a marker for total mortality. 
Table 3. Markers of oxidative stress in human observational studies.

\begin{tabular}{|c|c|c|c|c|c|}
\hline Outcome Measured & Study Design & Participants & Findings & Comment & Ref. \\
\hline \multicolumn{6}{|c|}{ Hard Endpoints (Mortality and Morbidity) } \\
\hline $\begin{array}{l}\text { Type } 2 \text { diabetes (T2D) } \\
\text { incidence }\end{array}$ & $\begin{array}{l}\text { Meta-analysis of nine } \\
\text { prospective cohort studies, } \\
\text { dietary intake and plasma } \\
\text { conc. of carotenoids }\end{array}$ & $\begin{array}{c}N=140,000, \text { mean follow up } \\
13 \mathrm{y}\end{array}$ & $\begin{array}{l}\text { Sign. inverse assoc. with total plasma } \\
\text { carotenoid and T2D, RR }=0.761 \\
(0.585-0.990)\end{array}$ & $\begin{array}{l}\text { Antioxidants as index of } \\
\text { oxidative damage/ox. capacity }\end{array}$ & [161] \\
\hline Metabolic syndrome (MetS) & $\begin{array}{l}\text { Meta-analysis of } 11 \\
\text { cross-sectional studies of total } \\
\text { plasma carotenoids and MetS }\end{array}$ & $N=45,000$ subjects & $\begin{array}{l}\text { inverse assoc. } \\
\text { between total carotenoids \& MetS (OR } \\
0.66 \text {; } 95 \% \text { CI, } 0.56-0.78 \text { ). Sig. assoc. for } \\
\text { beta-CAR, alpha-CAR and beta-CRY } \\
\text { and LYC }\end{array}$ & $\begin{array}{l}\text { Anti-atherosclerotic properties of } \\
\text { carotenoids emphasized }\end{array}$ & [20] \\
\hline All-cause mortality & $\begin{array}{c}\text { Meta-analysis of prospective } \\
\text { cohort studies and carotene } \\
\text { plasma levels }\end{array}$ & $\begin{array}{l}N=>4000 \text { elderly men and } \\
\text { women Follow-up: } 10 \mathrm{y}\end{array}$ & $\begin{array}{l}\text { Higher carotene plasma levels sign. } \\
\text { associated with lower mortality, by } 38 \% \text { : } \\
\text { RR }=0.72(0.59 ; 0.87)\end{array}$ & $\begin{array}{l}\text { Relation to inflammation and } \\
\text { CRP discussed as potential cause }\end{array}$ & [19] \\
\hline All-cause mortality & $\begin{array}{c}\text { Meta-analysis of prospective } \\
\text { cohort studies and beta-CAR } \\
\text { dietary intake and plasma } \\
\text { conc. }\end{array}$ & $\begin{array}{l}N=150,000 \text { (intake) } ; N= \\
25,000 \text { (plasma) participants, } \\
2-26 \text { y follow up }\end{array}$ & $\begin{array}{c}\text { Circulating: Highest vs. lowest group } \\
\text { had lower risk of total mortality }(\mathrm{RR}= \\
0.69,95 \% \mathrm{CI}: 0.59-0.80) \text {. Intake: } \mathrm{RR}= \\
0.83(0.78-0.88) .\end{array}$ & $\begin{array}{l}\text { Causes discussed include effects } \\
\text { on immune system, antioxidant } \\
\text { function andvitamin A }\end{array}$ & [163] \\
\hline All-cause mortality & $\begin{array}{l}\text { Prospective cohort study of } \\
\text { serum beta-CAR and overall } \\
\text { and cause-specific mortality }\end{array}$ & $N=29,000$, follow up $31 \mathrm{y}$ & $\begin{array}{c}\text { Men with higher serum beta-CAR had } \\
\text { sig. lower all-cause mortality }(\mathrm{HR}= \\
0.81,0.71,0.69 \text {, and } 0.64 \text { for quintile } 2 \\
\text { (Q2)-Q5 versus Q1, resp. }\end{array}$ & $\begin{array}{l}\text { Antiox. activity, arterial wall } \\
\text { protection, vasomotor function, } \\
\text { platelet aggregation and } \\
\text { thrombosis mentioned }\end{array}$ & [164] \\
\hline \multicolumn{6}{|c|}{ Markers Related to ROS, Non-Enzymatic Antioxidant Activity and Lipid Peroxidation } \\
\hline Lipid peroxides & $\begin{array}{l}\text { Case-control, type } 1 \text { diabetes } \\
\text { (T1D) }\end{array}$ & $\begin{array}{c}n=54 \mathrm{~T} 1 \mathrm{D}, \text { and } n=40 \\
\text { healthy controls }\end{array}$ & $\begin{array}{l}\text { T1D subjects had much higher lipid } \\
\text { peroxides (lipid normalized) and MDA } \\
\text { vs. healthy controls, while beta-CAR } \\
\text { was much lower }(<50 \%) \text {. GSH, GPx } \\
\text { were also lower, SOD higher }\end{array}$ & $\begin{array}{l}\text { No direct association, } \\
\text { hyperglycemia-caused oxidative } \\
\text { stress discussed }\end{array}$ & [128] \\
\hline Lipid hydro-peroxides & $\begin{array}{l}\text { Cross sectional study with } \\
\text { healthy subjects }\end{array}$ & $N=36$ healthy subjects & $\begin{array}{c}\text { Inverse assoc. of hydroperoxides with } \\
\text { some carotenoids: alpha-CAR, } \\
\text { beta-CRY, ZEA, not beta-CAR, } \\
\text { LUT, LYC }\end{array}$ & Similar effects for tocopherols & [129] \\
\hline Lipid peroxides $(\mathrm{LOOH})$ & $\begin{array}{l}\text { Cross-sectional study on } \\
\text { depression, LOOH measured } \\
\text { by hemoglobin-methylene } \\
\text { blue method }\end{array}$ & $N=75$ healthy females & $\begin{array}{l}\text { LOOH conc. sign. positively corr. With } \\
\text { depression scores, LOOH sign. } \\
\text { inversely related to beta-CAR plasma } \\
\text { conc. }(r=-0.26)\end{array}$ & $\begin{array}{l}\text { Other carotenoids ns. neg. } \\
\text { associated with LOOH Increased } \\
\text { polymorpho-nuclear leukocytes } \\
\text { in depression? }\end{array}$ & [157] \\
\hline
\end{tabular}


Table 3. Cont.

\begin{tabular}{|c|c|c|c|c|c|}
\hline Outcome Measured & Study Design & Participants & Findings & Comment & Ref. \\
\hline $\begin{array}{l}\text { Conjugated dienes, lipid } \\
\text { peroxides }\end{array}$ & $\begin{array}{l}\text { Cross-sectional, comparison } \\
\text { across two countries }\end{array}$ & $\begin{array}{l}n=22 \text { young adults from } \\
\text { Naples vs. } n=26 \text { from Bristol }\end{array}$ & $\begin{array}{l}\text { beta-CAR } 4.74 \text { vs. } 2.85 \mu \mathrm{M} \text {, associated } \\
\text { with sign. lower conjugated dienes \& } \\
\text { lipid peroxides: } 29.0 \text { vs. } 41.5 \text { and } 1.24 \\
\text { vs. } 4.58 \mu \mathrm{M} \text { resp. }\end{array}$ & $\begin{array}{c}\text { Prone to many confounders such } \\
\text { as physical activity, similar trend } \\
\text { for vitamin E }\end{array}$ & [154] \\
\hline MDA & $\begin{array}{l}\text { Cross-sectional, relation of ox. } \\
\text { stress and cognitive function }\end{array}$ & 1389 healthy elderly, 59-71 y & $\begin{array}{l}\text { Low level of total carotenoids }(<1.86 \\
\mu \mathrm{M}) \text { associated with poor cognitive } \\
\text { performance, not MDA }\end{array}$ & $\begin{array}{l}\text { No effect of other antioxidant } \\
\text { parameters (SOD, GPx) }\end{array}$ & [158] \\
\hline MDA & $\begin{array}{l}\text { Cross-sectional, correlation } \\
\text { between various plasma } \\
\text { carotenoids and MDA in } \\
\text { urine, plasma and } \\
\text { eryhtrocytes }\end{array}$ & $\begin{array}{c}\text { Approximately } N=1200 \\
\text { healthy and self-reported } \\
\text { Korean subjects suffering } \\
\text { from ox. stress }\end{array}$ & $\begin{array}{l}\text { No sign. assoc. with plasma and urine } \\
\text { MDA (except inverse corr. with ZEA, } \\
\text { sign. positive assoc. of erythrocyte } \\
\text { MDA with all carotenoids ( } \beta=0.247 \text { ) }\end{array}$ & $\begin{array}{l}\text { Higher requirement of } \\
\text { erythrocytes for endogenous } \\
\text { antioxidants? }\end{array}$ & [148] \\
\hline MDA & $\begin{array}{c}\text { Cross-sectional, correlation } \\
\text { between LYC and MDA in } \\
\text { plasma }\end{array}$ & $\begin{array}{l}\text { Approximately } N=1560 \\
\text { apparently healthy subjects }\end{array}$ & $\begin{array}{l}\text { Positive sig. association of plasma LYC } \\
\text { \& MDA }(r=0.159)\end{array}$ & $\begin{array}{l}\text { LYC rather diet rich in tomato } \\
\text { products (ketchup, pasta), thus } \\
\text { unhealthy eating patterns }\end{array}$ & [153] \\
\hline MDA & $\begin{array}{l}\text { Case control, painters } \\
\text { exposed to organic solvents, } \\
\text { correlation between plasma } \\
\text { MDA \& LYC and beta-CAR }\end{array}$ & $\begin{array}{c}n=42 \text { subjects and } 28 \\
\text { controls }\end{array}$ & $\begin{array}{l}\text { Sign. correlation between MDA \& LYC } \\
\qquad(r=-0.26 ; \& \text { MDA \& beta-CAR } \\
(r=-0.27)\end{array}$ & $\begin{array}{l}\text { Also, lower GSH, higher SOD } \\
\text { and CAT in exposed group } \\
\text { though corr. with carotenoids not } \\
\text { specified }\end{array}$ & [141] \\
\hline MDA & $\begin{array}{l}\text { Case control study, with } \\
\text { multiple sclerosis (MS) } \\
\text { subjects }\end{array}$ & $\begin{array}{l}n=24 \text { subjects, } 24 \text { gender } \\
\text { and age matched controls }\end{array}$ & $\begin{array}{l}\text { inverse correlation between serum } \\
\text { levels of beta-CAR and MDA ( } r=-0.83) \\
\text { in patients }\end{array}$ & $\begin{array}{l}\text { Similar correlation between } \\
\text { ascorbic acid and MDA }\end{array}$ & [165] \\
\hline MDA & $\begin{array}{l}\text { Case-control hemodialysis } \\
\text { subjects versus healthy } \\
\text { controls }\end{array}$ & $\begin{array}{c}n=29 \text { subjects, } n=20 \text { healthy } \\
\text { controls }\end{array}$ & $\begin{array}{l}\text { Lycopene levels correlated with MDA }(r \\
\qquad=-0.50\end{array}$ & $\begin{array}{l}\text { LYC ns. in a more complex } \\
\text { regression model adjusted for age, } \\
\text { gender, CAT, SOD, GSH, GPx }\end{array}$ & [140] \\
\hline MDA & $\begin{array}{l}\text { Case-control, type I diabetic } \\
\text { subjects (T1D) }\end{array}$ & $\begin{array}{c}n=20 \text { children vs. } 22 \text { obese } \\
\text { children vs. } 16 \text { healthy } \\
\text { controls }\end{array}$ & $\begin{array}{l}\text { T1D \& obese children had higher MDA } \\
\text { conc. than controls and beta-CAR was } \\
\text { lower in T1D subjects, but not in obese } \\
\text { where levels were higher than controls }\end{array}$ & $\begin{array}{l}\text { Also, higher lipoperoxides in } \\
\text { obese and T1D children, obese } \\
\text { children had higher GPx, no corr. } \\
\text { analysis done }\end{array}$ & [166] \\
\hline MDA & $\begin{array}{l}\text { Case-control study, smoking } \\
\text { women }\end{array}$ & $\begin{array}{c}n=20 \text { smoking and } 20 \\
\text { non-smoker pregnant women }\end{array}$ & $\begin{array}{l}\text { Lower beta-CAR plasma levels in } \\
\text { smokers (ns.), but MDA not different }\end{array}$ & $\begin{array}{l}\text { High variability, low number } \\
\text { of subjects }\end{array}$ & [149] \\
\hline MDA & $\begin{array}{l}\text { Cross-sectional, Thai healthy } \\
\text { elderly }\end{array}$ & $\begin{array}{c}N=207 \text { healthy subjects aged } \\
60-91 \mathrm{y}\end{array}$ & $\begin{array}{l}\text { Sign. inverse correlation between MDA } \\
\text { and lycopene }(r=-0.88)\end{array}$ & $\begin{array}{l}\text { No sign. corr. with } \alpha \text {-tocopherol. } \\
\text { Smokers \& male had higher MDA } \\
\text { conc. than non-smokers } \\
\text { and females }\end{array}$ & [150] \\
\hline
\end{tabular}


Table 3. Cont

\begin{tabular}{|c|c|c|c|c|c|}
\hline Outcome Measured & Study Design & Participants & Findings & Comment & Ref. \\
\hline MDA & $\begin{array}{l}\text { Case-control, subjects with } \\
\text { acute tonsillitis (AT) vs. acute } \\
\text { otitis media (AOM) }\end{array}$ & $\begin{array}{c}n=23 \text { children with AOM, } 27 \\
\text { with AT and } 29 \text { healthy } \\
\text { control }\end{array}$ & $\begin{array}{l}\text { beta-CAR \& GSH sign. decreased, in } \\
\text { both patient groups, MDA was higher }\end{array}$ & $\begin{array}{l}\text { No direct corr. analysis } \\
\text { carried out }\end{array}$ & [145] \\
\hline $\begin{array}{l}\text { MDA, protein carbonyls, } \\
\text { sialic acid }\end{array}$ & $\begin{array}{l}\text { Case-control study, acute } \\
\text { coronary syndromes (ACS) }\end{array}$ & $\begin{array}{c}n=102 \text { patients with ACS \& } \\
45 \text { controls }\end{array}$ & $\begin{array}{c}\text { MDA and protein carbonyls sign. } \\
\text { increased, total carotenoids decreased } \\
\text { going from unstable angina } \\
\text { pectoris to MI }\end{array}$ & $\begin{array}{l}\text { Sign. corr. of carotenoids to MDA, } \\
\text { protein carbonyls and sialic acid: } \\
r=-0.51,-0.32,-0.22 \text {, resp. }\end{array}$ & [133] \\
\hline $\begin{array}{l}\text { F2-isoprostanes } \\
\text { (8,12-isoprostane } \\
\text { F(2alpha)-VI), SOD }\end{array}$ & $\begin{array}{c}\text { Case-control, subjects with } \\
\text { congestive heart failure } \\
\text { (CHF) }\end{array}$ & $\begin{array}{c}n=30 \text { patients and } n=30 \\
\text { controls }\end{array}$ & $\begin{array}{c}\text { F2-isoprostanes higher in class III than } \\
\text { in class II NYHA patients, inverse corr. } \\
\text { between F2-isoprostanes and plasma } \\
\text { LUT }(r=-0.68) \text {, LYC }(r=-0.61) \text {, ZEA } \\
(\mathrm{r}=-0.59) \text {, alpha-CAR }(r= \\
-0.44), \text { beta-CAR }(r=-0.41) \text {, and SOD } \\
(r=-0.42) \text { in patients }\end{array}$ & Similar corr. with vitamin C, E, A & [167] \\
\hline $\begin{array}{l}\text { F2-isoprostanes } \\
(8 \text {-iso-PGF2 } \alpha)\end{array}$ & $\begin{array}{c}\text { Cross-sectional, correlation } \\
\text { between F2-isoprostanes in } \\
\text { urine and plasma and tissue } \\
\text { carotenoids }\end{array}$ & $\begin{array}{c}N=69 \text { patients at risk of liver } \\
\text { cancer }\end{array}$ & $\begin{array}{l}\text { Neg. sign. correlation of plasma } \\
\text { beta-CAR and F2-isoprostanes }\end{array}$ & $\begin{array}{l}\text { Also neg. correlations with LYC } \\
\text { and LUT, but ns., same for tissue } \\
\text { carotenoids }\end{array}$ & [135] \\
\hline F2-isoprostanes & $\begin{array}{l}\text { Longitudinal study, FFQ and } \\
\text { plasma carotenoids as well as } \\
\text { free plasma F2-isoprostanes }\end{array}$ & $\begin{array}{l}\text { Healthy premenopausal } \\
\text { women studied over } 2 \text { cycles } \\
\qquad(N=258)\end{array}$ & $\begin{array}{l}\text { Higher beta-CAR, beta-CRY and LUT } \\
\text { due to higher dietary intakes also had } \\
\text { lower plasma F2-isoprostane conc., LYC } \\
\text { intake slightly pos. associated with } \\
\text { F2-isoprostanes }\end{array}$ & $\begin{array}{l}\text { Ketchup as major dietary source } \\
\text { of LYC; though no direct } \\
\text { associations between } \\
\text { F2-isoprostanes \& } \\
\text { carotenoids given }\end{array}$ & [152] \\
\hline F2-isoprostanes, MDA & $\begin{array}{l}\text { Case-control study with } \\
\text { atherosclerotic patients }\end{array}$ & $\begin{array}{c}n=30 \text { patients and } 62 \text { healthy } \\
\text { controls }\end{array}$ & $\begin{array}{l}\text { Independent of fruit \& vegetable intake, } \\
\text { sign. lower plasma levels of all } \\
\text { carotenoids except beta-CRY vs, } \\
\text { controls. Plasma F2- isoprostane } \\
\text { doubled; MDA increased one-third }\end{array}$ & $\begin{array}{l}\text { Similar fruit and vegetable intake } \\
\text { between groups }\end{array}$ & [127] \\
\hline $\begin{array}{c}\text { F2-isoprostanes } \\
\text { (15-isoprostane F2t) }\end{array}$ & $\begin{array}{l}\text { Case-control study of lung } \\
\text { cancer and urinary } \\
15 \text {-isoprostane F2t }\end{array}$ & $\begin{aligned} n= & 207 \text { subjects and } \\
& 414 \text { controls }\end{aligned}$ & $\begin{array}{l}\text { Lower levels of carotenoids, higher } \\
\text { levels of F2-isoprostanes pos. assoc. } \\
\text { with higher lung cancer risk }\end{array}$ & $\begin{array}{l}\text { No direct corr. shown but } \\
\text { assumed }\end{array}$ & [136] \\
\hline oxLDL, lipid peroxides & $\begin{array}{l}\text { Cross-sectional study with } \\
\text { healthy women using oral } \\
\text { contraceptives (OCs) vs. non- } \\
\text { contraception users (NCU) } \\
\text { and intrauterine (hormonal } \\
\text { and copper) device users } \\
\text { (IUD) }\end{array}$ & $N=897$ healthy volunteers & $\begin{array}{l}\text { Sign. increase in lipid peroxides in OCU } \\
\text { compared to NCU and IUD users and } \\
\text { lower beta-CAR conc. ( } 39 \% \text { lower), no } \\
\text { effect on oxLDL }\end{array}$ & $\begin{array}{c}\text { Adjusted for smoking, systolic BP } \\
\text { and BMI; estrogen intake } \\
\text { associated with sign. altered ROS, } \\
\text { likely due to increased Cu conc. } \\
\text { in plasma }\end{array}$ & [155] \\
\hline
\end{tabular}


Table 3. Cont

\begin{tabular}{|c|c|c|c|c|c|}
\hline Outcome Measured & Study Design & Participants & Findings & Comment & Ref. \\
\hline 8-OH-dG, MDA & $\begin{array}{l}\text { Case-control with } \\
\text { lung-cancer subjects }\end{array}$ & $\begin{array}{c}n=39 \text { patients with lung } \\
\text { cancer and } 31 \text { healthy } \\
\text { controls }\end{array}$ & $\begin{array}{c}\text { Trend for higher beta-CAR correlated } \\
\text { with lower 8-OH-dG in patients }(p= \\
0.065), \text { no trend for MDA }\end{array}$ & $\begin{array}{l}\text { MDA pos. cor. with 8-OH-dG, } \\
\text { but lower variability, thus ns. } \\
\text { correlated with beta-CAR }\end{array}$ & [137] \\
\hline \multicolumn{6}{|c|}{ Markers Related to Enzymatic Antioxidant Defence } \\
\hline GPx, SOD, GST, GSH, FRAP & $\begin{array}{l}\text { Cross-sectional, being } \\
\text { vegetarian }\end{array}$ & $\begin{array}{c}n=31 \text { vegetarians (including } \\
\text { six vegans) and } 58 \text { omnivores, } \\
\text { non-smokers }\end{array}$ & $\begin{array}{l}\text { Vegetarians } \sim 15 \% \text { higher levels of } \\
\text { plasma carotenoids vs. omnivores, incl. } \\
\text { LUT, alpha-CRY, LYC, alpha-CAR, } \\
\text { beta-CAR (latter } 3 \text { ns). Levels of all } \\
\text { antiox. markers similar between groups }\end{array}$ & $\begin{array}{l}\text { No sign. association between } \\
\text { carotene and antiox. makers in } \\
\text { multilinear regression models }\end{array}$ & [147] \\
\hline SOD and GPx & $\begin{array}{l}\text { Cross-sectional study on } \\
\text { sickle cell patients }\end{array}$ & $\begin{array}{l}n=26 \text { Nigerian and } 30 \\
\text { British subjects and healthy } \\
\quad \text { controls }(30,15)\end{array}$ & $\begin{array}{l}\text { Higher beta-CAR in controls vs. } \\
\text { subjects, together with higher plasma } \\
\text { SOD and GPx, approximately } 30 \% \\
\text { increase for all }\end{array}$ & $\begin{array}{l}\text { Small-scale study, high variability } \\
\text { between subjects }\end{array}$ & [142] \\
\hline $\begin{array}{l}\text { SOD, GPx and xanthine } \\
\text { oxidase }\end{array}$ & $\begin{array}{l}\text { Case-control study in newly } \\
\text { diagnosed non-small cell } \\
\text { lung cancer subjects }\end{array}$ & $\begin{array}{l}\text { Stage III (IIIA + IIIB, } n=27) \\
\text { and stage IV }(n=23) \text { and } 16 \\
\text { healthy controls }\end{array}$ & $\begin{array}{l}\text { GPx, SOD, CAT sign. reduced, XO } \\
\text { activity sign. elevated in NSCLC } \\
\text { patients, beta-CAR sign. increased in } \\
\text { advanced stage compared to healthy } \\
\text { controls (!) }\end{array}$ & $\begin{array}{c}\text { Unclear why advanced NSCLC } \\
\text { subjects had higher beta-CAR } \\
\text { levels (supplements?), } \\
\text { no corr. given }\end{array}$ & [138] \\
\hline CAT, GPx, GSH, MDA & $\begin{array}{l}\text { Case-control, patients with } \\
\text { Pemphigus Vulgaris (PV) }\end{array}$ & $\begin{array}{c}n=18 \text { non-smoking PV and } \\
\text { equal number of age- and } \\
\text { gender-matched, healthy } \\
\text { control subjects }\end{array}$ & $\begin{array}{l}\text { Sign. lower conc. of plasma antiox. } \\
\text { vitamins (E, A, and beta-CAR), lower } \\
\text { antiox. enzymes (CAT in RBC and } \\
\text { plasma, GSH-Px in RBC, and resp. GSH } \\
\text { activities in both RBC and plasma, } \\
\text { increased MDA (RBC, plasma) }\end{array}$ & Dietary intake not determined & [168] \\
\hline $\begin{array}{l}\text { SOD, CAT, GPx, GSH, } \\
\text { conjugated dienes }\end{array}$ & $\begin{array}{l}\text { Case-control, patients with } \\
\text { cardiogenic shock that } \\
\text { complicate acute myocardial } \\
\text { infarction (AMI) }\end{array}$ & $\begin{array}{c}n=25 \text { patients with AMI vs. } \\
n=25 \text { healthy controls }\end{array}$ & $\begin{array}{c}\text { Patients had higher MDA, conjugated } \\
\text { dienes and reduced activities/conc. of } \\
\text { erythrocyte antiox. enzymes: SOD, } \\
\text { CAT, GPx, erythrocyte and in plasma } \\
\text { GSH, and beta-CAR }\end{array}$ & $\begin{array}{l}\text { No corr. analysis between } \\
\text { carotenoids \& markers of } \\
\text { ox. stress }\end{array}$ & [131] \\
\hline \multicolumn{6}{|c|}{ Markers Related to Inflammation } \\
\hline CRP, MDA & $\begin{array}{l}\text { Cross sectional, various } \\
\text { complications, i.e., prostate } \\
\text { hyperplasia and prostate } \\
\text { cancer (PC) }\end{array}$ & $\begin{array}{c}n=14 \text { healthy controls, } n=20 \\
\text { patients with benign prostate } \\
\text { hyperplasia, } n=40 \text { with local, } \\
n=38 \text { with metastatic (PC) }\end{array}$ & $\begin{array}{l}\text { In PC patients: CRP not corr. with } \\
\text { antioxidants or MDA. Neg. corr. } \\
\text { Between MDA and LUT ( } r=-0.263) \\
\text { and LYC ( } r=-0.269) \text {. Lower conc. of } \\
\text { carotenoids in patients vs. controls }\end{array}$ & $\begin{array}{l}\text { No correlation with alpha- and } \\
\text { beta-carotene }\end{array}$ & [139] \\
\hline
\end{tabular}


Table 3. Cont.

\begin{tabular}{|c|c|c|c|c|c|}
\hline Outcome Measured & Study Design & Participants & Findings & Comment & Ref. \\
\hline CRP & Case-control study for stroke & $\begin{array}{c}n=68 \text { patients with acute } \\
\text { ischemic stroke vs. } 41 \text { normal } \\
\text { controls }\end{array}$ & $\begin{array}{l}\text { Plasma LYC, alpha- and beta-CAR conc. } \\
\text { lower and conc. of inflamm. markers } \\
\text { higher in patients with acute ischemic } \\
\text { stroke vs. normal controls. alpha- and } \\
\text { beta-CAR and LYC in patients with } \\
\text { stroke neg. associated with CRP } \\
(R=-0.29,-0.41,-0.28 \text { resp. })\end{array}$ & na & [134] \\
\hline CRP, TNF- $\alpha, \mathrm{MDA}$ & $\begin{array}{l}\text { Case-control, Crohn's disease } \\
\text { (CD) }\end{array}$ & $\begin{array}{c}n=16 \text { active CD patients, } 27 \\
\text { clinically stable patients, and } \\
15 \text { healthy controls }\end{array}$ & $\begin{array}{l}\text { beta-CAR levels in sera from all CD } \\
\text { patients lower than controls (down to } \\
\text { One-third in active CD compared to } \\
\text { controls). Patients with active CD had } \\
\text { higher GPx }(30 \%), T N F-\alpha(2 \times), \text { MDA } \\
(2 \times) \text { and CRP }(20 \times) \text { than controls }\end{array}$ & $\begin{array}{l}\text { Conc. unclear, spectrophot. not } \\
\text { specific for } \beta \text {-CAR, rather sum of } \\
\text { carotenoids, no corr. given, } \\
\text { decreased ratio of antioxidants: } \\
\text { ROS rather result of acute } \\
\text { inflammation, not due to } \\
\text { lower intake }\end{array}$ & [144] \\
\hline
\end{tabular}




\subsection{Conclusions}

In summary, there are many studies suggesting that especially in non-healthy subjects, elevated markers of oxidative stress are often associated with decreased levels of circulating antioxidants, including carotenoids. Studies in healthy subjects suggest fewer clear relations. However, it is often unclear whether a reduced dietary intake of carotenoids could contribute to this observation, as it is often not assessed. Though total carotenoids may be the best marker for the intake of a mixed fruit/vegetable diet, also individual carotenoids have been investigated. In Western cultures, lycopene may be an exception, as its intake may also be high on diets otherwise low in antioxidants, due to the consumption of products high in ketchup, pizza and pasta, i.e., convenient foods. Interestingly, even when taking into account the dietary intake of carotenoids, non-healthy subjects have shown lower concentrations of circulating carotenoids, suggesting either incomplete absorption, increased excretion or a more rapid degradation/metabolism.

Thus, whether dietary antioxidant levels, including carotenoids are rather a consequence of a disease, or also causally related to these, cannot be clearly deduced from such studies. More large-scale studies, taking into account a more detailed view on dietary carotenoid intake, and including validated as well as auxiliary markers, and possibly novel markers based on -omics techniques and studies with hard endpoints are much needed.

\section{Results from Human Intervention Trials}

Unlike observational studies, intervention trials are able to establish causality, but are more costly and difficult to conduct, especially for prolonged periods of time. Two major types of studies may be differentiated - those employing whole foods rich in carotenoids and those in which supplements dietary supplements are administered. While prescribing a regimen with carotenoid-rich foods is possibly more applicable to study realistically the effects of carotenoids in just such foods, it is difficult to ascribe any observed effects merely to carotenoids, as food items rich in carotenoids (Table 1) are likewise rich in dietary confounders, i.e., compounds with somewhat similar health benefits, including dietary fibre, polyphenols or other phytochemicals, vitamin C, vitamin E, and minerals, and it is very difficult if not impossible to take these confounders fully into account. When giving supplements, it may have to be considered that the matrix is not comparable to fruits and vegetables rich in carotenoids, i.e., being often lower in dietary lipids which may aid in the bioavailability of carotenoids, though normally also containing less dietary fibre, which may hamper carotenoid absorption $[169,170]$. In addition, the dosing and usual single-daily intake may differ from normal food items, where smaller doses are taken in, distributed among 3-5 portions of fruits/vegetables per day, and result in different kinetics. For example, for several carotenoids, plateau effects in plasma were described for higher doses (i.e., >10-20 mg over prolonged periods of intake) [8], and this may differ for smaller doses, being more continuously ingested. As a consequence, both study types combined may yield the most complete insights into the effects of carotenoids on oxidative stress and inflammation, as either type of study alone bears its limitations-either too many confounding factors or unrealistic matrix and dosing/kinetics when compared to normal food items.

\subsection{Studies with Non-Healthy Subjects}

Among the most studied carotenoids is beta-carotene, which also includes studies with supplements. In a beta-carotene intervention trial with cystic fibrosis subjects [171], a significant increase of LDL lag-time after 3 months of supplementation with $0.5 \mathrm{mg} / \mathrm{kg}$ as water miscible beadlets, together with a significant decrease of plasma MDA (regression of $-0.40 \mu \mathrm{M}$ MDA per $\mu$ M beta-carotene) was observed, suggesting that the low levels observed prior to intervention $(0.02 \mu \mathrm{M})$ can be increased (to $0.31 \mu \mathrm{M}$ ) with supplementation, and can improve markers of oxidative stress. In another study on cystic fibrosis, patients received $1 \mathrm{mg} / \mathrm{kg}$ body weight beta-carotene per day (maximum $50 \mathrm{mg}$ ) for 3 months. When compared to the placebo group, non-significant improvements in plasma ABTS 
and significantly lower levels of MDA were observed; however, the latter was not maintained when continuing on $10 \mathrm{mg} / \mathrm{d}$ beta-carotene supplements [172]. This suggests that in such subjects, lower doses are not efficient, and overall, improvements upon supplementation were somewhat marginal. A somewhat more positive effect was found when supplementing beta-carotene $(60 \mathrm{mg} / \mathrm{d})$ for 3 weeks to T2D subjects, resulting in reduced MDA and enhanced stability of LDL against copper induced oxidation [173]. These studies suggest that efficient doses have to be comparatively high in such subjects, which is difficult to reach with a normal mixed diet.

As smokers are also subjects presumably prone to oxidative stress, several studies have investigated the effect of carotenoid intervention on smokers. In a small-scale study, $20 \mathrm{mg}$ of beta-carotene was given to smokers and to non-smokers every day for 4 weeks, and lipid peroxides were measured via breath [174]. While lipid peroxides were significantly reduced in smokers, supplementation had no effect on healthy non-smokers. In another intervention trial with 39 healthy smokers receiving either 5, 20 or $40 \mathrm{mg}$ astaxanthin per day for 3 weeks, plasma levels of F2-ispoprostane were especially reduced in a time- and dose-dependent fashion [175]. However, the study lacked a placebo group, and for other parameters investigated (SOD, antioxidant capacity, MDA), there was generally no clear time and dose-dependency. Astaxanthin is of interest, as it has been proposed as a safe and especially strong antioxidant, as it was found to have stronger antioxidant capacity compared to other carotenoids in some in vitro studies [176]. When moving from supplements to a regular diet, in a rather very small-scale study (11 subjects per group) with age- and gender-matched controls [177], plasma carotenoids increased in smokers by $23 \%$ and $11 \%$ in non-smokers, following a 2 week diet rich in fruits and vegetables. This was accompanied by an increase in copper-mediated LDL resistance to oxidation, which increased by $14 \%$ in smokers and by $28 \%$ in non-smokers, demonstrating that even in such small-scale and short-term studies, positive effects may be measurable. The results also suggest that from a mixed diet rich in fruits and vegetables, carotenoid intake in such form does not have to be as high as in the supplementation trial to show positive effects. Of course, effects may not be attributable to carotenoids alone, but also to other constituents in the diet such as dietary fibre or polyphenols, or even less healthy food items which were left out instead, a fact that is often overlooked.

As with observational studies, as cognitive performance and diseases have been both related to carotenoid intake and oxidative stress, a few studies have investigated whether carotenoid supplementation can benefit oxidative stress in such subjects. In a study with 21 Alzheimer's disease subjects versus 16 healthy age- and gender-matched controls, no effects on FRAP, F2-isoprostanes, and lipid peroxidation were found (Table 4) following 6 months of supplementation with $10 \mathrm{mg}$ meso-zeaxanthin, $2 \mathrm{mg}$ zeaxanthin and $10 \mathrm{mg}$ lutein [178] per day, even though disease subjects showed lower FRAP and higher lipid peroxidation concentrations compared to controls, and the latter marker was well related to cognitive performance. It is possible that the combination of carotenoids, which could be more suited for age-related macular degeneration, and missing carotenes was not optimal against oxidative stress, though this remains speculative.

Viral infections have also been considered to be benefit from carotenoid supplementation, due to their relation to inflammation. In another small-scale study with 60 hepatitis $C$ virus-related liver cirrhosis subjects receiving red palm oil, being rich in beta-carotene and total carotenoids (31 mg/100 g, [179]), supplementing the diet for 8 weeks reduced erythrocyte MDA and urinary F2-isoprostane output (by about 30\% compared to baseline), and this effect was stronger than supplementing these subjects with vitamin E [180]. In another study with subjects having oxidative stress (though not more closely defined), an interesting intervention with both supplements and food items was carried out [181]. Subjects received either synthetic lycopene $(15 \mathrm{mg} / \mathrm{d}$ for 10 weeks) as a capsule or in form of tomato products ( $200 \mathrm{~g} / \mathrm{d}$, approximately equivalent in the amount of lycopene). When compared to a placebo group, subjects showed reduced MDA and enhanced SOD, CAT, GPx and GSH. It is interesting that both the supplement and the food items had similar strong effects, with the supplement producing slightly but non-significant stronger results, though the authors did not perform a detailed statistical analysis of the observed changes between study arms. This study strongly indicates that the 
observed effects were truly due to lycopene, and could be achieved not only via food items, but also in form of a capsule. Tomato products were also tested in another study in hypertensive subjects [182]. In this study, MDA was significantly reduced following 60 days of tomato consumption $(200 \mathrm{~g} / \mathrm{d})$, while antioxidant enzymes including SOD, GPX as well as GSH were significantly increased. Markers tended to improve with prolonged intake of tomato products. However, lycopene intake was not estimated (but was likely to be around $10-20 \mathrm{mg} / \mathrm{d}$ ), and a clear control group was missing.

Finally, lycopene has been advocated against hormonal related prostate cancer, as higher intake of tomatoes was found to be associated with reduced incidence of prostate cancer, though results are still somewhat controversial $[183,184]$. In a study with African veterans with prostate cancer or prostate hyperplasia, supplementation with tomato oleorosin for 3 weeks (delivering $30 \mathrm{mg} / \mathrm{d}$ of lycopene) did not reduce plasma MDA or tissue 8-OH-dG, compared to a control group [185]. However, there was a trend toward lower concentrations of both markers, though the variability of the concentrations was quite large, and perhaps the intervention time was too short to change tissue concentrations, though the samples size was not so small (105 subjects).

\subsection{Studies with Healthy Subjects}

As in observational studies, it is expected that measurable effects in healthy studies upon intervention may be more limited compared to studies in subjects with chronic diseases and possibly elevated oxidative stress. Again, beta-carotene is among the most frequently studied carotenoids. In an interesting, dose-escalating study with healthy subjects receiving either 5, 10, 20 or $40 \mathrm{mg}$ beta-carotene per day as a supplement for 5 weeks, MDA was only reduced in the highest group. Uric acid, also an endogenous antioxidant, as well as antioxidant capacity (TEAC), decreased in all groups [186], though not significantly for TEAC and not for all groups for uric acid, perhaps as a result of reduced oxidative stress requiring less endogenous antioxidants. In a study designed to scrutinize the effect of a low versus beta-carotene rich diet, 15 healthy and young subjects underwent a 2 week washout diet low in carotenoids, followed by either 15 or $120 \mathrm{mg}$ beta-carotene per day for 4 weeks, while maintaining the same low-carotenoid diet [187]. Following beta-carotene supplementation, lipid peroxide levels in plasma significantly decreased in both groups, with a correlation between the two $(r$ around -0.60), though neutrophil superoxide production remained unchanged. The results suggest that supplementing huge doses was not more beneficial than supplementing the low dose of beta-carotene, despite plasma concentrations being higher in the beta-carotene rich group ( 8.8 versus $3.4 \mu \mathrm{M})$. When giving beta-carotene in the form of natural food items, low concentrations were also found to be beneficial. In a study with a concentrated and encapsulated food form of carotenoids-fruit juice concentrate-containing approximately $7.5 \mathrm{mg}$ beta-carotene equivalents of total carotenoids, consumed each day for 28 days, improved 8-OH-dG and lipid peroxides in healthy subjects-both in smokers and non-smokers [188] — by about 21 and 11\%, respectively, a moderate improvement.

Several additional studies have been conducted with other carotenoids, mostly including lutein and lycopene, but also astaxanthin. In an important study, it was aimed to compare various carotenoid supplements in a medium scale study with 175 healthy subjects [189]. Subjects received either $15 \mathrm{mg}$ of lutein, lycopene or beta-carotene per day or a placebo for 3 months. However, no significant effects were measured regarding GSH, SOD, GPx and copper-induced LDL particle stability. Plasma uric acid did likewise not change. This study highlights that in healthy subjects following a normal mixed diet, additional supplementation may not result in additional measurable benefits regarding oxidative stress parameters, at least not during the short-term. 
In another, medium-scale study with 117 healthy, non-smoking subjects, lutein was supplemented for 12 weeks versus a placebo, either at 10 or $20 \mathrm{mg} / \mathrm{d}$. Plasma MDA, ABTS, CRP, SOD, CAT and GPx in plasma were measured [190]. Only MDA, ABTS and CRP changed significantly, and a significant correlation between plasma lutein and CRP $(r=-0.44)$ was found, perhaps as the subjects were healthy and came from a well-educated background with a presumably healthy life-style. Three interesting studies were conducted with new-borns receiving lutein supplementation. In the double-blinded, placebo-controlled study by Perrone [191], at $12 \mathrm{~h}$ and $36 \mathrm{~h}$ after birth, $0.28 \mathrm{mg}$ lutein was given via milk. When compared to the control group $(n=47)$, the new-borns $(n=103)$ supplemented with lutein on the first day postpartum showed enhanced FRAP levels versus the control and non-significantly reduced total hydroperoxides, while advanced oxidation protein products (AOPPs) did not change. The same group already conducted an earlier pilot study on 20 term infants, with identical lutein amounts being administered. They found no increase of total hydroperoxides in the group receiving lutein but a significant increase in the control group, as well as a slight but significant increase in FRAP in the group receiving lutein (from 3300 to $3500 \mu \mathrm{M}$ ) versus no change in the control group [192], though individual variability was high. In a similar study with 183 infants below 33 weeks of gestational age, supplementing $210 \mu \mathrm{g} / \mathrm{L}$ carotenoids via their formula, consisting of equal parts of beta-carotene, lutein and lycopene, until 40 weeks post-menstrual age, reduced CRP from approximately 0.4 to $0.2 \mu \mathrm{g} / \mathrm{mL}$ [193], which is possibly of no clinical relevance.

Algae carotenoid studies have especially included astaxanthin. In a small-scale study with 24 healthy subjects (in their mid 40s), $6 \mathrm{mg}$ astaxanthin supplements per day (together with $10 \mathrm{mg} / \mathrm{d}$ sesamine) for 4 weeks each day reduced both mental fatigue and also phosphatidyl-hydroperoxide plasma levels [34], compared to a placebo in this randomized, double-blinded study. It would be worth studying whether improving antioxidant status may also in other situations improve mental and cognitive aspects. In 12 senior subjects receiving either placebo $(n=6)$ or chlorella algae $(8 \mathrm{~g}$ chlorella/d; with $22.9 \mathrm{mg}$ lutein/d) for 2 months [194], phospholipid-hydroperoxides were likewise reduced in erythrocytes and plasma in both groups, with no significant difference between them, possibly as the study was underpowered and subjects were healthy. In a further study including elderly (middle-aged and more senior men, age approximately $56+/-5$ ), astaxanthin was supplemented either at 0,6 or $12 \mathrm{mg} / \mathrm{d}$ for 12 weeks. Serum and erythrocyte lipid peroxides were measured, and compared to the $0 \mathrm{mg} / \mathrm{d}$ group, both groups showed lower lipid peroxides in erythrocytes and serum, with the latter showing a dose-dependency [195]. Thus, supplementing carotenoids to the elderly may show some benefits according to these findings and may deserve more attention.

Again, due its relation to cancer, lycopene supplementation has been studied. In an interesting, dose-escalating study with lycopene in a double-blinded, placebo-controlled study with healthy subjects, either $0,6.5,15$ or $30 \mathrm{mg}$ lycopene was given per day for a total of 8 weeks (following a washout period, [196]). Though a significant decrease in DNA damage in lymphocytes was registered with the highest lycopene dose, as well as reduced 8-OH-dG concentrations in plasma, reductions were rather small (about 10 and 25\%, respectively), possibly as these were already healthy subjects. Likewise, very limited results were observed in a vegetable supplementation trial, where healthy, non-smoking subjects received either 2, 5 or 8 servings of fruits/vegetables per day, for a total of 4 weeks [197]. No DNA strand breaks, changes in plasma MDA, F2-isoprostanes or TEAC were observed, again likely as subjects were healthy and still received a basal diet with at least 2 portions of fruits and vegetables, in combination with a limited intervention time. In a study with LycoRed, a tomato paste concentrate, supplementation over 6 months with $4 \mathrm{mg}$ lycopene per day produced a rather modest reduction of MDA and increase in GSH of about $16 \%$ and $13 \%$, respectively, in healthy postmenopausal women [198]. A comparable product, LYC-O-Mato, given to subjects with slight hypertension (providing $15 \mathrm{mg}$ lycopene/d) likewise produced only a modest reduction of MDA, of about $15 \%$, when given over 8 weeks [199]. 
On the other hand, rather than supplementing additional carotenoids, it was also studied whether removing carotenoids from the diet could have negative effects. Mackinnon et al. [200], removed lycopene from the diet of 23 healthy postmenopausal women for 1 month, reducing lycopene intake from 3.5 to $0.13 \mathrm{mg} / \mathrm{d}$ by reducing tomato and tomato product intake. Though other carotenoids were also significantly reduced in plasma (up to $30 \%$, such as for beta-carotene), lycopene concentrations dropped to about half the original concentration. However, none of the other carotenoid concentrations dropped significantly. This intervention resulted in slightly increased plasma MDA (10\%, not significant) and increased protein oxidation (also non-significant), and reduced SOD and CAT, while GPx significantly increased, possibly as a protective mechanism against the somewhat increased peroxides, suggesting that indeed lycopene may be related to plasma antioxidant activities and ROS. However, tomatoes are also rich in polyphenols and dietary fibre (pectin), and several types of polyphenols [201,202] as well as pectin [203] have been shown to improve antioxidant status in humans when given in an isolated form.

Most studies intervening in diet, however, tried to increase fruit and vegetable intake, and thus, carotenoid consumption. In a study with 37 women at risk of breast cancer but otherwise healthy, the number of fruits/vegetables was increased to 12/day for the time of 2 weeks, and markers of oxidative stress, including 8-OH-DhG in urine and lymphocytes, as well as F2-isoprostanes in plasma, were measured. Changes in xanthophylls were significantly associated $(r=-0.45)$ with lymphocyte 8-OH-dG, but not with other markers, perhaps due to the short intervention time [204], despite the untypical high number of fruit/vegetable portions.

In another study with significantly increased portions of fruits and vegetables, 8-10 servings of fruits and vegetables per day were served either as a diet rich in many different plant foods or low in variety, despite a similar macronutrient content and total amount of phytochemicals. Following these diets for 14 days, the 53 women in each arm showed markedly reduced lymphocyte 8-OH-dG and also reduced F2-isoprostanes in urine (Table 4, [205]). Though carotenoids were merely measured as a marker of adhering to the botanical-rich diet, total carotenoid content of the diets was about 30 and $24 \mathrm{mg} / \mathrm{d}$, respectively, which is markedly higher compared to a more typical consumption of around $12 \mathrm{mg}$ [8]. As changes were more favourable in the more diverse diet, the authors argued that a more diverse array of a smaller number of phytochemicals may be more beneficial than taking in large amounts of fewer phytochemicals. This may point to synergistic effects between the various compounds, or less competitive effects during absorption, and metabolism, which would be less favourable news for supplements based on individual carotenoids.

\subsection{Studies with Hard Endpoints}

The most well-known studies supplementing carotenoids are possibly the ones including beta-carotene, namely, the Alpha-Tocopherol, Beta-Carotene prevention trial (ATBC) and the beta-Carotene and Retinol Efficacy Trial (CARET). The ATBC included 29,000 participants, receiving $20 \mathrm{mg}$ of beta-carotene daily for 5-8 years [206], while the CARET [24] included >18,000 participants, receiving $30 \mathrm{mg}$ of beta-carotene daily for 4 years. Supplements given had a high bioavailability and were water-soluble beadlets, resulting in very high blood concentrations ( 10 times higher compared to typical dietary intake). Unexpectedly, both studies resulted in increased lung cancer incidence in the groups receiving beta-carotene, by about 16\% (ATBC trial) and 28\% (CARET study). In addition, all-cause mortality significantly increased in both intervention groups. These effects were, however, limited to smokers and asbestos workers regarding lung and stomach cancer, and are likely to be only relevant for subjects with lung complications [207]. 
Contrarily, both the Physician's Health Study [208] and the Heart Protection Study [209], where subjects received $50 \mathrm{mg} /$ every other day for 13 years and $20 \mathrm{mg} / \mathrm{d}$ beta-carotene for 5 years, respectively, reported no negative effects. Perhaps the elevated plasma concentrations of beta-carotene may act as a more suitable health marker, which was lower in the latter trials, around 2.2 and $1.22 \mu \mathrm{M}$ serum concentrations of beta-carotene versus 5.6 and $3.8 \mu \mathrm{M}$ in the ATBC and CARET trials, respectively. In addition, a large-scale intervention study in the Chinese province of Linxian [210] (30,000 subjects, mostly non-smokers) reported preventive effects of a supplement containing $15 \mathrm{mg}$ beta-carotene, $30 \mathrm{mg}$ alpha-tocopherol and $50 \mu \mathrm{g}$ selenium (resulting in $1.0 \mu \mathrm{M}$ mean plasma carotenoid concentration), both with respect to stomach cancer and total mortality. It is possible that subjects were marginally deficient at study onset and did benefit from the supplementation of these micronutrients.

Meta-analyses have also been conducted on the topic of carotenoid supplementation. Bjelakovic et al. [211] emphasized that beta-carotene supplementation (alone or in combination with additional antioxidants) was related to increased all-cause mortality/adverse effects in a mixed population. However, these findings are strongly biased by the inclusion of the ATBC and the CARET trials, while other trials did not find negative effects. Thus, such detrimental effects are likely only relevant for high carotenoid doses in subjects with lung complications such as smokers and asbestos workers and especially beta-carotene and emphasize that one should be extremely prudent in summarizing results from meta-analyses and drawing conclusions for the general population.

\subsection{Conclusions}

It is apparent that the positive health effects ascribed to carotenoid intake via fruits and vegetables, observed in rather small-scale studies, and in subjects at increased risk for suffering from chronic oxidative stress and related diseases, such as diabetes, severe obesity or otherwise diseased subjects, are not apparent in large-scale trials with carotenoid supplements and hard endpoints.

Even in studies with healthy subjects, the effects of small-scale studies remain mixed and observed changes in biomarkers related to oxidative stress appear small and may not have a strong clinical significance. On the other hand, the negative effects ascribed to carotenoid supplementation, based on the large-scale ABTS and CARET trials are likely limited to subjects with lung complications such as smokers and asbestos workers, and are only attributable to beta-carotene supplements at high daily doses (20-30 mg or more), resulting in strong increases in carotenoid plasma concentrations ( $>3.5 \mu \mathrm{M})$. 
Table 4. Markers of oxidative stress in human intervention trials.

\begin{tabular}{|c|c|c|c|c|c|c|}
\hline Marker Measured & Study Design & Subjects & Carotenoid Intake & Findings & Comment & Ref. \\
\hline \multicolumn{7}{|c|}{ Supplements } \\
\hline Lipid peroxides & $\begin{array}{c}\text { Randomized } \\
\text { double-blind controlled } \\
\text { trial }\end{array}$ & $\begin{array}{c}n=25 \text { smokers and } 38 \\
\text { non-smokers }\end{array}$ & $\begin{array}{l}20 \text { mg beta-CAR or placebo } \\
\text { daily for } 4 \text { weeks }\end{array}$ & $\begin{array}{l}\text { BPO decreased sign. only in } \\
\text { smokers receiving beta-CAR }\end{array}$ & $\begin{array}{l}\text { No effect in healthy } \\
\text { non-smokers }\end{array}$ & [174] \\
\hline $\begin{array}{l}\text { Total hydro-peroxides } \\
(\mathrm{TH}), \text { advanced } \\
\text { oxidation protein } \\
\text { products (AOPP), FRAP }\end{array}$ & $\begin{array}{c}\text { Randomized controlled, } \\
\text { double-blinded clinical } \\
\text { trial }\end{array}$ & $\begin{array}{l}N=150 \text { new-borns, } 47 \\
\text { controls, } n=103 \\
\text { supple-mented }\end{array}$ & $\begin{array}{l}\text { LUT or placebo at } 6 \mathrm{~h} \text { and } 36 \\
\mathrm{~h} \text { after birth, each } 0.28 \mathrm{mg}\end{array}$ & $\begin{array}{l}\text { No sign. change of TH and } \\
\text { AOPP, enhanced FRAP in } \\
\text { lutein group versus no } \\
\text { change in control group }\end{array}$ & Slight reduction of $\mathrm{TH}$ & [191] \\
\hline Lipid peroxides & $\begin{array}{c}\text { randomised, } \\
\text { double-blind, } \\
\text { placebo-controlled trial }\end{array}$ & $\begin{array}{c}N=30 \text { middle-aged and } \\
\text { senior subjects }\end{array}$ & $\begin{array}{l}\text { 12-week ASX } \\
\text { supple-mentation } \\
\text { (6 } 6 \text { or } 12 \mathrm{mg} / \mathrm{d} \text { ) }\end{array}$ & $\begin{array}{l}\text { Erythrocyte peroxide conc. } \\
\text { lower in ASX groups than in } \\
\text { placebo group (up to } 50 \% \text { ), } \\
\text { in plasma, lower } \\
\text { peroxide levels }\end{array}$ & $\begin{array}{l}\text { Plasma: higher dose more } \\
\text { strongly reduced peroxides, } \\
\text { erythrocytes: comparable } \\
\text { reduction }\end{array}$ & [195] \\
\hline $\begin{array}{l}\text { Phosphatidyl } \\
\text { hydro-peroxide } \\
\text { (PCOOH) }\end{array}$ & $\begin{array}{c}\text { Randomized, } \\
\text { double-blind, } \\
\text { placebo-controlled } \\
\text { cross-over trial }\end{array}$ & $N=24$ healthy subjects & $\begin{array}{l}\text { ASX supplement } 6 \mathrm{mg} / \mathrm{d} \\
\text { (and } 10 \mathrm{mg} \text { sesamin) for } \\
4 \text { weeks vs. placebo }\end{array}$ & $\begin{array}{l}\text { Reduced PCOOH during } \\
\text { ASX suppl. vs. control } \\
\text { during mental tasks }\end{array}$ & $\begin{array}{l}\text { Faster recovery from mental } \\
\text { fatigue also, carotenoid not } \\
\text { given alone }\end{array}$ & [34] \\
\hline Lipid peroxides in serum & $\begin{array}{c}\text { Carotenoid free diet for } 2 \\
\text { weeks, followed by } \\
\text { beta-CAR } \\
\text { administration }\end{array}$ & $\begin{array}{c}N=15 \text { healthy male } \\
\text { subjects }\end{array}$ & $\begin{array}{l}\text { After } 2 \text { weeks of } \\
\text { intervention: either } 7 \text { or } 120 \\
(n=8) \text { mg beta-CAR/d for } 4 \\
\text { weeks with same carotenoid- } \\
\text { free liquid diet }\end{array}$ & $\begin{array}{c}\text { After repletion with } \\
\text { beta-CAR, lipid peroxide } \\
\text { levels sign. decreased in } \\
\text { both groups, } r=-0.60, \\
r=-0.58\end{array}$ & $\begin{array}{l}\text { Beta-CAR did not lower } \\
\text { serum lipid peroxides, no } \\
\text { changes in neutrophil } \\
\text { superoxide production }\end{array}$ & [187] \\
\hline $\begin{array}{l}\text { Total hydroperoxides } \\
\text { (TH), FRAP * }\end{array}$ & $\begin{array}{c}\text { Randomized, } \\
\text { double-blind, } \\
\text { placebo-controlled, } \\
\text { single-centre study }\end{array}$ & $\begin{aligned} N= & 20 \text { term new-borns } \\
& (10 \text { controls, } 10 \\
& \text { supplemented })\end{aligned}$ & $\begin{array}{l}\text { LUT or placebo at } 12 \text { and } \\
36 \mathrm{~h} \text { after birth each } 0.28 \mathrm{mg}\end{array}$ & $\begin{array}{l}\text { No increase of TH in LUT } \\
\text { group but sign. increase in } \\
\text { control group; sign. FRAP } \\
\text { increase in group receiving } \\
\text { LUT vs. no change } \\
\text { in controls }\end{array}$ & $\begin{array}{l}\text { Large variabilities, partly } \\
\text { non-normal distribution, } \\
\text { small clinical changes }\end{array}$ & [192] \\
\hline MDA & $\begin{array}{c}\text { Effect of surgical weight } \\
\text { loss on changes in } \\
\text { beta-CAR and plasma } \\
\text { MDA }\end{array}$ & $\begin{array}{c}N=22 \text { morbidly obese } \\
\text { patients }\end{array}$ & Not determined & $\begin{array}{l}\text { MDA sign. decreased }(50 \%) \\
\text { after operation, no sign. } \\
\text { change in beta-CAR }\end{array}$ & No dietary intake studied & [130] \\
\hline $\begin{array}{l}\text { MDA, total antioxidant } \\
\text { capacity (ABTS) }\end{array}$ & $\begin{array}{c}6 \text { months clinical single } \\
\text { centre trial }\end{array}$ & $\begin{array}{l}N=24 \text { patients with } \\
\text { cystic fibrosis }\end{array}$ & $\begin{array}{l}1 \mathrm{mg} / \mathrm{kg} / \mathrm{d} \text { (max. } 50 \mathrm{mg} / \text { day) } \\
\text { for } 3 \text { months vs. placebo }\end{array}$ & $\begin{array}{l}\text { Initially raised plasma levels } \\
\text { of MDA fell to normal, ABTS } \\
\text { showed ns. increase with } \\
\text { high dose }\end{array}$ & $\begin{array}{l}\text { Further suppl. with } 10 \mathrm{mg} / \mathrm{d} \\
\text { beta-CAR did not maintain } \\
\text { low MDA levels }\end{array}$ & [172] \\
\hline
\end{tabular}


Table 4. Cont

\begin{tabular}{|c|c|c|c|c|c|c|}
\hline Marker Measured & Study Design & Subjects & Carotenoid Intake & Findings & Comment & Ref. \\
\hline $\begin{array}{c}\text { Cu-mediated LDL } \\
\text { stability, SOD, GPx, GSH }\end{array}$ & $\begin{array}{l}\text { Placebo-controlled } \\
\text { single-blinded study }\end{array}$ & $\begin{array}{c}N=175 \text { healthy male } \\
\text { volunteers }\end{array}$ & $\begin{array}{l}\text { Daily suppl. of beta-CAR (15 } \\
\text { mg), LUT (15 mg), LYC (15 } \\
\text { mg) and placebo for } 3 \\
\text { months }\end{array}$ & $\begin{array}{l}\text { No sign. effect on any antiox. } \\
\text { parameter }\end{array}$ & $\begin{array}{l}\text { Clearly no effect on this } \\
\text { healthy population }\end{array}$ & [189] \\
\hline $\begin{array}{l}\text { MDA (plasma), } \\
\text { Cu-induced ex-vivo } \\
\text { oxidation of LDL }\end{array}$ & $\begin{array}{l}\text { Intervention with } \\
\text { beta-CAR in subjects } \\
\text { with cystic fibrosis (CF) }\end{array}$ & $\begin{array}{c}\mathrm{n}=34 \mathrm{CF} \text { patients, } \\
\text { before/after } 3 \text { months of } \\
\text { beta-CAR suppl., and } 42 \\
\text { healthy controls }\end{array}$ & $\begin{array}{c}0.5 \mathrm{mg} / \mathrm{kg} \text { body weight } \\
\text { beta-CAR }\end{array}$ & $\begin{array}{l}\text { Sig. increase of lag-time after } \\
\text { suppl., sign. reduced MDA, } \\
\text { sig. increase of beta-CAR, } \\
\text { regression of }-0.40 \mu \mathrm{M} \\
\text { MDA } / \mu \mathrm{M} \text { beta-CAR }\end{array}$ & $\begin{array}{c}\text { Beta-carotene deficiency can } \\
\text { be reduced by beta-carotene } \\
\text { supple- } \\
\text { mentation }\end{array}$ & [171] \\
\hline $\begin{array}{l}\text { MDA, Cu-induced LDL } \\
\text { stability }\end{array}$ & Supple-mentation trial & $\begin{array}{c}N=20 \text { patients with } \\
\text { long-standing } \\
\text { non-insulin-dependent } \\
\text { diabetes mellitus }\end{array}$ & $\begin{array}{l}\text { Dunaliella bardawil-derived } \\
\text { beta-CAR was suppl. to } \\
\text { patients for } 3 \text { weeks, } 60 \mathrm{mg} / \mathrm{d}\end{array}$ & $\begin{array}{c}\text { Reduced MDA ( } 25 \%), \text { LDL } \\
\text { susceptibility increased by } \\
40 \% \text { with } 35 \% \text { shorter } \\
\text { lag time }\end{array}$ & $\begin{array}{l}\text { High dose, rich in 9-cis } \\
\text { beta-CAR }\end{array}$ & [173] \\
\hline MDA, TEAC & Intervention study & $\begin{array}{c}N=42 \text { healthy subjects } \\
\text { divided into } 4 \text { groups }\end{array}$ & $\begin{array}{l}5 \mathrm{mg}, 10 \mathrm{mg}, 20 \mathrm{mg} \text { or } 40 \mathrm{mg} \\
\text { beta-CAR/d for } 5 \text { weeks }\end{array}$ & $\begin{array}{l}\text { Uric acid in plasma sign. } \\
\text { decreased in all groups, } \\
\text { TEAC ns. decreased in all } \\
\text { groups, MDA unchanged } \\
\text { except for } 40 \text { mg beta-CAR } \\
\text { group }(-18 \%)\end{array}$ & $\begin{array}{l}\text { Small-scale study, changes } \\
\text { rather small as subjects } \\
\text { already healthy, no placebo } \\
\text { group }\end{array}$ & [186] \\
\hline $\begin{array}{l}\text { MDA, ABTS, CRP, SOD; } \\
\text { CAT, GPx, in plasma }\end{array}$ & $\begin{array}{l}\text { LUT supple-mentation, } \\
\text { randomized placebo } \\
\text { controlled }\end{array}$ & $\begin{array}{l}N=117 \text { healthy } \\
\text { non-smokers }\end{array}$ & $\begin{array}{l}10 \text { or } 20 \mathrm{mg} / \mathrm{d} \text { of LUT or } \\
\text { placebo for } 12 \text { weeks }\end{array}$ & $\begin{array}{l}\text { LUT and ABTS sign. } \\
\text { increased in both LUT } \\
\text { groups. Sign. MDA } \\
\text { reduction with } 20 \mathrm{mg} \text { LUT, } \\
\text { dose-dependent CRP } \\
\text { decrease, sign. CRP diff. } \\
\text { between } 20 \mathrm{mg} \text { LUT and } \\
\text { placebo, CRP sign. related to } \\
\text { change in plasma LUT } \\
(r=-0.44) \text { and ABTS for } \\
\text { both groups }\end{array}$ & $\begin{array}{l}\text { No sign. change in other } \\
\text { parameters measured, } \\
\text { perhaps as subjects were } \\
\text { healthy and well educated }\end{array}$ & [181] \\
\hline $\begin{array}{l}\text { LDL oxidizability, MDA, } \\
\text { hydroxyl-nonenals, } \\
\text { urinary F2-isoprostanes } \\
\text { and 8-OH-dG and } \\
\text { lymphocytes (comet } \\
\text { assay) }\end{array}$ & $\begin{array}{l}\text { Dose-response study } \\
\text { with LYC on healthy } \\
\text { subjects, double-blind, } \\
\text { randomized, placebo- } \\
\text { controlled }\end{array}$ & $\begin{array}{l}\text { Healthy adults }(N=77 \\
\text { age } \geq 40 \text { years) }\end{array}$ & $\begin{array}{l}\text { LYC-restricted diet for } 2 \\
\text { weeks, then randomized to } \\
\text { receive } 0,6.5,15 \text { or } 30 \mathrm{mg} \\
\text { LYC/d for } 8 \text { weeks }\end{array}$ & $\begin{array}{c}\text { Sign. decrease in DNA } \\
\text { damage by comet assay and } \\
\text { a sign. decrease in } 8 \text {-OH-dG } \\
\text { at } 8 \text { weeks vs. baseline with } \\
30 \mathrm{mg} \text { LYC/d }\end{array}$ & $\begin{array}{l}\text { Limited effects as subjects } \\
\text { were healthy, less than } 10 \% \\
\text { changes via comet assay, } \\
\text { approximately } 25 \% \\
\text { reduction of } 8-\mathrm{OH}-\mathrm{dG}\end{array}$ & [196] \\
\hline
\end{tabular}


Table 4. Cont

\begin{tabular}{|c|c|c|c|c|c|c|}
\hline Marker Measured & Study Design & Subjects & Carotenoid Intake & Findings & Comment & Ref. \\
\hline $\begin{array}{l}\text { FRAP, F2-isoprostane, } \\
\text { oxidised phospholipid } \\
\text { biomarker in serum } \\
\text { (POVPC) }\end{array}$ & $\begin{array}{c}\text { Intervention with } \\
\text { supplement in } \\
\text { Alzheimer's disease } \\
\text { (AD) subjects vs. healthy } \\
\text { controls }\end{array}$ & $\begin{array}{c}n=21 \text { AD patients vs. } \\
16 \text { healthy age-matched } \\
\text { controls }\end{array}$ & $\begin{array}{l}10 \mathrm{mg} \text { meso-ZEA, } 10 \mathrm{mg} \\
\text { LUT, } 2 \mathrm{mg} \text { ZEA for } 6 \text { months }\end{array}$ & $\begin{array}{l}\text { IsoP conc. not related to } \\
\text { disease or suppl. FRAP sign. } \\
\text { lower and POVPC sign. } \\
\text { higher in AD than healthy } \\
\text { controls, but not changed by } \\
\text { carotenoids }\end{array}$ & na & [178] \\
\hline CRP & $\begin{array}{l}\text { Randomized controlled } \\
\text { multi-centre trial }\end{array}$ & $\begin{array}{c}N=183 \text { infants }<33 \\
\text { weeks gestational age }\end{array}$ & $\begin{array}{l}210 \mu \mathrm{g} / \mathrm{L} \text { in formula, about } \\
\text { equal parts beta-CAR, LUT, } \\
\mathrm{LYC} \text {, up to until } 40 \text { weeks } \\
\text { post-menstrual age }\end{array}$ & $\begin{array}{c}\text { Suppl. infants had lower } \\
\text { plasma CRP, } 0.2 \mathrm{vs} \text {. } \\
0.4 \mu \mathrm{g} / \mathrm{mL}\end{array}$ & $\begin{array}{l}\text { Infants on human milk had } \\
\text { similar CRP values than } \\
\text { those in LUT group }\end{array}$ & [193] \\
\hline $\begin{array}{l}\text { MDA, SOD, GPx, GR, } \\
\text { GSH, CAT }\end{array}$ & $\begin{array}{l}\text { LYC suppl. } 10 \text { weeks in } \\
\text { subjects with ox. stress } \\
\text { after a } 2 \text { week washout } \\
\text { period }\end{array}$ & $\begin{array}{c}45 \text { patients age } 40-60 \text { y } \\
\text { and } 30 \text { age and } \\
\text { sex-matched healthy } \\
\text { controls (not suppl., just } \\
\text { baseline!) }\end{array}$ & $\begin{array}{c}\text { Group } 1(n=15) \text { suppl. with } \\
15 \mathrm{mg} \text { LYC capsule, group } 2 \\
(n=15) 200 \mathrm{~g} \text { tomato } \\
\text { products containing } 15 \mathrm{mg} \\
\text { LYC, group } 3(n=15) \\
\text { placebo }\end{array}$ & $\begin{array}{l}\text { Patients: decreased lipid } \\
\text { peroxidation and enhanced } \\
\text { OS (all other markers) after } \\
\text { various forms of LYC suppl. }\end{array}$ & $\begin{array}{l}\text { Incomplete statistics, hard to } \\
\text { evaluate results, both } \\
\text { supplements and LYC rich } \\
\text { foods appear equally } \\
\text { effective, slight edge for } \\
\text { supplements }\end{array}$ & [181] \\
\hline $\begin{array}{c}\text { plasma IL-6, } \\
\text { monocyte-chemoattractant } \\
\text { protein (MCP-19, serum } \\
\text { apoE } \\
\end{array}$ & $\begin{array}{c}\text { Randomized } \\
\text { placebo-controlled trial }\end{array}$ & $\begin{array}{l}\text { Early atherosclerosis } \\
\text { patients }(N=65)\end{array}$ & $\begin{array}{l}20 \mathrm{mg} \text { LUT/d, } 3 \text { months vs. } \\
\text { placebo }\end{array}$ & $\begin{array}{l}\text { Reduced IL-6, but ns. } \\
\text { compared to control group, } \\
\text { reduced MCP-19, reduced } \\
\text { apoE }\end{array}$ & $\begin{array}{l}\text { No other inflammation } \\
\text { parameters investigated }\end{array}$ & [212] \\
\hline \multicolumn{7}{|c|}{ Food Items } \\
\hline $\begin{array}{c}\text { Phospholipid } \\
\text { hydroperoxides } \\
\text { (PLOOH) in } \\
\text { erythrocytes and plasma }\end{array}$ & $\begin{array}{c}\text { randomized, } \\
\text { double-blind } \\
\text { placebo-controlled with } \\
\text { chlorella algae }\end{array}$ & $\begin{array}{c}n=12 \text { normal senior } \\
\text { subjects, } n=6 / \text { group }\end{array}$ & $\begin{array}{c}2 \text { months chlorella Suppl. } \\
(8 \mathrm{~g} \text { chlorella/d; with } 22.9 \mathrm{mg} \\
\text { LUT/d }\end{array}$ & $\begin{array}{l}\text { Reduced PLOOH in suppl. } \\
\text { subject, but also in control } \\
\text { group, thus no sign. } \\
\text { difference between these }\end{array}$ & $\begin{array}{l}\text { Subjects were healthy, } \\
\text { underpowered study }\end{array}$ & [194] \\
\hline $\begin{array}{c}\text { Cu-induced LDL } \\
\text { oxidation ex vivo, SOD, } \\
\text { GPx, GSH, }\end{array}$ & $\begin{array}{l}\text { Intervention study with } \\
\text { fruits and vegetables for } \\
2 \text { weeks }\end{array}$ & $\begin{array}{l}\text { Smokers }(n=11) \text { and } \\
\text { age and gender-matched } \\
\text { non-smokers }(n=11)\end{array}$ & $30 \mathrm{mg} / \mathrm{d}$ via diet & $\begin{array}{l}\text { Carotenoids increased in } \\
\text { smokers } 23 \% \text { and } 11 \% \text { in } \\
\text { non-smokers, LDL resistance } \\
\text { to ox. increased by } 14 \% \text { in } \\
\text { smokers and } 28 \% \text { in } \\
\text { non-smokers }\end{array}$ & $\begin{array}{l}\text { Very small-scale study, } \\
\text { short-term, no sig. effect on } \\
\text { other antiox. markers }\end{array}$ & [177] \\
\hline $\begin{array}{l}\text { DNA strand breaks, ox. } \\
\text { DNA damage, plasma } \\
\text { MDA and } \\
\text { F2-isoprostanes, TEAC }\end{array}$ & $\begin{array}{c}\text { Randomized controlled } \\
\text { trial }\end{array}$ & $\begin{array}{l}N=64 \text { non-smoking } \\
\text { healthy male subjects }\end{array}$ & $\begin{array}{c}\text { Either low }(2 \text { servings/d), } \\
\text { medium }(5 \text { servings/d), or } \\
\text { high }(8 \text { servings/d) intake of } \\
\text { VF for another } 4 \text { wks. }\end{array}$ & $\begin{array}{l}\text { No changes in observed } \\
\text { parameters }\end{array}$ & $\begin{array}{l}\text { Already healthy subjects, } \\
\text { little changes }\end{array}$ & [197] \\
\hline $\begin{array}{l}\text { MDA, SOD, GPx, GR, } \\
\text { GSH }\end{array}$ & Intervention study & $\begin{array}{l}\text { hypertensive subjects } \\
\qquad(n=40)\end{array}$ & $\begin{array}{c}60 \mathrm{~d} \text { of tomato } \\
\text { supple-mentation, } 200 \mathrm{~g} \text { ripe } \\
\text { tomatoes/d }\end{array}$ & $\begin{array}{l}\text { Sign. reduction in MDA, } \\
\text { sign. increases in other } \\
\text { parameters }\end{array}$ & $\begin{array}{l}\text { No intake and plasma levels } \\
\text { of lycopene determined }\end{array}$ & [182] \\
\hline
\end{tabular}


Table 4. Cont.

\begin{tabular}{|c|c|c|c|c|c|c|}
\hline Marker Measured & Study Design & Subjects & Carotenoid Intake & Findings & Comment & Ref. \\
\hline $\begin{array}{l}\text { MDA, SOD, CAT, GPx, } \\
\text { protein thiols }\end{array}$ & $\begin{array}{c}\text { Dietary intervention } \\
\text { with diet low in LYC for } \\
1 \text { month }\end{array}$ & $\begin{array}{c}N=23 \text { healthy } \\
\text { post-menopausal } \\
\text { women }\end{array}$ & $\begin{array}{l}\text { Reduction from } 3.50 \mathrm{mg} / \mathrm{d} \text { to } \\
0.13 \mathrm{mg} / \mathrm{d}\end{array}$ & $\begin{array}{l}\text { Sig. decreased serum LYC } \\
\text { (1170 to } 495 \mathrm{nM} \text { ), LUT/ZEA, } \\
\text { alpha-\& beta-CAR. GPx, } \\
\text { lipid and protein ox. } \\
\text { increased (ns.), while CAT \& } \\
\text { SOD sign. decreased }\end{array}$ & $\begin{array}{l}\text { General reduction of fruits } \\
\text { and vegetables as major } \\
\text { confounder }\end{array}$ & [200] \\
\hline $\begin{array}{c}\text { Amyloid A } \\
\text { (apolipoprotein, marker } \\
\text { of systemic and } \\
\text { HDL-associated } \\
\text { inflammation) }\end{array}$ & $\begin{array}{l}\text { Randomized, controlled } \\
\text { intervention trial }\end{array}$ & $\begin{array}{c}\text { Middle-aged, } \\
\text { overweight adults, } n= \\
54\end{array}$ & $\begin{array}{l}\text { LYC-rich diet }(224-350 \mathrm{mg}) \\
\text { or supplements }(70 \mathrm{mg} / \mathrm{wk}) \text {, } \\
\text { for } 12 \mathrm{wks}\end{array}$ & $\begin{array}{c}\text { Reduced ( } 30 \%) \\
\text { serum-amyloid A for LYC } \\
\text { supplement group only }\end{array}$ & $\begin{array}{l}\text { No change in lycopene rich } \\
\text { diet without supplements }\end{array}$ & [213] \\
\hline $\begin{array}{l}\text { MDA (erythrocytes), } \\
\text { F2-isoprostanes (urine) }\end{array}$ & $\begin{array}{l}\text { Intervention study with } \\
\text { red palm oil (RPO) or } \\
\text { vitamin E }\end{array}$ & $\begin{array}{c}N=60 \text { patients (mean } \\
\text { age } 62 \mathrm{y} \text {, range } 54-75 \text { ) } \\
\text { with child } \mathrm{A} / \mathrm{B} \text {, genotype } \\
1 \text { hepatitis } \mathrm{C} \\
\text { virus-related cirrhosis }\end{array}$ & $\begin{array}{l}\text { Not determined, } 15 \mathrm{~g} \text { RPO } \\
\text { for } 8 \text { weeks }\end{array}$ & $\begin{array}{l}\text { Both treatments sign. } \\
\text { decreased erythrocyte MDA } \\
\text { and isoprostane output, } \\
\text { carotenoid treatment } \\
\text { stronger, by } \sim 30 \%\end{array}$ & $\begin{array}{l}\text { RPO also sign. affected } \\
\text { macrophage-colony } \\
\text { stimulating factor and } \\
\text { monocyte tissue factor }\end{array}$ & [180] \\
\hline MDA & $\begin{array}{l}\text { Single-blind, } \\
\text { placebo-controlled trial }\end{array}$ & $\begin{array}{l}N=31 \text { subjects with } \\
\text { grade- } 1 \text { hyper-tension }\end{array}$ & $\begin{array}{l}\text { 8-week treatment period } \\
\text { with tomato extract, } 250 \mathrm{mg} \\
(15 \mathrm{mg} \mathrm{LYC} / \mathrm{d})\end{array}$ & $\begin{array}{l}\text { MDA decreased from } 4.58 \text { to } \\
3.81 \mathrm{nmol} / \mathrm{mg}\end{array}$ & $\begin{array}{c}\text { Marginal changes in MDA, } \\
\text { but } 10 \mathrm{~mm} \text { Hg reduction in } \\
\text { systolic BP }\end{array}$ & [199] \\
\hline MDA, GSH & $\begin{array}{c}\text { Randomized controlled } \\
\text { trial }\end{array}$ & $\begin{array}{l}N=41 \text { healthy } \\
\text { post-meno-pausal } \\
\text { women, } 6 \text { months }\end{array}$ & $\begin{array}{c}\text { Either hormone replacement } \\
\text { therapy }(\mathrm{HRT}, n=21) \text { or } \\
\text { LycoRed }(n=20) \text { containing } \\
4 \mathrm{mg} \mathrm{LYC} / \mathrm{d}\end{array}$ & $\begin{array}{l}\text { MDA sign. decreased by } \\
16.3 \% \text { and } 13.3 \%, \text { GSH } \\
\text { increased sign. by } 5.9 \% \text { and } \\
12.5 \% \text { in HRT and LycoRed } \\
\text { groups, resp. }\end{array}$ & $\begin{array}{c}\text { Limited effects, likely due to } \\
\text { the generally healthy } \\
\text { subjects }\end{array}$ & [198] \\
\hline MDA, 8-OH-dG & $\begin{array}{l}\text { Double-blind, } \\
\text { randomized, } \\
\text { placebo-controlled trial }\end{array}$ & $\begin{array}{l}105 \text { African men, } \\
\text { veterans, recommended } \\
\text { for prostate biopsy }\end{array}$ & $\begin{array}{c}\text { Tomato oleorosin with } 30 \\
\text { mg/d LYC vs. placebo }\end{array}$ & $\begin{array}{l}\text { No sign. changes in MDA in } \\
\text { plasma. Tissue 8-OH-dG } \\
\text { lower but ns. vs. controls }\end{array}$ & $\begin{array}{c}\text { Too large variability in tissue } \\
\text { 8-OH-dG }\end{array}$ & [185] \\
\hline $\begin{array}{l}\text { Lymphocyte 8-OH-DhG, } \\
\text { urinary urinary } \\
\text { F2-isopostanes }\end{array}$ & $\begin{array}{l}\text { Dietary intervention } \\
\text { with diets rich in } \\
\text { botanicals, } 8-10 \text { servings } \\
\text { of VF/d in low (LB) or } \\
\text { high (HB) botanical } \\
\text { variety study, for } 14 \mathrm{~d}\end{array}$ & $\begin{array}{c}n=2 \times 53 \text { healthy } \\
\text { women }\end{array}$ &  & $\begin{array}{l}\text { Sign. decrease for both diets } \\
\text { for } 8 \text {-OH-dG, }-0.03 \text { and } \\
-0.81 \text {; and } 8 \text {-iso-PGF2a: } \\
-0.05 \mu \mathrm{mol},-0.13\end{array}$ & $\begin{array}{l}\text { LB slightly less effective than } \\
\text { HB, both diets of same } \\
\text { macronutrient comp., more } \\
\text { diverse phyto- chemicals in } \\
\text { smaller amounts superior? }\end{array}$ & [205] \\
\hline
\end{tabular}


Table 4. Cont.

\begin{tabular}{|c|c|c|c|c|c|c|}
\hline Marker Measured & Study Design & Subjects & Carotenoid Intake & Findings & Comment & Ref. \\
\hline $\begin{array}{l}\text { 8-OH-dG, lipid } \\
\text { peroxides }\end{array}$ & $\begin{array}{c}\text { double-blinded, } \\
\text { randomized, } \\
\text { placebo-controlled study, } \\
28 \mathrm{~d}\end{array}$ & $\begin{array}{l}\text { Healthy Japanese adults, } \\
\qquad N=60\end{array}$ & $\begin{array}{l}\text { Capsules with juice powder } \\
\text { conc. from apple, orange, } \\
\text { pineapple, papaya, } \\
\text { cranberry, acerola cherry, } \\
\text { peach, carrot, parsley, } \\
\text { beetroot, broccoli, cabbage, } \\
\text { spinach, tomato, kale, barley } \\
\text { \& oat bran, with ca. } 234 \mathrm{mg} \\
\text { vit. C, } 32 \mathrm{mg} \text { vit. E, } 7.5 \mathrm{mg} \\
\text { beta- CAR equivalents and } \\
160 \mathrm{mg} \text { bioflavonoids/d. }\end{array}$ & $\begin{array}{l}\text { Measures of ox. stress } \\
\text { decreased with serum lipid } \\
\text { peroxides declining }-10.5 \% \\
\text { and urine } 8 \text {-OH-dG } \\
\text { decreased }-21.1 \%\end{array}$ & $\begin{array}{l}\text { Similar improvements in } \\
\text { smokers vs. non-smokers }\end{array}$ & [188] \\
\hline $\begin{array}{l}\text { Urinary F2-isoprostanes, } \\
\text { 8-OH-dG in urine and } \\
\text { lymphocytes }\end{array}$ & $\begin{array}{l}\text { Dietary intervention for } \\
2 \text { weeks, receiving } 12 \\
\text { portions fruits/ } \\
\text { vegetables per day }\end{array}$ & $\begin{array}{l}N=37 \text { healthy women } \\
\text { at risk for breast cancer }\end{array}$ & Not determined & $\begin{array}{c}\text { Sign. corr. between all } \\
\text { markers and plasma } \\
\text { carotenoids, sign. corr. } \\
\text { between change in plasma } \\
\text { xanthophylls and } \\
\text { lymphocyte } 8 \text {-OH-dG, } \\
r=-0.45\end{array}$ & $\begin{array}{l}\text { No other sign. correlations } \\
\text { observed during } 2 \text { week } \\
\text { study, too short intervention }\end{array}$ & [204] \\
\hline $\begin{array}{c}\text { TNF- } \alpha \text {, basal } \\
\text { lymphocyte DNA } \\
\text { damage (comet assay), } \\
\text { F2-isoprostanes (urine) }\end{array}$ & $\begin{array}{l}\text { Placebo-controlled } \\
\text { crossover trial }\end{array}$ & $N=26$ healthy subjects & $\begin{array}{c}\text { Lyc-o-Mato drink: } 5.7 \mathrm{mg} \\
\text { Lyc, } 3.7 \mathrm{mg} \text { PHY, } 2.7 \mathrm{mg} \text { PHF, } \\
1 \mathrm{mg} \text { beta-CAR, } 1.8 \mathrm{mg} \\
\alpha-\mathrm{TOC} \text { for } 26 \mathrm{~d}\end{array}$ & $\begin{array}{l}\text { TNF- } \alpha \text { secretion decreased } \\
34 \% \text { compared to control }\end{array}$ & $\begin{array}{l}\text { No effect on other } \\
\text { parameters }\end{array}$ & [214] \\
\hline CRP & $\begin{array}{l}\text { Lycopene: Randomized } \\
\text { controlled trial }\end{array}$ & $\begin{array}{c}n=22, \text { men and women } \\
\text { in patients with heart } \\
\text { failure vs. control }(n= \\
18)\end{array}$ & $\begin{array}{c}30 \mathrm{mg} / \mathrm{d} \text { for } 30 \mathrm{~d} \text { within } \mathrm{V} 8 \\
\text { tomato juice }\end{array}$ & $\begin{array}{l}\text { CRP } \downarrow(25 \%) \text { in women (not } \\
\text { men) } \downarrow\end{array}$ & Gender-specific effects & [215] \\
\hline $\begin{array}{l}\text { IL-2, IL-4, TNF- } \alpha \text { of } \\
\text { cultured PBMCs }\end{array}$ & $\begin{array}{l}\text { Randomized controlled } \\
\text { trial }\end{array}$ & $N=55$ elderly & $\begin{array}{c}330 \mathrm{~mL} / \mathrm{d} \text { tomato juice }(47.1 \\
\mathrm{mg} / \mathrm{d} \text { LYC) for } 8 \text { weeks }\end{array}$ & $\begin{array}{l}\text { No effect compared to } \\
\text { control group }\end{array}$ & & [216] \\
\hline
\end{tabular}

* FRAP: Ferric-reducing antioxidant power test; ${ }^{* *}$ method not further described; PBMCs: peripheral blood mononuclear cells; PHY: phytoene, PHF: phytofluene; POVPC:

1-palmitoyl-2-(5'-oxo-valeroyl)-sn-glycero-3-phosphocholine; TEAC: trolox equivalent antioxidant capacity; VF: vegetables and fruits. For additional abbreviations, see Table 3. 


\section{Summary and Conclusions}

A number of chronic diseases are characterized by low-grade chronic inflammation, which is also related to elevated oxidative stress, with each of the two potentially aggravating one another. Though many markers of oxidative stress have been proposed, no single one is likely to convey a complete picture of oxidative stress homeostasis, due to the many different body compartments, mechanisms and number of biomolecules involved. Thus, it is advisable to measure several such markers in any human study. The EFSA recommends at present F2-isoprostanes, direct measurements of lipid peroxides and oxLDL. While admitting that additional markers could have some benefits, the EFSA is not acknowledging other frequently measured markers, such as those related to antioxidant capacity (FRAP, ORAC, etc.) or DNA degradation via, for example, 8-OH-dG [72] on its own.

Nevertheless, many of these markers, recommended or not, have been employed in several dozens of small- to large-scale studies, showing a clear relation of carotenoid intake and blood plasma/serum concentrations to chronic diseases and markers of oxidative stress, even suggesting plasma levels of at least $1 \mu \mathrm{M}$ of total carotenoids [21]. Especially for subjects with chronic diseases, higher levels of oxidative stress and reduced antioxidant capacity in body tissues have been reported, and these tend to inversely correlate with total and major individual carotenoids. However, care should be taken to propose a causal relationship, as carotenoids are a very good marker for a general intake of fruits and vegetables, which are also rich in dietary fibre, polyphenols and other secondary plant compounds such as lignans and glucosinolates, as well as certain vitamins and minerals.

Mechanistically plausible pathways include, in addition to direct quenching abilities of carotenoids, as outlined above, their influence on transcription factors and nuclear factors, especially Nrf-2 and RXR/PPARs, though to the author's knowledge, no studies have investigated changes in these markers upon supplementation in humans until now. The involvement of Nrf-2 in carotenoid-reduced oxidative stress has been shown in in vitro experiments and animal studies as reviewed previously [18] and RAR/RXR as well as RXR/PPARs in the differentiation of adicpocytes [90]. Especially Nrf-2 and PPAR $\gamma$ have been emphasized to be activated by carotenoids [217,218], with Nrf-2 binding to ARE receptors in the nucleus together with Maf (muscular aponeurotic fibrosarcoma), and PPAR $\gamma$ together with RXR, influencing the downstream expression of Nrf-2, CAT and SOD, among others.

The intervention studies conducted show mixed results, with generally no or small positive changes in markers of oxidative stress in healthy subjects. Obviously, oxidative stress homeostasis, when following a healthy mixed diet, does not require more carotenoids for further improvements. This may be different in subjects with chronic diseases, and here supplementation with both supplements and food items rich in carotenoids such as tomatoes have shown beneficial effects on markers of oxidative stress. Again, one should be careful to deduce that such a reduction of oxidative stress markers will automatically reduce mortality or morbidity related to the underlying disease. This has so far not clearly been shown in human trials, despite being plausible. The increased lung cancer rates in some supplementation trials demand prudency with high-dosed individual supplements, though negative effects appear limited to high doses of beta-carotene in smokers and asbestos workers regarding lung and stomach cancer. Clearly, no adverse effects were encountered in short-term supplementation trials and trials with elevated fruit and vegetable consumption, which thus, remains the most recommended approach to ensure optimal ROS homeostasis, likely related to decreased chronic diseases.

Funding: No funding was received for this article.

Acknowledgments: The author would like to acknowledge networking support by the COST Actions FA 1403 (POSITIVE) and CA 15136 (EUROCAROTEN).

Conflicts of Interest: The author reports no conflict of interest.

\section{References}

1. Steiger, S.; Perez-Fons, L.; Fraser, P.D.; Sandmann, G. Biosynthesis of a novel C30 carotenoid in bacillus firmus isolates. J. Appl. MicroBiol. 2012, 113, 888-895. [CrossRef] 
2. Yabuzaki, J. Carotenoids database: Structures, chemical fingerprints and distribution among organisms. Database 2017, 2017. [CrossRef] [PubMed]

3. Kim, S.H.; Kim, M.S.; Lee, B.Y.; Lee, P.C. Generation of structurally novel short carotenoids and study of their biological activity. Sci. Rep. 2016, 6, 21987. [CrossRef]

4. Squillaci, G.; Parrella, R.; Carbone, V.; Minasi, P.; La Cara, F.; Morana, A. Carotenoids from the extreme halophilic archaeon Haloterrigena turkmenica: Identification and antioxidant activity. Extremophiles 2017, 21, 933-945. [CrossRef] [PubMed]

5. Chen, C.W.; Hsu, S.H.; Lin, M.T.; Hsu, Y.H. Mass production of C50 carotenoids by haloferax mediterranei in using extruded rice bran and starch under optimal conductivity of brined medium. BioProc.ess Biosyst. Eng. 2015, 38, 2361-2367. [CrossRef] [PubMed]

6. Heider, S.A.E.; Peters-Wendisch, P.; Wendisch, V.F.; Beekwilder, J.; Brautaset, T. Metabolic engineering for the microbial production of carotenoids and related products with a focus on the rare C50 carotenoids. Appl. MicroBiol. Biotechnol. 2014, 98, 4355-4368. [CrossRef]

7. Hou, J.; Cui, H.L. In vitro antioxidant, antihemolytic, and anticancer activity of the carotenoids from halophilic archaea. Curr. MicroBiol. 2018, 75, 266-271. [CrossRef] [PubMed]

8. Böhm, V.; Borel, P.; Corte-Real, J. From carotenoid intake to carotenoid/metabolite blood and tissue concentrations-Implications for dietary intake recommendations. Nutr. Rev. 2018. under review.

9. Manach, C.; Scalbert, A.; Morand, C.; Rémésy, R.; Jiménez, L. Polyphenols: Food sources and bioavailability. Am. J. Clin. Nutr. 2004, 79, 727-747. [CrossRef]

10. Kancheva, V.D.; Kasaikina, O.T. Bio-antioxidants-A chemical base of their antioxidant activity and beneficial effect on human health. Curr. Med. Chem. 2013, 20, 4784-4805. [CrossRef]

11. Erdman, J.W., Jr.; Ford, N.A.; Lindshield, B.L. Are the health attributes of lycopene related to its antioxidant function? Arch. BioChem. Biophys. 2009, 483, 229-235. [CrossRef] [PubMed]

12. Briviba, K.; Schnabele, K.; Rechkemmer, G.; Bub, A. Supplementation of a diet low in carotenoids with tomato or carrot juice does not affect lipid peroxidation in plasma and feces of healthy men. J. Nutr. 2004, 134, 1081-1083. [CrossRef] [PubMed]

13. Rühl, R. Effects of dietary retinoids and carotenoids on immune development. Proc. Nutr. Soc. 2007, 66, 458-469. [CrossRef] [PubMed]

14. Bonet, M.L.; Canas, J.A.; Ribot, J.; Palou, A. Carotenoids in adipose tissue biology and obesity. Subcell. BioChem. 2016, 79, 377-414. [PubMed]

15. FAO. Enrichment of dried skim milk with special reference to vitamin A. Food Nutr. 1977, 3, $2-7$.

16. Linnewiel, K.; Ernst, H.; Caris-Veyrat, C.; Ben-Dor, A.; Kampf, A.; Salman, H.; Danilenko, M.; Levy, J.; Sharoni, Y. Structure activity relationship of carotenoid derivatives in activation of the electrophile/antioxidant response element transcription system. Free Radic. Biol. Med. 2009, 47, 659-667. [CrossRef]

17. Linnewiel-Hermoni, K.; Motro, Y.; Miller, Y.; Levy, J.; Sharoni, Y. Carotenoid derivatives inhibit nuclear factor kappa B activity in bone and cancer cells by targeting key thiol groups. Free Radic. Biol. Med. 2014, 75, 105-120. [CrossRef]

18. Kaulmann, A.; Bohn, T. Carotenoids, inflammation, and oxidative stress-Implications of cellular signaling pathways and relation to chronic disease prevention. Nutr. Res. 2014, 34, 907-929. [CrossRef]

19. Buijsse, B.; Feskens, E.J.; Schlettwein-Gsell, D.; Ferry, M.; Kok, F.J.; Kromhout, D.; de Groot, L.C. Plasma carotene and alpha-tocopherol in relation to 10-y all-cause and cause-specific mortality in European elderly: The survey in Europe on nutrition and the elderly, a concerted action (SENECA). Am. J. Clin. Nutr. 2005, 82, 879-886.

20. Beydoun, M.A.; Chen, X.; Jha, K.; Beydoun, H.A.; Zonderman, A.B.; Canas, J.A. Carotenoids, vitamin A, and their association with the metabolic syndrome: A systematic review and meta-analysis. Nutr. Rev. 2019, 77, 32-45. [CrossRef]

21. Donaldson, M.S. A carotenoid health index based on plasma carotenoids and health outcomes. Nutrients 2011, 3, 1003-1022. [CrossRef] [PubMed]

22. CDC. National Report on Biochemical Indicators of Diet and Nutrition in the U.S. Population 1999-2002; CDC: Atlanta, GA, USA, 2008. 
23. Albanes, D.; Heinonen, O.P.; Taylor, P.R.; Virtamo, J.; Edwards, B.K.; Rautalahti, M.; Hartman, A.M.; Palmgren, J.; Freedman, L.S.; Haapakoski, J.; et al. Alpha-Tocopherol and beta-carotene supplements and lung cancer incidence in the alpha-tocopherol, beta-carotene cancer prevention study: Effects of base-line characteristics and study compliance. J. Natl. Cancer Inst. 1996, 88, 1560-1570. [CrossRef] [PubMed]

24. Omenn, G.S.; Goodman, G.E.; Thornquist, M.D.; Balmes, J.; Cullen, M.R.; Glass, A.; Keogh, J.P.; Meyskens, F.L., Jr.; Valanis, B.; Williams, J.H., Jr.; et al. Effects of a combination of beta carotene and vitamin A on lung cancer and cardiovascular disease. N. Engl. J. Med. 1996, 334, 1150-1155. [CrossRef] [PubMed]

25. Cullen, M.R.; Barnett, M.J.; Balmes, J.R.; Cartmel, B.; Redlich, C.A.; Brodkin, C.A.; Barnhart, S.; Rosenstock, L.; Goodman, G.E.; Hammar, S.P.; et al. Predictors of lung cancer among asbestos-exposed men in the \{beta\}-carotene and retinol efficacy trial. Am. J. Epidemiol. 2005, 161, 260-270. [CrossRef] [PubMed]

26. Albanes, D.; Virtamo, J.; Taylor, P.R.; Rautalahti, M.; Pietinen, P.; Heinonen, O.P. Effects of supplemental beta-carotene, cigarette smoking, and alcohol consumption on serum carotenoids in the alpha-tocopherol, beta-carotene cancer prevention study. Am. J. Clin. Nutr. 1997, 66, 366-372. [CrossRef] [PubMed]

27. Bohn, T. Carotenoids, chronic disease prevention and dietary recommendations. Int. J. Vitam. Nutr. Res. 2018, 1, 10. [CrossRef] [PubMed]

28. Forrester, S.J.; Kikuchi, D.S.; Hernandes, M.S.; Xu, Q.; Griendling, K.K. Reactive oxygen species in metabolic and inflammatory signaling. Circ. Res. 2018, 122, 877-902. [CrossRef]

29. USDA (2015) National Nutrient Database for Standard Reference Release 28. Available online: http: //ndb.nal.usda.gov/ndb/foods/show (accessed on 5 November 2015).

30. Paetau, I.; Khachik, F.; Brown, E.D.; Beecher, G.R.; Kramer, T.R.; Chittams, J.; Clevidence, B.A. Chronic ingestion of lycopene-rich tomato juice or lycopene supplements significantly increases plasma concentrations of lycopene and related tomato carotenoids in humans. Am. J. Clin. Nutr. 1998, 68, 1187-1195. [CrossRef]

31. Biehler, E.; Alkerwi, A.; Hoffmann, L.; Krause, E.; Guillaume, M.; Lair, M.L.; Bohn, T. Contribution of violaxanthin, neoxanthin, phytoene and phytofluene to total carotenoid intake: Assessment in luxembourg. J. Food Compos. Anal. 2012, 25, 56-65. [CrossRef]

32. Zhou, C.H.; Xu, C.J.; Sun, C.D.; Li, X.; Chen, K.S. Carotenoids in white-and red-fleshed loquat fruits. J. Agric. Food Chem. 2007, 55, 7822-7830. [CrossRef]

33. Ambati, R.R.; Phang, S.M.; Ravi, S.; Aswathanarayana, R.G. Astaxanthin: Sources, extraction, stability, biological activities and its commercial applications-A review. Mar. Drugs 2014, 12, 128-152. [CrossRef] [PubMed]

34. Imai, A.; Oda, Y.; Ito, N.; Seki, S.; Nakagawa, K.; Miyazawa, T.; Ueda, F. Effects of dietary supplementation of astaxanthin and sesamin on daily fatigue: A randomized, double-blind, placebo-controlled, two-way crossover study. Nutrients 2018, 10, 281. [CrossRef] [PubMed]

35. Timmermans, B. Fucoxanthin: A Promising Bioproduct to Be Derived from Algae? Rijksuniversiteit: Groningen, The Netherlands, 2016.

36. Brizio, P.; Benedetto, A.; Righetti, M.; Prearo, M.; Gasco, L.; Squadrone, S.; Abete, M.C. Astaxanthin and canthaxanthin (xanthophyll) as supplements in rainbow trout diet: In vivo assessment of residual levels and contributions to human health. J. Agric. Food Chem. 2013, 61, 10954-10959. [CrossRef] [PubMed]

37. Esatbeyoglu, T.; Rimbach, G. Canthaxanthin: From molecule to function. Mol. Nutr. Food Res. 2017, 61, 1600469. [CrossRef] [PubMed]

38. EFSA. Scientific opinion on the re-evaluation of canthaxanthin (E $161 \mathrm{~g}$ ) as a food additive. EFSA J. 2010, 8 , 1852. [CrossRef]

39. Sy, C.; Gleize, B.; Dangles, O.; Landrier, J.F.; Veyrat, C.C.; Borel, P. Effects of physicochemical properties of carotenoids on their bioaccessibility, intestinal cell uptake, and blood and tissue concentrations. Mol. Nutr. Food Res. 2012, 56, 1385-1397. [CrossRef] [PubMed]

40. Burton, G.W.; Ingold, K.U. Beta-Carotene: An unusual type of lipid antioxidant. Science 1984, 224, 569-573. [CrossRef]

41. Gruszecki, W.I.; Strzalka, K. Carotenoids as modulators of lipid membrane physical properties. Biochim. Biophys. Acta 2005, 1740, 108-115. [CrossRef]

42. Krinsky, N.I.; Johnson, E.J. Carotenoid actions and their relation to health and disease. Mol. Asp. Med. 2005, 26, 459-516. [CrossRef] 
43. El-Agamey, A.; Lowe, G.M.; McGarvey, D.J.; Mortensen, A.; Phillip, D.M.; Truscott, T.G.; Young, A.J. Carotenoid radical chemistry and antioxidant/pro-oxidant properties. Arch. BioChem. Biophys. 2004, 430, 37-48. [CrossRef]

44. Schaich, K.M.; Borg, D.C. Fenton reactions in lipid phases. Lipids 1988, 23, 570-579. [CrossRef] [PubMed]

45. Conn, P.F.; Lambert, C.; Land, E.J.; Schalch, W.; Truscott, T.G. Carotene-oxygen radical interactions. Free Radic. Res. Commun. 1992, 16, 401-408. [CrossRef] [PubMed]

46. Chiste, R.C.; Freitas, M.; Mercadante, A.Z.; Fernandes, E. Carotenoids inhibit lipid peroxidation and hemoglobin oxidation, but not the depletion of glutathione induced by ROS in human erythrocytes. Life Sci. 2014, 99, 52-60. [CrossRef] [PubMed]

47. Ito, F.; Sono, Y.; Ito, T. Measurement and clinical significance of lipid peroxidation as a biomarker of oxidative stress: Oxidative stress in diabetes, atherosclerosis, and chronic inflammation. AntiOxid.ants 2019, 8, 72. [CrossRef] [PubMed]

48. Ayala, A.; Munoz, M.F.; Arguelles, S. Lipid peroxidation: Production, metabolism, and signaling mechanisms of malondialdehyde and 4-hydroxy-2-nonenal. Oxid. Med. Cell Longev. 2014, 2014, 360438. [CrossRef] [PubMed]

49. Sharma, R.A.; Gescher, A.; Plastaras, J.P.; Leuratti, C.; Singh, R.; Gallacher-Horley, B.; Offord, E.; Marnett, L.J.; Steward, W.P.; Plummer, S.M. Cyclooxygenase-2, malondialdehyde and pyrimidopurinone adducts of deoxyguanosine in human colon cells. Carcinogenesis 2001, 22, 1557-1560. [CrossRef]

50. Nam, T.G. Lipid peroxidation and its toxicological implications. Toxicol. Res. 2011, 27, 1-6. [CrossRef]

51. Spies-Martin, D.; Sommerburg, O.; Langhans, C.D.; Leichsenring, M. Measurement of 4-hydroxynonenal in small volume blood plasma samples: Modification of a gas chromatographic-mass spectrometric method for clinical settings. J. Chromatogr. B 2002, 774, 231-239. [CrossRef]

52. Il'yasova, D.; Scarbrough, P.; Spasojevic, I. Urinary biomarkers of oxidative status. Clin. Chim. Acta 2012, 413, 1446-1453. [CrossRef]

53. Kumar, A.; Dhillon, B.S.; Rao, D.N.; Menon, G.; Shankar, H.; Dhaliwal, L.K.; Leema, M.; Chandhiok, N.; Kumar, N.; Sehgal, R.; et al. Temporal trends of malondialdehyde in stored human plasma. Indian J. Clin. Biochem. 2012, 27, 405-409. [CrossRef]

54. Tsikas, D.; Suchy, M.T.; Niemann, J.; Tossios, P.; Schneider, Y.; Rothmann, S.; Gutzki, F.M.; Frölich, J.C.; Stichtenoth, D.O. Glutathione promotes prostaglandin H synthase (cyclooxygenase)-dependent formation of malondialdehyde and 15(S)-8-iso-prostaglandin F2alpha. FEBS Lett. 2012, 586, 3723-3730. [CrossRef] [PubMed]

55. Da Silva, M.S.; Bilodeau, J.F.; Julien, P.; Rudkowska, I. Dietary fats and F2-isoprostanes: A review of the clinical evidence. Crit. Rev. Food Sci. Nutr. 2017, 57, 3929-3941. [CrossRef] [PubMed]

56. Kaviarasan, S.; Muniandy, S.; Qvist, R.; Ismail, I.S. F(2)-isoprostanes as novel biomarkers for type 2 diabetes: A review. J. Clin. Biochem. Nutr. 2009, 45, 1-8. [CrossRef]

57. Kitano, S.; Hisatomi, H.; Hibi, N.; Kawano, K.; Harada, S. Improved method of plasma 8-Isoprostane measurement and association analyses with habitual drinking and smoking. World J. Gastroenterol. 2006, 12, 5846-5852. [CrossRef] [PubMed]

58. Chen, Y.; Junger, W.G. Measurement of oxidative burst in neutrophils. Methods Mol. Biol. 2012, 844, 115-124. [PubMed]

59. Slauch, J.M. How does the oxidative burst of macrophages kill bacteria? Still an open question. Mol. MicroBiol. 2011, 80, 580-583. [CrossRef] [PubMed]

60. Min, D.B.; Boff, J.M. Chemistry and reaction of singlet oxygen in foods. Compr. Rev. Food Sci. Food Saf. 2002, 1, 58-72. [CrossRef]

61. Ojima, F.; Sakamoto, H.; Ishiguro, Y.; Terao, J. Consumption of carotenoids in photosensitized oxidation of human plasma and plasma low-density lipoprotein. Free Radic. Biol. Med. 1993, 15, 377-384. [CrossRef]

62. Turrens, J.F. Mitochondrial formation of reactive oxygen species. J. Physiol. 2003, 552, 335-344. [CrossRef]

63. Valavanidis, A.; Vlachogianni, T.; Fiotakis, C. 8-hydroxy-2' -deoxyguanosine (8-OHdG): A critical biomarker of oxidative stress and carcinogenesis. J. Environ. Sci. Health Part C 2009, 27, 120-139. [CrossRef]

64. Cadet, J.; Douki, T.; Gasparutto, D.; Ravanat, J.L. Oxidative damage to DNA: Formation, measurement and biochemical features. Mutat. Res. 2003, 531, 5-23. [CrossRef] [PubMed] 
65. Poulsen, H.E.; Loft, S.; Prieme, H.; Vistisen, K.; Lykkesfeldt, J.; Nyyssonen, K.; Salonen, J.T. Oxidative DNA damage in vivo: Relationship to age, plasma antioxidants, drug metabolism, glutathione-S-transferase activity and urinary creatinine excretion. Free Radic. Res. 1998, 29, 565-571. [CrossRef]

66. Goulinet, S.; Chapman, M.J. Plasma LDL and HDL subspecies are heterogenous in particle content of tocopherols and oxygenated and hydrocarbon carotenoids: Relevance to oxidative resistance and atherogenesis. Arterioscler. Thromb. Vasc. Biol. 1997, 17, 786-796. [CrossRef] [PubMed]

67. Romanchik, J.E.; Morel, D.W.; Harrison, E.H. Distributions of carotenoids and alpha-tocopherol among lipoproteins do not change when human plasma is incubated in vitro. J. Nutr. 1995, 125, 2610-2617. [PubMed]

68. Gao, S.; Liu, J. Association between circulating oxidized low-density lipoprotein and atherosclerotic cardiovascular disease. Chr. Dis. Transl. Med. 2017, 3, 89-94. [CrossRef] [PubMed]

69. Itabe, H. Oxidized low-density lipoprotein as a biomarker of in vivo oxidative stress: From atherosclerosis to periodontitis. J. Clin. Biochem. Nutr. 2012, 51, 1-8. [CrossRef] [PubMed]

70. Itabe, H.; Ueda, M. Measurement of plasma oxidized low-density lipoprotein and its clinical implications. J. ATher.oscler. Thromb. 2007, 14, 1-11. [CrossRef] [PubMed]

71. Yin, H.; Xu, L.; Porter, N.A. Free radical lipid peroxidation: Mechanisms and analysis. Chem. Rev. 2011, 111, 5944-5972. [CrossRef]

72. EFSA. Guidance on the scientific requirements for health claims related to antioxidants, oxidative damage and cardiovascular health. EFSA J. 2018, 16, 5136.

73. Yamamoto, Y.; Kambayashi, Y.; Ueda, T. Assay of phospholipid hydroperoxides by chemiluminescence-based high-performance liquid chromatography. Methods Mol. Biol. 1998, 108, 63-70.

74. Granato, D.; Shahidi, F.; Wrolstad, R.; Kilmartin, P.; Melton, L.D.; Hidalgo, F.J.; Miyashita, K.; Camp, J.V.; Alasalvar, C.; Ismail, A.B. Antioxidant activity, total phenolics and flavonoids contents: Should we ban in vitro screening methods? Food Chem. 2018, 264, 471-475. [CrossRef] [PubMed]

75. Alam, M.N.; Bristi, N.J.; Rafiquzzaman, M. Review on in vivo and in vitro methods evaluation of antioxidant activity. Saudi Pharm. J. 2013, 21, 143-152. [CrossRef] [PubMed]

76. Garrett, A.R.; Murray, B.K.; Robison, R.A.; O'Neill, K.L. Measuring antioxidant capacity using the ORAC and TOSC assays. Methods Mol. Biol. 2010, 594, 251-262. [PubMed]

77. Gülçin, İ. (2015) Fe3+-Fe2+ Transformation Method: An Important Antioxidant Assay. In Advanced Protocols in Oxidative Stress III; Armstrong, D., Ed.; Springer: New York, NY, USA, 2015; pp. 233-246.

78. Olszowy, M.; Dawidowicz, A.L. Is it possible to use the DPPH and ABTS methods for reliable estimation of antioxidant power of colored compounds? Chem. Pap. 2018, 72, 393-400. [CrossRef]

79. Kedare, S.B.; Singh, R.P. Genesis and development of DPPH method of antioxidant assay. J. Food Sci. Technol. 2011, 48, 412-422. [CrossRef] [PubMed]

80. Prior, R.L.; Hoang, H.; Gu, L.; Wu, X.; Bacchiocca, M.; Howard, L.; Hampsch-Woodill, M.; Huang, D.; Ou, B.; Jacob, R. Assays for hydrophilic and lipophilic antioxidant capacity (oxygen radical absorbance capacity (ORAC(FL))) of plasma and other biological and food samples. J. Agric. Food Chem. 2003, 51, 3273-3279. [CrossRef]

81. Cano, A.; Alcaraz, O.; Acosta, M.; Arnao, M.B. On-line antioxidant activity determination: Comparison of hydrophilic and lipophilic antioxidant activity using the ABTS*+assay. Redox. Rep. 2002, 7, 103-109. [CrossRef]

82. Abramovic, H.; Grobin, B.; Poklar Ulrih, N.; Cigić, B. Relevance and standardization of in vitro antioxidant assays: ABTS, DPPH, and Folin-Ciocalteu. J. Chem. 2018, 2018, 9. [CrossRef]

83. Huang, Y.; Li, W.; Su, Z.Y.; Kong, A.N. The complexity of the Nrf2 pathway: Beyond the antioxidant response. J. Nutr. Biochem. 2015, 26, 1401-1413. [CrossRef]

84. Liu, T.; Zhang, L.; Joo, D.; Sun, S.C. NF-kappaB signaling in inflammation. Signal Transduct. Targ. Ther. 2017, 2, 17023. [CrossRef]

85. Margaritelis, N.V.; Veskoukis, A.S.; Paschalis, V.; Vrabas, I.S.; Dipla, K.; Zafeiridis, A.; Kyparos, A.; Nikolaidis, M.G. Blood reflects tissue oxidative stress: A systematic review. Biomarkers 2015, 20, 97-108. [CrossRef] [PubMed]

86. Fukai, T.; Ushio-Fukai, M. Superoxide dismutases: Role in redox signaling, vascular function, and diseases. AntiOxid. Redox. Signal 2011, 15, 1583-1606. [CrossRef]

87. McCord, J.M. Superoxide dismutase, lipid peroxidation, and bell-shaped dose response curves. Dose Response 2008, 6, 223-238. [CrossRef] [PubMed] 
88. Sever, R.; Glass, C.K. Signaling by nuclear receptors. Cold Spring Harb. Perspect. Biol. 2013, 5, a016709. [CrossRef] [PubMed]

89. Bohn, T.; Desmarchelier, C.; El, S.N.; Keijer, J.; van Schothorst, E.; Rühl, R.; Borel, P. beta-Carotene in the human body: Metabolic bioactivation pathways - from digestion to tissue distribution and excretion. Proc. Nutr. Soc. 2019, 78, 68-87. [CrossRef]

90. Bonet, M.L.; Canas, J.A.; Ribot, J.; Palou, A. Carotenoids and their conversion products in the control of adipocyte function, adiposity and obesity. Arch. Biochem. Biophys. 2015, 572, 112-125. [CrossRef]

91. Le Maire, A.; Alvarez, S.; Shankaranarayanan, P.; Lera, A.R.; Bourguet, W.; Gronemeyer, H. Retinoid receptors and therapeutic applications of RAR/RXR modulators. Curr. Top Med. Chem. 2012, 12, 505-527. [CrossRef]

92. Kroker, A.J.; Bruning, J.B. Review of the structural and dynamic mechanisms of PPAR-gamma partial agonism. PPAR Res. 2015, 2015, 816856. [CrossRef]

93. Aydemir, G.; Kasiri, Y.; Bartok, E.M.; Birta, E.; Fröhlich, K.; Böhm, V.; Mihaly, J.; Rühl, R. Lycopene supplementation restores vitamin A deficiency in mice and possesses thereby partial pro-vitamin A activity transmitted via RAR signaling. Mol. Nutr. Food Res. 2016, 60, 2413-2420. [CrossRef]

94. Carrier, A. Metabolic syndrome and oxidative stress: A complex relationship. AntiOxid. Redox. Signal 2017, 26, 429-431. [CrossRef]

95. Hughes, C.E.; Nibbs, R.J.B. A guide to chemokines and their receptors. FEBS J. 2018, 285, $2944-2971$. [CrossRef]

96. Zhang, J.M.; An, J. Cytokines, inflammation, and pain. Int. Anesthesiol. Clin. 2007, 45, 27-37. [CrossRef] [PubMed]

97. Yoshida, Y.; Umeno, A.; Shichiri, M. Lipid peroxidation biomarkers for evaluating oxidative stress and assessing antioxidant capacity in vivo. J. Clin. Biochem. Nutr. 2013, 52, 9-16. [CrossRef] [PubMed]

98. Schaur, R.J.; Siems, W.; Bresgen, N.; Eckl, P.M. 4-Hydroxy-nonenal-a bioactive lipid peroxidation product. Biomolecules 2015, 5, 2247-2337. [CrossRef]

99. Uchida, K.; Kanematsu, M.; Sakai, K.; Matsuda, T.; Hattori, N.; Mizuno, Y.; Suzuki, D.; Miyata, T.; Noguchi, N.; Niki, E.; et al. Protein-bound acrolein: Potential markers for oxidative stress. Proc. Natl. Acad Sci. USA 1998, 95, 4882-4887. [CrossRef] [PubMed]

100. Griffiths, H.R. Antioxidants and protein oxidation. Free Radic. Res. 2000, 33, S47-S58.

101. Fedorova, M.; Bollineni, R.C.; Hoffmann, R. Protein carbonylation as a major hallmark of oxidative damage: Update of analytical strategies. Mass Spectrom. Rev. 2014, 33, 79-97. [CrossRef] [PubMed]

102. Dalle-Donne, I.; Rossi, R.; Giustarini, D.; Milzani, A.; Colombo, R. Protein carbonyl groups as biomarkers of oxidative stress. Clin. Chim. Acta 2003, 329, 23-38. [CrossRef]

103. Matsumoto, Y.; Ogawa, Y.; Yoshida, R.; Shimamori, A.; Kasai, H.; Ohta, H. The stability of the oxidative stress marker, urinary 8-hydroxy-2'- deoxyguanosine (8-OHdG), when stored at room temperature. J. Occup. Health 2008, 50, 366-372. [CrossRef] [PubMed]

104. Visioli, F.; Bordone, R.; Perugini, C.; Bagnati, M.; Cau, C.; Bellomo, G. The kinetics of copper-induced LDL oxidation depend upon its lipid composition and antioxidant content. BioChem. Biophys. Res. Commun. 2000, 268, 818-822. [CrossRef]

105. Ghaffari, M.A.; Ghiasvand, T. Kinetic study of low density lipoprotein oxidation by copper. Indian J. Clin. Biochem. 2010, 25, 29-36. [CrossRef]

106. Moniruzzaman, M.; Khalil, M.I.; Sulaiman, S.A.; Gan, S.H. Advances in the analytical methods for determining the antioxidant properties of honey: A review. Afr. J. Tradit. Complement. Altern. Med. 2012, 9, 36-42. [CrossRef]

107. Younus, H. Therapeutic potentials of superoxide dismutase. Int. J. Health Sci. 2018, 12, 88-93.

108. Marrocco, I.; Altieri, F.; Peluso, I. Measurement and clinical significance of biomarkers of oxidative stress in humans. Oxid. Med. Cell Longev. 2017, 2017, 6501046. [CrossRef]

109. Lubos, E.; Loscalzo, J.; Handy, D.E. Glutathione peroxidase-1 in health and disease: From molecular mechanisms to therapeutic opportunities. AntiOxid. Redox Signal 2011, 15, 1957-1997. [CrossRef] [PubMed]

110. Sepasi Tehrani, H.; Moosavi-Movahedi, A.A. Catalase and its mysteries. Prog. Biophys. Mol. Biol. 2018, 140, 5-12. [CrossRef] [PubMed]

111. Maritim, A.C.; Sanders, R.A.; Watkins, J.B., 3rd. Diabetes, oxidative stress, and antioxidants: A review. J. Biochem. Mol. Toxicol. 2003, 17, 24-38. [CrossRef] 
112. Bohm, B.; Heinzelmann, S.; Motz, M.; Bauer, G. Extracellular localization of catalase is associated with the transformed state of malignant cells. Biol. Chem. 2015, 396, 1339-1356. [CrossRef]

113. De Jager, W.; Bourcier, K.; Rijkers, G.T.; Prakken, B.J.; Seyfert-Margolis, V. Prerequisites for cytokine measurements in clinical trials with multiplex immunoassays. BMC Immunol. 2009, 10, 52. [CrossRef]

114. Monastero, R.N.; Pentyala, S. Cytokines as biomarkers and their respective clinical cutoff levels. Int. J. Inflamm. 2017, 2017, 4309485. [CrossRef] [PubMed]

115. Mühl, H.; Pfeilschifter, J. Anti-inflammatory properties of pro-inflammatory interferon-gamma. Int. Immunopharmacol. 2003, 3, 1247-1255. [CrossRef]

116. Di Paolo, N.C.; Shayakhmetov, D.M. Interleukin 1alpha and the inflammatory process. Nat. Immunol. 2016, 17, 906-913. [CrossRef]

117. Kenis, G.; Teunissen, C.; De Jongh, R.; Bosmans, E.; Steinbusch, H.; Maes, M. Stability of interleukin 6, soluble interleukin 6 receptor, interleukin 10 and CC16 in human serum. Cytokine 2002, 19, 228-235. [CrossRef]

118. Hunter, C.A.; Jones, S.A. IL-6 as a keystone cytokine in health and disease. Nat. Immunol. 2015, 16, 448-457. [CrossRef]

119. Berry, L.J.; Sheil, B.; Garratt, L.; Sly, P.D.; AREST, C.F. Stability of interleukin 8 and neutrophil elastase in bronchoalveolar lavage fluid following long-term storage. J. Cyst. Fibr. 2010, 9, 346-350. [CrossRef]

120. Turner, M.D.; Nedjai, B.; Hurst, T.; Pennington, D.J. Cytokines and chemokines: At the crossroads of cell signalling and inflammatory disease. Biochim. Biophys. Acta 2014, 1843, 2563-2582. [CrossRef]

121. Doumatey, A.P.; Zhou, J.; Adeyemo, A.; Rotimi, C. High sensitivity C-reactive protein (Hs-CRP) remains highly stable in long-term archived human serum. Clin. Biochem. 2014, 47,315-318. [CrossRef] [PubMed]

122. Sproston, N.R.; Ashworth, J.J. Role of C-reactive protein at sites of inflammation and infection. Front. Immunol. 2018, 9, 754. [CrossRef]

123. Sack, G.H., Jr. Serum amyloid A-A review. Mol. Med. 2018, 24, 46. [CrossRef] [PubMed]

124. Dinarello, C.A. Proinflammatory cytokines. Chest 2000, 118, 503-508. [CrossRef]

125. Alfaro, C.; Sanmamed, M.F.; Rodríguez-Ruiz, M.E.; Teijeira, Á.; Oñate, C.; González, Á.; Ponz, M.; Schalper, K.A.; Pérez-Gracia, J.L.; Melero, I. Interleukin-8 in cancer pathogenesis, treatment and follow-up. Cancer Treat. Rev. 2017, 60, 24-31. [CrossRef] [PubMed]

126. Tanaka, T.; Narazaki, M.; Kishimoto, T. IL-6 in inflammation, immunity, and disease. Cold Spring Harb. Perspect. Biol. 2014, 6, a016295. [CrossRef]

127. Polidori, M.C.; Pratico, D.; Parente, B.; Mariani, E.; Cecchetti, R.; Yao, Y.; Sies, H.; Cao, P.; Mecocci, P.; Stahl, W. Elevated lipid peroxidation biomarkers and low antioxidant status in atherosclerotic patients with increased carotid or iliofemoral intima media thickness. J. Invest. Med. 2007, 55, 163-167. [CrossRef]

128. Martin-Gallan, P.; Carrascosa, A.; Gussinye, M.; Domínguez, C. Biomarkers of diabetes-associated oxidative stress and antioxidant status in young diabetic patients with or without subclinical complications. Free Radic. Biol. Med. 2003, 34, 1563-1574. [CrossRef]

129. Facchini, F.S.; Humphreys, M.H.; DoNascimento, C.A.; Abbasi, F.; Reaven, G.M. Relation between insulin resistance and plasma concentrations of lipid hydroperoxides, carotenoids, and tocopherols. Am. J. Clin. Nutr. 2000, 72, 776-779. [CrossRef]

130. Kisakol, G.; Guney, E.; Bayraktar, F.; Yilmaz, C.; Kabalak, T.; Ozmen, D. Effect of surgical weight loss on free radical and antioxidant balance: A preliminary report. Obes. Surg. 2002, 12, 795-800. [CrossRef]

131. Senthil, S.; Veerappan, R.M.; Ramakrishna Rao, M.; Pugalendi, K.V. Oxidative stress and antioxidants in patients with cardiogenic shock complicating acute myocardial infarction. Clin. Chim Acta 2004, 348, 131-137. [CrossRef] [PubMed]

132. Polidori, M.C.; Praticó, D.; Savino, K.; Rokach, J.; Stahl, W.; Mecocci, P. Increased F2 isoprostane plasma levels in patients with congestive heart failure are correlated with antioxidant status and disease severity. J. Card. Fail. 2004, 10, 334-338. [CrossRef] [PubMed]

133. Serdar, Z.; Serdar, A.; Altin, A.; Eryilmaz, U.; Albayrak, S. The relation between oxidant and antioxidant parameters and severity of acute coronary syndromes. Acta Cardiol. 2007, 62, 373-380. [CrossRef]

134. Chang, C.Y.; Chen, J.Y.; Ke, D.; Hu, M.L. Plasma levels of lipophilic antioxidant vitamins in acute ischemic stroke patients: Correlation to inflammation markers and neurological deficits. Nutrition 2005, 21, 987-993. [CrossRef] 
135. Kataria, Y.; Deaton, R.J.; Enk, E.; Jin, M.; Petrauskaite, M.; Dong, L.; Goldenberg, J.R.; Cotler, S.J.; Jensen, D.M.; van Breemen, R.B.; et al. Retinoid and carotenoid status in serum and liver among patients at high-risk for liver cancer. BMC Gastroenterol. 2016, 16, 30. [CrossRef]

136. Epplein, M.; Franke, A.A.; Cooney, R.V.; Morris, J.S.; Wilkens, L.R.; Goodman, M.T.; Murphy, S.P.; Henderson, B.E.; Kolonel, L.N.; Le Marchand, L. Association of plasma micronutrient levels and urinary isoprostane with risk of lung cancer: The multiethnic cohort study. Cancer Epidemiol. Prev. Biomark. 2009, 18, 1962-1970. [CrossRef]

137. Caliskan-Can, E.; Firat, H.; Ardic, S.; Simşek, B.; Torun, M.; Yardim-Akaydin, S. Increased levels of 8-hydroxydeoxyguanosine and its relationship with lipid peroxidation and antioxidant vitamins in lung cancer. Clin. Chem. Lab. Med. 2008, 46, 107-112. [CrossRef]

138. Tsao, S.M.; Yin, M.C.; Liu, W.H. Oxidant stress and B vitamins status in patients with non-small cell lung cancer. Nutr. Cancer 2007, 59, 8-13. [CrossRef]

139. Almushatat, A.S.; Talwar, D.; McArdle, P.A.; Williamson, C.; Sattar, N.; O’Reilly, D.S.; Underwood, M.A.; McMillan, D.C. Vitamin antioxidants, lipid peroxidation and the systemic inflammatory response in patients with prostate cancer. Int. J. Cancer 2006, 118, 1051-1053. [CrossRef]

140. Roehrs, M.; Valentini, J.; Paniz, C.; Moro, A.; Charão, M.; Bulcão, R.; Freitas, F.; Brucker, N.; Duarte, M.; Leal, M.; et al. The relationships between exogenous and endogenous antioxidants with the lipid profile and oxidative damage in hemodialysis patients. BMC Nephrol. 2011, 12, 59. [CrossRef]

141. Charao, M.F.; Moro, A.M.; Valentini, J.; Brucker, N.; Bubols, G.B.; Bulcão, R.P.; Baierle, M.; Freitas, F.A.; Nascimento, S.N.; Barth, A.; et al. Exogenous and endogenous antioxidants attenuate the lipid peroxidation in workers occupationally exposed to paints. Drug Chem. Toxicol. 2014, 37, 69-75. [CrossRef]

142. Ren, H.; Ghebremeskel, K.; Okpala, I.; Lee, A.; Ibegbulam, O.; Crawford, M. Patients with sickle cell disease have reduced blood antioxidant protection. Int. J. Vitam. Nutr. Res. 2008, 78, 139-147. [CrossRef] [PubMed]

143. Hebbel, R.P.; Eaton, J.W.; Balasingam, M.; Steinberg, M.H. Spontaneous oxygen radical generation by sickle erythrocytes. J. Clin. Invest. 1982, 70, 1253-1259. [CrossRef] [PubMed]

144. Maor, I.; Rainis, T.; Lanir, A.; Lavy, A. Oxidative stress, inflammation and neutrophil superoxide release in patients with Crohn's disease: Distinction between active and non-active disease. Dig. Dis. Sci. 2008, 53, 2208-2214. [CrossRef] [PubMed]

145. Cemek, M.; Dede, S.; Bayiroglu, F.; Caksen, H.; Cemek, F.; Yuca, K. Oxidant and antioxidant levels in children with acute otitis media and tonsillitis: A comparative study. Int. J. Pediatr. Otorhinolaryngol. 2005, 69, 823-827. [CrossRef] [PubMed]

146. Bouayed, J.; Bohn, T. Exogenous antioxidants—Double-edged swords in cellular redox state: Health beneficial effects at physiologic doses versus deleterious effects at high doses. Oxid. Med. Cell Longev. 2010, 3, 228-237. [CrossRef] [PubMed]

147. Haldar, S.; Rowland, I.R.; Barnett, Y.A.; Bradbury, I.; Robson, P.J.; Powell, J.; Fletcher, J. Influence of habitual diet on antioxidant status: A study in a population of vegetarians and omnivores. Eur. J. Clin. Nutr. 2007, 61, 1011-1022. [CrossRef] [PubMed]

148. Kim, Y.; Kim, Y.J.; Lim, Y.; Oh, B.; Kim, J.Y.; Bouwman, J.; Kwon, O. Combination of diet quality score, plasma carotenoids, and lipid peroxidation to monitor oxidative stress. Oxid. Med. Cell Longev. 2018, 2018, 8601028. [CrossRef] [PubMed]

149. Orhon, F.S.; Ulukol, B.; Kahya, D.; Cengiz, B.; Başkan, S.; Tezcan, S. The influence of maternal smoking on maternal and newborn oxidant and antioxidant status. Eur. J. Pediatr. 2009, 168, 975-981. [CrossRef] [PubMed]

150. Suwannalert, P.; Boonsiri, P.; Khampitak, T.; Khampitak, K.; Sriboonlue, P.; Yongvanit, P. The levels of lycopene, alpha-tocopherol and a marker of oxidative stress in healthy northeast Thai elderly. Asia Pac. J. Clin. Nutr. 2007, 16 Suppl 1, 27-30. [PubMed]

151. Zhou, Y.E.; Buchowski, M.S.; Liu, J.; Schlundt, D.G.; Ukoli, F.; Blot, W.J.; Hargreaves, M.K. Plasma lycopene is associated with pizza and pasta consumption in middle-aged and older african american and white adults in the southeastern USA in a cross-sectional study. PLoS ONE 2016, 11, e0161918. [CrossRef]

152. Rink, S.M.; Mendola, P.; Mumford, S.L.; Poudrier, J.K.; Browne, R.W.; Wactawski-Wende, J.; Perkins, N.J.; Schisterman, E.F. Self-report of fruit and vegetable intake that meets the 5 a day recommendation is associated with reduced levels of oxidative stress biomarkers and increased levels of antioxidant defense in premenopausal women. J. Acad. Nutr. Diet. 2013, 113, 776-785. [CrossRef] 
153. Weber, D.; Stuetz, W.; Toussaint, O.; Debacq-Chainiaux, F.; Dollé, M.E.T.; Jansen, E.; Gonos, E.S.; Franceschi, C.; Sikora, E.; Hervonen, A.; et al. Associations between specific redox biomarkers and age in a large European cohort: The MARK-AGE project. Oxid. Med. Cell Longev. 2017, 2017, 1401452. [CrossRef]

154. Parfitt, V.J.; Rubba, P.; Bolton, C.; Marotta, G.; Hartog, M.; Mancini, M. A comparison of antioxidant status and free radical peroxidation of plasma lipoproteins in healthy young persons from Naples and Bristol. Eur. Heart J. 1994, 15, 871-876. [CrossRef]

155. Pincemail, J.; Vanbelle, S.; Gaspard, U.; Collette, G.; Haleng, J.; Cheramy-Bien, J.P.; Charlier, C.; Chapelle, J.P.; Giet, D.; Albert, A.; et al. Effect of different contraceptive methods on the oxidative stress status in women aged 4048 years from the ELAN study in the province of liege, belgium. Hum. Reprod. 2007, 22, 2335-2343. [CrossRef] [PubMed]

156. Mazereeuw, G.; Herrmann, N.; Andreazza, A.C.; Khan, M.M.; Lanctôt, K.L. A meta-analysis of lipid peroxidation markers in major depression. Neuropsychiatr. Dis. Treat. 2015, 11, 2479-2491. [PubMed]

157. Tsuboi, H.; Shimoi, K.; Kinae, N.; Oguni, I.; Hori, R.; Kobayashi, F. Depressive symptoms are independently correlated with lipid peroxidation in a female population: Comparison with vitamins and carotenoids. J. Psychosom. Res. 2004, 56, 53-58. [CrossRef]

158. Berr, C.; Richard, M.J.; Roussel, A.M.; Bonithon-Kopp, C. Systemic oxidative stress and cognitive performance in the population-based EVA study. Etude du vieillissement arteriel. Free Radic. Biol. Med. 1998, 24, 1202-1208. [CrossRef]

159. Rehman, K.; Akash, M.S.H. Mechanism of generation of oxidative stress and pathophysiology of type 2 diabetes mellitus: How are they interlinked? J. Cell Biochem. 2017, 118, 3577-3585. [CrossRef]

160. Gill, J.G.; Piskounova, E.; Morrison, S.J. Cancer, oxidative stress, and metastasis. Cold Spring Harb. Symp. Quant. Biol. 2016, 81, 163-175. [CrossRef] [PubMed]

161. Hamer, M.; Chida, Y. Intake of fruit, vegetables, and antioxidants and risk of type 2 diabetes: Systematic review and meta-analysis. J. Hypertens. 2007, 25, 2361-2369. [CrossRef]

162. Shardell, M.D.; Alley, D.E.; Hicks, G.E.; Etl-Kamary, S.S.; Miller, R.R.; Semba, R.D.; Ferrucci, L. Low-serum carotenoid concentrations and carotenoid interactions predict mortality in US adults: The third national health and nutrition examination survey. Nutr. Res. 2011, 31, 178-189. [CrossRef]

163. Zhao, L.G.; Zhang, Q.L.; Zheng, J.L.; Li, H.L.; Zhang, W.; Tang, W.G.; Xiang, Y.B. Dietary, circulating beta-carotene and risk of all-cause mortality: A meta-analysis from prospective studies. Sci. Rep. 2016, 6, 26983. [CrossRef]

164. Huang, J.; Weinstein, S.J.; Yu, K.; Männistö, S.; Albanes, D. Serum beta carotene and overall and cause-specific mortality. Circ. Res. 2018, 123, 1339-1349. [CrossRef]

165. Besler, H.T.; Comoglu, S.; Okcu, Z. Serum levels of antioxidant vitamins and lipid peroxidation in multiple sclerosis. Nutr. Neurosci. 2002, 5, 215-220. [CrossRef] [PubMed]

166. Codoner-Franch, P.; Pons-Morales, S.; Boix-Garcia, L.; Valls-Bellés, V. Oxidant/antioxidant status in obese children compared to pediatric patients with type 1 diabetes mellitus. Pediatr. Diabetes 2010, 11, 251-257. [CrossRef] [PubMed]

167. Polidori, M.C.; Savino, K.; Alunni, G.; Freddio, M.; Senin, U.; Freddio, M.; Senin, U.; Sies, H.; Stahl, W.; Mecocci, P. Plasma lipophilic antioxidants and malondialdehyde in congestive heart failure patients: Relationship to disease severity. Free Radic. Biol. Med. 2002, 32, 148-152. [CrossRef]

168. Naziroglu, M.; Kokcam, I.; Simsek, H.; Karakılçık, A.; Naziroğlu, M. Lipid peroxidation and antioxidants in plasma and red blood cells from patients with pemphigus vulgaris. J. Basic Clin. Physiol Pharmacol. 2003, 14, 31-42. [CrossRef] [PubMed]

169. Bohn, T. Bioavailabilty of non-provitamin A carotenoids. Curr. Nutr. Food Sci. 2008, 4, 240-258. [CrossRef]

170. Bohn, T. Provitamin A carotenoids-Occurrence, intake, and bioavailability. In Vitamin A and Carotenoids: Chemistry, Analysis, Function and Effects (Food and Nutritional Components in Focus); Preedy, V., Ed.; RSC Publishing: London, UK, 2012.

171. Winklhofer-Roob, B.M.; Puhl, H.; Khoschsorur, G.; Hof, M.A.V.; Esterbauer, H.; Shmerling, D.H. Enhanced resistance to oxidation of low density lipoproteins and decreased lipid peroxide formation during beta-carotene supplementation in cystic fibrosis. Free Radic. Biol. Med. 1995, 18, 849-859. [CrossRef]

172. Renner, S.; Rath, R.; Rust, P.; Lehr, S.; Frischer, T.; Elmadfa, I.; Eichler, I. Effects of beta-carotene supplementation for six months on clinical and laboratory parameters in patients with cystic fibrosis. Thorax 2001, 56, 48-52. [CrossRef] [PubMed] 
173. Levy, Y.; Zaltsberg, H.; Ben-Amotz, A.; Levy, Y.; Aviram, M. Dietary supplementation of a natural isomer mixture of beta-carotene inhibits oxidation of LDL derived from patients with diabetes mellitus. Ann. Nutr. Metab. 2000, 44, 54-60. [CrossRef] [PubMed]

174. Allard, J.P.; Royall, D.; Kurian, R.; Muggli, R.; Jeejeebhoy, K.N. Effects of beta-carotene supplementation on lipid peroxidation in humans. Am. J. Clin. Nutr. 1994, 59, 884-890. [CrossRef] [PubMed]

175. Kim, J.H.; Chang, M.J.; Choi, H.D.; Youn, Y.K.; Kim, J.T.; Oh, J.M. Protective effects of Haematococcus astaxanthin on oxidative stress in healthy smokers. J. Med. Food 2011, 14, 1469-1475. [CrossRef] [PubMed]

176. Naguib, Y.M. Antioxidant activities of astaxanthin and related carotenoids. J. Agric. Food Chem. 2000, 48, 1150-1154. [CrossRef] [PubMed]

177. Hininger, I.; Chopra, M.; Thurnham, D.I.; Laporte, F.; Richard, M.J.; Favier, A.; Roussel, A.M. Effect of increased fruit and vegetable intake on the susceptibility of lipoprotein to oxidation in smokers. Eur. J. Clin. Nutr. 1997, 51, 601-606. [CrossRef] [PubMed]

178. Ademowo, O.S.; Dias, H.K.I.; Milic, I.; Devitt, A.; Moran, R.; Mulcahy, R.; Howard, A.; Nolan, J.; Griffiths, H.; Dias, I. Phospholipid oxidation and carotenoid supplementation in Alzheimer's disease patients. Free Radic. Biol. Med. 2017, 108, 77-85. [CrossRef] [PubMed]

179. Souci, S.W.; Fachmann, W.; Kraut, H. Food Compoisition and Nutrition Tables; CRC press: Boca Raton, FL, USA, 2000; Volume 6.

180. Catanzaro, R.; Zerbinati, N.; Solimene, U.; Marcellino, M.; Mohania, D.; Italia, A.; Ayala, A.; Marotta, F. Beneficial effect of refined red palm oil on lipid peroxidation and monocyte tissue factor in HCV-related liver disease: A randomized controlled study. Hepatobiliary Pancreat Dis. Int. 2016, 15, 165-172. [CrossRef]

181. Sarkar, P.D.; Gupt, T.; Sahu, A. Comparative analysis of lycopene in oxidative stress. J. Assoc. Physicians India 2012, 60, 17-19. [PubMed]

182. Bose, K.S.; Agrawal, B.K. Effect of lycopene from tomatoes (cooked) on plasma antioxidant enzymes, lipid peroxidation rate and lipid profile in grade-I hypertension. Ann. Nutr. Metab. 2007, 51, 477-481. [CrossRef]

183. Giovannucci, E. Commentary: Serum lycopene and prostate cancer progression: A re-consideration of findings from the prostate cancer prevention trial. Cancer Causes Control 2011, 22, 1055-1059. [CrossRef] [PubMed]

184. Giovannucci, E.; Liu, Y.; Platz, E.A.; Stampfer, M.J.; Willett, W.C. Risk factors for prostate cancer incidence and progression in the health professionals follow-up study. Int. J. Cancer 2007, 121, 1571-1578. [CrossRef]

185. Van Breemen, R.B.; Sharifi, R.; Viana, M.; Pajkovic, N.; Zhu, D.; Yuan, L.; Yang, Y.; Bowen, P.E.; Stacewicz-Sapuntzakis, M. Antioxidant effects of lycopene in African American men with prostate cancer or benign prostate hyperplasia: A randomized, controlled trial. Cancer Prev. Res. 2011, 4, 711-718. [CrossRef]

186. Elmadfa, I.; Rust, P.; Majchrzak, D.; Wagner, K.H.; Genser, D.; Lettner, R.; Pinter, M. Effects of beta-carotene supplementation on free radical mechanism in healthy adult subjects. Int. J. Vitam. Nutr. Res. 2004, 74, 147-152. [CrossRef]

187. Mobarhan, S.; Bowen, P.; Andersen, B.; Evans, M.; Stacewicz-Sapuntzakis, M.; Sugerman, S.; Simms, P.; Lucchesi, D.; Friedman, H. Effects of beta-carotene repletion on beta-carotene absorption, lipid peroxidation, and neutrophil superoxide formation in young men. Nutr. Cancer 1990, 14, 195-206. [CrossRef] [PubMed]

188. Kawashima, A.; Madarame, T.; Koike, H.; Komatsu, Y.; Wise, J.A. Four week supplementation with mixed fruit and vegetable juice concentrates increased protective serum antioxidants and folate and decreased plasma homocysteine in Japanese subjects. Asia Pac. J. Clin. Nutr. 2007, 16, 411-421. [PubMed]

189. Hininger, I.A.; Meyer-Wenger, A.; Moser, U.; Wright, A.; Southon, S.; Thurnham, D.; Chopra, M.; Berg, H.V.D.; Olmedilla, B.; Favier, A.E.; et al. No significant effects of lutein, lycopene or beta-carotene supplementation on biological markers of oxidative stress and LDL oxidizability in healthy adult subjects. J. Am. Coll. Nutr. 2001, 20, 232-238. [CrossRef] [PubMed]

190. Wang, M.X.; Jiao, J.H.; Li, Z.Y.; Liu, R.-R.; Shi, Q.; Ma, L. Lutein supplementation reduces plasma lipid peroxidation and C-reactive protein in healthy nonsmokers. Atherosclerosis 2013, 227, 380-385. [CrossRef] [PubMed]

191. Perrone, S.; Tei, M.; Longini, M.; Santacroce, A.; Turrisi, G.; Proietti, F.; Felici, C.; Picardi, A.; Bazzini, F.; Vasarri, P.; et al. Lipid and protein oxidation in newborn infants after lutein administration. Oxid. Med. Cell Longev. 2014, 2014, 781454. [CrossRef] [PubMed] 
192. Perrone, S.; Longini, M.; Marzocchi, B.; Picardi, A.; Bellieni, C.V.; Proietti, F.; Rodriguez, A.; Turrisi, G.; Buonocore, G. Effects of lutein on oxidative stress in the term newborn: A pilot study. Neonatology 2010, 97, 36-40. [CrossRef] [PubMed]

193. Rubin, L.P.; Chan, G.M.; Barrett-Reis, B.M.; Fulton, A.B.; Hansen, R.M.; Ashmeade, T.L.; Oliver, J.S.; Mackey, A.D.; Dimmit, R.A.; Hartmann, E.E.; et al. Effect of carotenoid supplementation on plasma carotenoids, inflammation and visual development in preterm infants. J. Perinatol. 2011, 32, 418-424. [CrossRef]

194. Miyazawa, T.; Nakagawa, K.; Takekoshi, H.; Higuchi, O.; Kato, S.; Kondo, M.; Kimura, F.; Miyazawa, T. Ingestion of chlorella reduced the oxidation of erythrocyte membrane lipids in senior Japanese subjects. J. Oleo. Sci. 2013, 62, 873-881. [CrossRef]

195. Nakagawa, K.; Kiko, T.; Miyazawa, T.; Kimura, F.; Satoh, A.; Miyazawa, T. Antioxidant effect of astaxanthin on phospholipid peroxidation in human erythrocytes. Br. J. Nutr. 2011, 105, 1563-1571. [CrossRef]

196. Devaraj, S.; Mathur, S.; Basu, A.; Aung, H.H.; Vasu, V.T.; Meyers, S.; Jialal, I. A dose-response study on the effects of purified lycopene supplementation on biomarkers of oxidative stress. J. Am. Coll. Nutr. 2008, 27, 267-273. [CrossRef]

197. Briviba, K.; Bub, A.; Moseneder, J.; Schwerdtle, T.; Hartwig, A.; Kulling, S.E.; Watzl, B. No differences in DNA damage and antioxidant capacity between intervention groups of healthy, nonsmoking men receiving 2, 5, or 8 servings/day of vegetables and fruit. Nutr. Cancer 2008, 60, 164-170. [CrossRef] [PubMed]

198. Misra, R.; Mangi, S.; Joshi, S.; Mittal, S.; Gupta, S.K.; Pandey, R.M. LycoRed as an alternative to hormone replacement therapy in lowering serum lipids and oxidative stress markers: A randomized controlled clinical trial. J. Obstet. Gynaecol. Res. 2006, 32, 299-304. [CrossRef] [PubMed]

199. Engelhard, Y.N.; Gazer, B.; Paran, E. Natural antioxidants from tomato extract reduce blood pressure in patients with grade-1 hypertension: A double-blind, placebo-controlled pilot study. Am. Heart J. 2006, 151, 100. [CrossRef] [PubMed]

200. Mackinnon, E.S.; Rao, A.V.; Rao, L.G. Dietary restriction of lycopene for a period of one month resulted in significantly increased biomarkers of oxidative stress and bone resorption in postmenopausal women. J. Nutr. Health Aging 2011, 15, 133-138. [CrossRef]

201. Pandey, K.B.; Rizvi, S.I. Anti-oxidative action of resveratrol: Implications for human health. Arab. J. Chem. 2011, 4, 293-298. [CrossRef]

202. Jowko, E.; Dlugolecka, B.; Makaruk, B.; Cieśliński, I. The effect of green tea extract supplementation on exercise-induced oxidative stress parameters in male sprinters. Eur. J. Nutr. 2015, 54, 783-791. [CrossRef] [PubMed]

203. Minzanova, T.S.; Mironov, F.V.; Arkhipova, M.D.; Khabibullina, A.V.; Mironova, L.G.; Zakirova, Y.M.; Milyukov, V.A. Biological activity and pharmacological application of pectic polysaccharides: A review. Polymers 2018, 10, 1407. [CrossRef]

204. Haegele, A.D.; Gillette, C.; O’Neill, C.; Wolfe, P.; Heimendinger, J.; Sedlacek, S.; Thompson, H.J. Plasma xanthophyll carotenoids correlate inversely with indices of oxidative DNA damage and lipid peroxidation. Cancer Epidemiol. Biomark. Prev. 2000, 9, 421-425.

205. Thompson, H.J.; Heimendinger, J.; Diker, A.; Meinecke, B.; Wolfe, P.; Zhu, Z.; Heimendinger, J.; Diker, A.; Sedlacek, S.; Jiang, W. Dietary botanical diversity affects the reduction of oxidative biomarkers in women due to high vegetable and fruit intake. J. Nutr. 2006, 136, 2207-2212. [CrossRef]

206. The Alpha-tocopherol Beta-Carotene Cancer Prevention Group. The effect of vitamin E and beta carotene on the incidence of lung cancer and other cancers in male smokers. The alpha-tocopherol, beta carotene cancer prevention study group. N Engl. J. Med. 1994, 330, 1029-1035. [CrossRef]

207. Druesne-Pecollo, N.; Latino-Martel, P.; Norat, T.; Barrandon, E.; Bertrais, S.; Galan, P.; Hercberg, S. Beta-carotene supplementation and cancer risk: A systematic review and metaanalysis of randomized controlled trials. Int. J. Cancer 2010, 127, 172-184. [CrossRef]

208. Hennekens, C.H.; Buring, J.E.; Manson, J.E.; Stampfer, M.; Rosner, B.; Cook, N.R.; Belanger, C.; LaMotte, F.; Gaziano, J.M.; Ridker, P.M.; et al. Lack of effect of long-term supplementation with beta carotene on the incidence of malignant neoplasms and cardiovascular disease. N Engl. J. Med. 1996, 334, 1145-1149. [CrossRef] [PubMed] 
209. Heart Protection Study Collaborative Group. MRC/BHF heart protection study of antioxidant vitamin supplementation in 20,536 high-risk individuals: A randomised placebo-controlled trial. Lancet 2002, 360, 23-33. [CrossRef]

210. Blot, W.J.; Li, J.Y.; Taylor, P.R.; Guo, W.; Dawsey, S.M.; Li, B. The Linxian trials: Mortality rates by vitamin-mineral intervention group. Am. J. Clin. Nutr. 1995, 62, 1424S-1426S. [CrossRef] [PubMed]

211. Bjelakovic, G.; Nikolova, D.; Gluud, L.L.; Simonetti, R.G.; Gluud, C. Antioxidant supplements for prevention of mortality in healthy participants and patients with various diseases. Cochrane Database Syst. Rev. 2012, 14, Cd007176. [CrossRef]

212. Xu, X.R.; Zou, Z.Y.; Xiao, X.; Huang, Y.M.; Wang, X.; Lin, X.M. Effects of lutein supplement on serum inflammatory cytokines, ApoE and lipid profiles in early atherosclerosis population. J. Atheroscler. Thromb. 2013, 20, 170-177. [CrossRef] [PubMed]

213. McEneny, J.; Wade, L.; Young, I.S.; Masson, L.; Duthie, G.; McGinty, A.; McMaster, C.; Thies, F. Lycopene intervention reduces inflammation and improves HDL functionality in moderately overweight middle-aged individuals. J. Nutr. Biochem. 2013, 24, 163-168. [CrossRef]

214. Riso, P.; Visioli, F.; Grande, S.; Guarnieri, S.; Gardana, C.; Simonetti, P.; Porrini, M. Effect of a tomato-based drink on markers of inflammation, immunomodulation, and oxidative stress. J. Agric. Food Chem. 2006, 54, 2563-2566. [CrossRef]

215. Biddle, M.J.; Lennie, T.A.; Bricker, G.V.; Kopec, R.E.; Schwartz, S.J.; Moser, D.K. Lycopene dietary intervention: A pilot study in patients with heart failure. J. Cardiovasc. Nurs. 2015, 30, 205-212. [CrossRef]

216. Watzl, B.; Bub, A.; Blockhaus, M.; Herbert, B.M.; Lührmann, P.M.; Neuhäuser-Berthold, M.; Rechkemmer, G. Prolonged tomato juice consumption has no effect on cell-mediated immunity of well-nourished elderly men and women. J. Nutr. 2000, 130, 1719-1723. [CrossRef]

217. Lee, C. Collaborative power of Nrf2 and PPARgamma activators against metabolic and drug-induced oxidative injury. Oxid. Med. Cell Longev. 2017, 2017, 1378175. [CrossRef] [PubMed]

218. Zhang, X.; Zhao, W.E.; Hu, L.; Zhao, L.; Huang, J. Carotenoids inhibit proliferation and regulate expression of peroxisome proliferators-activated receptor gamma (PPARgamma) in K562 cancer cells. Arch. Biochem. Biophys. 2011, 512, 96-106. [CrossRef] [PubMed]

(C) 2019 by the author. Licensee MDPI, Basel, Switzerland. This article is an open access article distributed under the terms and conditions of the Creative Commons Attribution (CC BY) license (http://creativecommons.org/licenses/by/4.0/). 